\title{
Studies on the protective components in a ribonuclease sensitive ribosomal vaccine of pseudomonas aeruginosa
}

Citation for published version (APA):

Kolfschoten-Gonggrijp, R. (1982). Studies on the protective components in a ribonuclease sensitive ribosomal vaccine of pseudomonas aeruginosa. [Doctoral Thesis, Maastricht University]. Rijksuniversiteit Limburg. https://doi.org/10.26481/dis.19820101rk

Document status and date:

Published: 01/01/1982

DOI:

10.26481/dis.19820101rk

Document Version:

Publisher's PDF, also known as Version of record

Please check the document version of this publication:

- A submitted manuscript is the version of the article upon submission and before peer-review. There can be important differences between the submitted version and the official published version of record.

People interested in the research are advised to contact the author for the final version of the publication, or visit the DOI to the publisher's website.

- The final author version and the galley proof are versions of the publication after peer review.

- The final published version features the final layout of the paper including the volume, issue and page numbers.

Link to publication

\footnotetext{
General rights rights.

- You may freely distribute the URL identifying the publication in the public portal. please follow below link for the End User Agreement:

www.umlib.nl/taverne-license

Take down policy

If you believe that this document breaches copyright please contact us at:

repository@maastrichtuniversity.nl

providing details and we will investigate your claim.
}

Copyright and moral rights for the publications made accessible in the public portal are retained by the authors and/or other copyright owners and it is a condition of accessing publications that users recognise and abide by the legal requirements associated with these

- Users may download and print one copy of any publication from the public portal for the purpose of private study or research.

- You may not further distribute the material or use it for any profit-making activity or commercial gain

If the publication is distributed under the terms of Article $25 \mathrm{fa}$ of the Dutch Copyright Act, indicated by the "Taverne" license above, 
Promotor : Prof.Dr. C.P.A. van Boven

Referenten : Prof.Dr.P.J.C. van Breda Vriesman

Prof.Dr. G. Kootstra

Prof.Dr. M.F. Michel

Prof.Dr. J.M.N. Willers 

aan mijn ouders

aan Richard 


\section{contents.}

Chapter I : Introduction.

Chapter II : Ribosomal vaccines and the nature of their pro- 5 tective components.

Chapter III : Pseudomonas aeruginosa: virulence and vaccines.

Chapter IV : Ribonuclease-sensitive ribosomal vaccine of 37 Pseudomonas aeruginosa.

Chapter $V$ : Evidence for the presence of Iipopolysaccharide in a ribonuclease-sensitive ribosomal vaccine of Pseudomonas aeruginosa.

Chapter VI : Serotype-nonspecific protection induced by ribonucleic acid isolated from the ribosomal vaccine of Pseudomonas aeruqinosa.

Chapter VII : Protection induced by ribosomal ribonucleic acid 63 of Pseudomonas aeruginosa not due to contaminating lipopolysaccharide.

Chapter VIII : Studies on the mechanism of nonspecific protection 81 induced by ribosomal ribonucleic acid of Pseudomonas aeruginosa and the adjuvant dimethyldioctadecylammonium bromide.

Chapter IX : General discussion. 101

Summary. 109

Samenvatting. 115

Dankwoord. 121

Curriculum vitae. 

5 


\section{Introduction.}

The principles of vaccination were based on the observation that individuals who recovered from certain diseases did not become ill when they were exposed to the same disease again. At the end of the eightteenth century Jenner introduced the vaccination with cowpox since he abserved that infection with cowpox protected individuals against smallpox. The preparation and application of the first vaccines was largely based on trial and error. Intensive research on the pathogenic mechanism of the infectious agents and on the fundamentals of immunology permitted the development of vaccination as one of the most important tools in the prevention of infectious diseases all over the world.

The first vaccines contained either detoxified toxins of bacteria or living, attenuated microorganisms which were antigenically equal or closely related to the pathogenic microorganism while their virulence was significantly reduced. Apparently such vaccines could induce a specific resistance ("immunity") against the related pathogen. However, the injection of living attenuated inicroorganisms was not without risk. Subsequent experiments demonstrated that killed microorganisms, or even fragments of them could also be used as a vaccine when the proper antigens were preserved.

However, for some pathogens efforts to prepare vaccines from killed organisms remained unavailing. This was in particular true for microorganisms which behaved like intracellular parasites in the host. One example of such a microorganism was Mycobacterium tuberculosis. Youmans and Youmans (20) developed the hypothesis that a labile component of $M$. tuberculosis was required for the induction of protective immunity. This component might easily be destroyed when the bacteria were killed. Fractionation of living mycobacteria under mild conditions yielded a protective fraction which was rich in ribosomes. The protective activity of this ribosomal vaccine was reduced after enzymatic digestion of the ribonucleic acid (RNA) with ribonuclease (RNase). Further studies convinced Youmans and Youmans (20) that in Mycobacterium tuberculosis ribosomal RNA was the labile component responsible for the jnduction of immunity.

However, this conclusion conflicted with the generally accepted concept that immunity results from the recognition of the outside of an invading microorganism by lymphocytes which have been 
"primed" earlier by contact with the cell envelope antigens. The ribosomal RNA was hidden in the tubercle bacil and it was unclear how this RNA could induce immunity against a subsequent challenge with intact mycobacteria.

Since the first publications of Youmans and Youmans ribosomal vaccines have been prepared from many different microorganisms (6), significant protection could be induced with all the ribosomal vaccines except for a ribosomal preparation of Yersinia pestis (11). Some ribosomal vaccines had remarkable advantages over the more "conventional" vaccines of the same microorganism. Ribosomal vaccines are generally considered to be relatively non toxic, and the induction of cross serotype protection has been reported (19). However, studies concerning the nature of the protective components in these vaccines yielded confusing results. Only a few of the various ribosomal vaccines appeared to be sensitive to RNase. The different opinions about the nature of the protective components in the ribosomal vaccines have been concentrated on three alternatives. Firstly, the protective activity of a ribosomal preparation could entirely be due to contaminating cell envelope antigens $(3,5,10)$. Secondly, the ribosomes (or ribosomal components) might function as carrier or adjuvant in the presentation of cell envelope components. And thirdly, ribosomes or ribosomal components could be responsible for the protective activity of a ribosomal vaccine. Although many recent reports support the first explanation $(3,7,13,17)$ the discussion on the nature of the protective components in ribosomal vaccines has not yet been finished.

Pseudomonas aeruginosa is not pathogenic for healthy individuals. However, for the immunocompromised hosts in the hospital environment $P$. aeruginosa infection is often a life threatening problem. In particular patients with extensive burns (15), cancer patients (18) and patients with cystic fibrosis (9) are susceptible to pseudomonas septicemia. Only few antibiotics are available for therapy of pseudomonas septicemia and their value in the treatment of pseudomonas bacteremia is open to question $(2,4)$. Moreover, P. aeruginosa is a versatile microorganism which easily becomes resistant against the drugs used $(4,16)$. Recentiy vaccines of $P$. aeruginosa have been developed for application in humens $(1,8,12)$. These vaccines contained cel1 envelope antigens, principally lipopolysaccharide (LPS) which bears the serotype specific 0 antigens. Two problems have hampered the application of these vaccines. Firstly, the toxicity of LPS for the human body an the frequent adverse side effects have necessitated the reduction of the dose of a pseudomonas vaccine and the number of injections in patients with cancer (14). Secondly, these vaccines had to be polyvalent, i.e. LPS of all the prevalent serotypes of $P$. aeruginosa had to be included in the vaccine. 
Therefore a ribosomal vaccine of $P$. aeruginosa might have

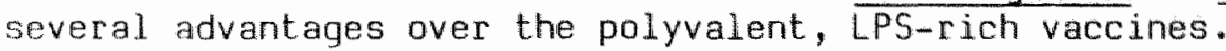

The aim of this study is to prepare a ribosomal vaccine of $P$. aeruginosa and to determine its protection inducing capacity, the nature of the protective components in the vaccine, and the mechanism whereby the protection is exerted.

A review of the literature concerning ribosomal vaccines is presented in chapter 2 of this thesis. Chapter 3 deals with the current knowledge of the virulence factors of $P$. aeruginosa and the experiences with several vaccines of this microorganism. In the chapters 4 up to 8 our experimental wark on the ribosomal vaccine of $P$. aeruginosa is presented. In chapter 4 the purification and chemical characterization of the ribosomal vaccine of $P$. aeruginosa is described and its sensitivity to ribonuclease is demonstrated. The contribution of contaminating LPS in the ribosomal vaccine to its protective activity is analysed in chapter 5 , while the contribution of ribosomal vaccine is demonstrated in chapter 6 . In chapter 7 the possibility that the protective activity of the RNA preparation might be due to LPS or fragments of LPS is excluded. Chapter 8 contains studies on the mechanism of the nonspecific protection induced by RNA. A general discussion is given in chapter 9.

\section{LITERATURE.}

1. Alexander, J.W. and M.W. Fisher. 1974. Immunization against pseudomonas infection after thermal injury. J. Infect. Dis. 130 5: $152-158$.

2. Andriole, V.T. 1979. Pseudomonas bacteremia: Can antibiotic therapy improve survival? J. Lab. Clin. Med. 94: 196-200.

3. Au, C.C. and T.K. Eisenstein. 1981. Nature of the crossprotective antigen in subcellular vaccines of Streptococcus pneumoniae. Infect. Immun. 1981: 160-168.

4. Baltch, A.L., M. Hammer, R.P. Smith and N. Sutphen. 1979. Pseudomonas aeruginosa bacteremia. Susceptibility of 100 blood culture isolates to seven antimicrobial agents and its clinical significance. J. Lab. Clin. Med. 94: 196-200.

5. Eisenstein, T.K. 1974. Evidence for 0 antigens as the antigenic determinants in "ribosomal" vaccines prepared from salmonella. Infect. Immun. 12: 364-377.

6. Eisenstein, T.K. 1978. Ribosomal "vaccines": a review. p. 211-222. In A. Voller and H. Friedman (eds.), New Trends and Developments in Vaccines. MTP Press, Saint Leonard's Gate, Lancaster.

7. Field, L.H., C.D. Parker, C.R. Manclark and L.J. Berry. 1979. Evaluation of a ribosomal vaccine against pertussis. Infect. Immun. 24: 346-351. 
B. Hanessian, S., W. Regan, D. Watson and T.H. Haskel1. 1971. Isolation and characterization of antigenic components of a new heptavalent pseudomonas vaccine. Nature 229: 209-210.

9. Huan, N.N. and R.G. Doggett. 1979. Antibiatic therapy of pseudomonas infection in patients with cystic fibrosis. In R.G. Daggett (ed.), Pseudomonas aeruginosa. Clinical manifestations of infections and current therapy. Academic Press Inc., New York.

10. Jensen, R., B. Cregory, J. Naylor and P. Actor. 1972. Isolation of protective somatic antigen from Vibrio cholerae (Ogawa) ribasomal preparations. Infect. Immun. 6: 156-161.

11. Johnson, W. 1972. Ribosomal vaccines. I. Immunogenicity of ribosomal fractions isolated from Salmonella typhimurium and Yersinia pestis. Infect. Immun. 5: 947-952.

12. Jones, R.J., E.A. Roe, E.J.L. Lowbury, J.J. Miller and J.F. Spilsbury. 1976. A new pseudomonas vaccine: preliminary trial on human volunteers. J. Hyg. 76: 429-439.

13. Misfeldt, M.L., and W. Johnson. 1978. Protective ability of salmonella ribosomal protein and RNA in inbred mice. Infect. Immun. 21: 286-291.

14. Pennington, J.E., H.J. Reynolds, R.E. Wood, R.A. Robinson and A.S. Levine. 1975. Use of a Pseudomonas aeruqinosa vaccine in patients with acute leukemia and cystic fibrosis. Am. J. Med. $58: 629-636$.

15. Pruitt, B.A. and R.B. Lindberg. 1979. Pseudomonas aeruginosa infections in burn patients. In R.G. Doggett (ed.), Pseudomonas aeruginosa. Clinical manifestations of infection and current therapy. Academic Press Inc., New York.

16. Richmond, M.H. 1975. Antibiotic inactivation and its genetic basis, p. 1-33. In M.R.W. Brown (ed.), Resistance of Pseudomonas aeruginosa. John Wiley and Sons, London.

17. Riottot, M.M., J.M. Fournier and H. Jouin. 1981. Direct evidence for the involvement of capsular polysaccharide in the immunoprotective activity of Klebsiella pneumoniae ribosomal preparations. Infect. Immun. 31: 71-77.

18. Rodríguez, V. and G.P. Bodey. 1979. Epidemiology, clinical manifestations and treatment in cancer patients. In R.G. Doggett (ed.), Pseudomonas aeruqinosa. Clinical manifestations of infections and current therapy. Academic Press Inc., New York.

19. Thompsan, H.C.W. and J.S. Snijder. 1971. Protection against pheumococcal infection by a ribosonal preparation. Infect. Immurn. 3: 16-23.

20. Youmans, A.S. and G.P. Youmans, 1975. Mycobacterial extracts and immunity to tuberculosis, p. 399-410. In E. Neter and F. Milgrom (eds.), The inmune system and infectious diseases. Fourth International Convocation on Immunology, Buffalo, N.Y. 1974. S. Karger AG Verlag, Basel. 


\title{
Chapter 2
}

\section{Ribosomal vaccines and the nature of their protective components.}

\author{
INTRODUCTION
}

Youmans and Youmans (51) were the first to report that ribosome rich preparations of Mycabacterium tuberculosis were effective vaccines against a challenge with virulent tubercle bacili in mice. Since then, ribosomal vaccines have been prepared from many different microorganisms, among which were both extracellular bacteria such as Streptococcus pneumoniae (43), Streptococcus pyogenes (36), Neisseria meningitidis (42) and Pseudomonas aeruginosa (39), as well as intracellular bacteria i.e. Listeria monocytagenes (49), and Salmonella typhimurium (18,45), yeasts as Histoplasma capsulatum $(14)$ and Candida albicans (26), and the protozoan Toxoplasma gondi (4). Some of the ribosomal vaccines offered advantages over the more "conventional" vaccines of the same microorganism. In contrast to the BCG vaccine, the ribosomal vaccine from M. tuberculosis was a non-living vaccine which did not induce tuberculin sensitivity (63). The ribosomal vaccines from $S$. pneumoniae and $S$. pyogenes induced cross-serotype protection (36, 43), while the protection induced by the ribosamal vaccine of 5 . typhimurium lasted longer than the protection by acetone killed salmonella cells (3). Ribosomal vaccines were generally believed to be low toxic, although only few data on the toxicity of the ribosomal preparations have been presented (2). A vaccine containing ribosomal ribonucleic acid (RNA) from $S_{*}$ pneumoniae, Klebsiella pneumoniae, Haemophilus influenzae, 5. pyogenes, supplemented with a membranal fraction of K. prieumoniae, was succesfully used for patients with high respiratory infectious risk (9).

During the first years of research on ribosomal vaccines (1965-1975) several investigators felt that $r$ ibosomal components, i.e. RNA or protein, were responsible for the protective activity of their ribosomal. vaccine $(4,14,19,43,48,61)$. Most of the pioneering work of Youmans and Youmans on the ribosomal vaccine of M. tuberculosis has been published in that period including convincing evidence that RNA was the protective immunogen in their ribosomal preparation (61).

A few reports suggested that ribosomes or ribosomal components might function as carrier, adjuvant or immune modulator for conta- 
minating cel1-surface antigens $(1,13)$.

In most of the recent literature the protective activity of the ribosomal vaccine has been ascribed to cell envelope components in the preparation. No indications were found that ribosomal constituents contributed to the protection induced by these vaccines $(5,12,15,17,25,33,35)$.

The confusion with respect to the question which component( $s$ ) in the ribosomal vaccine were responsible for the protective activity is illustrated by the work on ribosomal vaccines of salmonella. In different studies the protective activity of salmonella ribosomes was ascribed to RNA (46), ribosome associated protein (19), cell surface proteins (33) or lipopolysaccharide (LPS) $(12,25)$.

The apinions about the mechanism of action of ribosomal vaccines were even more divergent. Lin and Berry found that the protective activity of salmonella ribosomes was mediated by serum but not by cells (25), Smith and Bigley associated the protection by salmonella RNA-protein fractions with delayed type hypersensitivity (38), and Venneman and Berry observed that protection by purified RNA could only be passively transferred by cells and not by serum (47). Araujo and Remington (4) suggested that the protection by toxoplasma RNA was mediated by activation of macrophages. After Intensive studies Youmans and Youmans came to the hypothesis that the ribosomal RNA of $M$. tuberculosis was transcribed in the mammalian cell transforming this cell to an immune cell (61).

A more detailed look at the pioneering work of Youmans and Youmans, the different studies on ribosomal vaccines of salmonella, and at those ribosomal vaccines that were found to be RNase sensitive might be helpful to evaluate the confusing literature on the protective components of ribosomal vaccines.

\section{THE RIBOSOMAL VACCINE OF MYCOBACTERIUM TUBERCULOSIS}

Since living tubercle bacilii were known to be more potent jumunogens than killed bacteria Youmans and Youmans (61) postulated that a labile component of these bacteria was required for optimal protection. Fractionation of living mycobacterial cells yielded the highly protective "particulate fraction". The protective activity of this ribosome rich fraction was reduced slightly by treatment with ribonuclease (RNase) (50). Further purification of the ribosomes reduced their protective activity. However, significant protection could be obtained when the purified ribosomes were incorporated in Freund's Incomplete Adjuvant $(F I A)$. The experiments suggested that membrane-like compounds in the particulate fraction functioned as an adjuvant for the ribosomes (51). Intraperitoneal injection of 1 to 20 milligrams of ribosomes, incorporated in FIA, protected mice against a lethal challenge 
with virulent tubercle bacilli which were injected intravenously 4 weeks later. The purification procedure involved breaking of the living cells in a French press, differential centrifugation to obtain a ribosome rich pellet (the particulate fraction), and washing of the ribosomes with sodium dodecyl sulphate (SDS) (52). RNA was further purified by ethanol extraction (56). The final RNA preparation consisted of RNA and protein in a ratio of about $2: 1$. After improvement of the purification method 0.5 microgram of the RNA preparation sufficed to protect mice (56). The immunogenicity of the RNA preparation increased when the mycobacteria were harvested in the logarithmic growth phase instead of in the stationary phase, probably because the RNA was then less degraded (55, 59). The intraperitoneal and subcutaneous routes were equally effective for the induction of immunity. No protection, however, was obtained after intravenous injection (56).

Much attention has been paid to the role of the adjuvant FIA. The mode of preparation of the emulsion affected the reproducibility of the protection by RNA. Biodegradable adjuvants could not replace FIA (54). Youmans and Youmans also tried to replace FIA by polybasic amines, which formed complexes with the RNA. Non of these substances, but DEAE-dextran, enhanced the immunogenicity of RNA. DEAE-dextran alone produced a low degree of nonspecific protection (58). Youmans and Youmans suggested that the function of FIA was primarily to protect the mycobacterial RNA from degradation by the host's RNase. However, no experimental evidence could be found for this hypothesis.

Different results have convinced Youmans and Youmans that RNA was the immunogen in their ribosomal vaccine. The protective activity of the ribosomal preparation was decreased by fifty percent after treatment with RNase, while it was not affected by trypsin or DNase (53). Protein isolated from the ribosomal vaccine did not induce protection. In order to determine whether RNA might be required as an adjuvant for the ribosomal proteins, synthetic polyribonucleotides, were added to the isolated proteins. No protection was obtained. Poly (A.U) could not restore the protective activity of a ribosomal vaccine of which the RNA was partially or totally degraded (57). Furthermore, the immunagenicity of a ribosomal preparation was correlated with the sedimentation value of RNA indicating that intact double stranded RNA was required for protective activity (59). Although the mycobacterial RNA could act as an adjuvant for the induction of delayed type hypersensitivity by purified protein derivate (PPD) ( $B$ ), the ribosomal vaccine itself did not induce tuberculin sensitivity (63). This was an interesting observation since allergic reactions to mycobacterial cell envelope components were supposed to contribute to the protection which is induced by BCG.

The mechanism by which the virulent tubercle bacilli were eliminated in the immunized host was demonstrated in an in vitro 
system. Lymphocytes of mice which were vaccinated with the mycobacterial RNA elaborated a filterable substance which caused inhibition of the multiplication of the mycobateria in normal mouse peritoneal macrophages (34). From these results Youmans and Youmans concluded that the labile but potent protective immunogen of the living tubercle bacillus was RNA (61).

This conclusion raised the difficult question how mycobacterial RNA could induce immunity to tuberculosis. The mycobacterial RNA could function as an adjuvant for various antigens equal to or better than poly (A.U) $(8,64)$, No contaminating antigens were detected in the RNA preparation which could account for the protective activity. Nonspecific immunity to $\mathrm{K}$. pneumoniae but not to L. monocytogenes was induced during 4 days after injection of the ribosomal vaccine (11). Four weeks after vaccination, however, the immunity was specific since no protection against $k$. pneumoniae, L. monocytogenes (11) or M. leprae (37) was observed at that time.

Insight in the mechanism which was involved in the induction of the immune response by RNA was obtained by the use of metabolic inhibitors. Compounds which inhibited protein synthesis in the host, including antibody formation, did not affect the induction of immunity by RNA. Inhibitors of DNA synthesis reduced significantly the immune response. Actinomycin D, which inhibited RNA transcription, reduced the immune response when it was injected 18 hours after vaccination. The whole pattern of chemical compounds which inhibited the immune response induced by mycobacterial RNA closely resembled the inhibition pattern for RNA tumor viruses (60). No correlation was found with the inhibition of the formation of antibodies or the development of delayed type hypersensitivity by the chemicals (62). From these results Youmans and Youmans postulated that the mycobacterial RNA might induce immunity by a mechanism similar to the replication of RNA tumor viruses, i.e. by forming a DNA template in the host's cell, which then transcribes specific information for the replication of mycobacterial. RNA and thereby transforms a normal cell into a specific immune cell (60).

The observations that mycobacterial RNA could inhibit murine tumor growth $(29,30)$ makes this hypothesis even more intriguing.

PROTECTIVE COMPONENTS IN RIBOSOMAL VACCINES OF SALMONELLA TYPHIMURIUM

The history of ribosomal vaccines from 5 . typhimurium is illustrative for the confusing findings about ribosomal vaccines. Ribosomal RNA (46), ribosomal protein (19), cell surface proteins (33), and 0 antigens $(12,25)$ were reported to be the protective component in ribosomal preparations of salmonella. 
In 1969 Venneman and Bigley (45) reported that a ribosome rich preparation, and a RNA extract from the ribosomes protected mice against a lethal challenge. Their purification procedures were basically those of Youmans and Youmans $(52,56)$. One microgram of a subcutaneously injected ribosomal vaccine was sufficient to protect mice against an intraperitoneal challenge with $100 L_{50}$ is days later. Unlike the ribosomal vaccine of $M$. tuberculosis the vaccine of salmonella could be applied without adjuvant and the protective activity was not sensitive to ribonuclease, trypsin or pronase. During further purification of the RNA preparation by columin chromatography the protective activity remained associated with the RNA (48).

The immunogenicity of RNA was called in question when Hoops et al. found that ribosomes which were washed with $1 M \mathrm{NH}_{4} \mathrm{Cl}$ were poorly immunogenic, while the washfluid contained protective antigens $(7,17)$. The protective activity of the different preparations corresponded with their endotoxin activity. Additional evidence that 0 antigens could be involved in the protective activity of ribosomal vaccines was presented by Lin and Berry in 1978 (25). They studied crude ribosomal preparations from a mutant strain of salmonella, which did not synthesize 0 antigens when the bacteria were grown in absence of galactose. Protection and antibodies to LPS were only induced by vaccines prepared from bacteria which were grown in the presence of galactose.

In 1972 Johnson (18) had reported that the protective activity of a ribosomal vaccine of salmonella was sensitive to pronase and trypsin. He prepared the ribosomes essentially according to Youmans and Youmans, but different methods were used to extract and purify RNA and protein. Vaccines were injected subcutaneously without adjuvant and the mice were challenged 15 days later intraperitoneally with $100 L_{50}$ of $\mathrm{S}$. typhimurium. Protection was evident as early as 5 days after vaccination and was specific (19). Purified proteins $(200 \mu \mathrm{g})$ protected mice but RNA failed to induce immunity, whether it was incorporated in FIA or not. Antibodies to LPS were induced by the RNA preparation but not by the protein fraction $(18,19)$.

In later experiments Misfeldt and Johnson (31, 32, 33) used a ribosomal vaccine which was prepared by differential centrifugation without further purification and they immunized mice twice intraperitoneally. Although this ribosomal vaccine induced antibodies to LPS no correlation was found between the titers of antibodies to LPS and the protection induced by the vaccine in various inbred mouse strains with different sensitivities for LPS (31). Protein but not RNA isolated from the ribosomes protected those inbred strains that were protected by the ribosomal vaccine (32). One year later Misfeldt and Johnson identified protective cell surface proteins in ribosomal vaccines from salmonella (33). 
Thus extrinsic proteins appeared to be responsible for the protective activity of the ribosomal vaccine.

In 1975 Eisenstein (12) demonstrated that contaminating 0 antigens contributed to the protective activity of RNA vaccines from salmonella. Mice were immunized intraperitoneally with $44 \mathrm{mg}$ of ribosome-extracted RNA without adjuvant and challenged intraperitoneally 14 days later. RNA vaccines from rough LPS defective mutant strains of salmonella induced less protection against challenge with the smooth parent strain than RNA vaccines from the challenging organism. Also anti-LPS antibodies were detected in sera of RNA-immunized mice. However, a serotype-nonspecific antigen was found in a RNA preparation of 5 . adelaide since this vaccine protected mice also against 5 . typhimurium which did not share 0 antigens with 5 . adelaide. For subsequent studies ribosomes prepared by ammonium sulphate precipitation were used as a vaccine $(3,13)$. In contrast to purified LPS this ribosomal vaccine induced antibodies to LPS in the LPS-insensitive $\mathrm{C}_{3} \mathrm{H} / \mathrm{HeJ}$ mice. Eisenstein suggested that the ribosomal preparation might modulate the immune response to the contaminating LPS in $\mathrm{C}_{3} \mathrm{H} / \mathrm{HeJ}$ mice (13). Immunity induced by ribosomes lasted longer than immunity induced by acetone killed cells or by purified LPS and the differences in protection could not satisfactory be explained by differences in the titers of antibodies to LPS (3).

Eisenstein and Angerman were the only investigators who found indications that immunity induced by ribosomal vaccines of salmonella, could not entirely be ascribed to contaminating cell envelope antigens. Although it is conceivable that the cross-species protection, the protection in $\mathbb{C}_{3} \mathrm{H} / \mathrm{HeJ}$ mice, and the duration of protection had something to do with the presence of the ribosomes in the ribosomal vaccine, these particular properties could also be due to other contaminants in the ribosomal preparation.

The test system of Eisenstein and Angerman differed from those of the other investigators in thet vaccination and challenge were given by the same route, i.e. intraperitoneally. In this test system a local nonspecific immunity might have been induced by the ribosomal vaccines. Misfeldt and Johnson also injected their vaccine intraperitoneally, but they gave a second booster injection, thus stimulating the antibody response to their protein antigens. Little attention was paid to their finding that ribosomal RNA induced significant protection in two inbred strains of mice. These mice were also protected against salmonella by pneumococcal ribosomes or by poly (I.C), indicating that RNA preparations induced nonspecific resistance in these strains of mice (32).

It is noteworthy that early work on ribosomal vaccines of salmonella was performed with purified RNA and protein, while in later work unpurified ribosomal preparations were used. In such complex vaccines cell envelope antigens might easily dominate when 
the test system favoums the expression of antibody madiated immunity.

RIBONUCICASE SENSTITVE RIBOSOMAL VACCINES DF VARIOUS MICHOURGANISMS

During the last four years articles concerning the nature of the protective components in ribosomal vaccines of 5 . pmeumoniae (5), S. pyogenes (16), L. monocytogenes (49), H. influenzae (20, 41), K. pneumoniae (35), Neisseria gonor rhoeae (10) and Bordetella pertussis (15) have been published. Among these more recently described ribosomal vaccines only in case of the RNA preparation of $L$. monocytogenes evidence was presented that RNA was involved in the protective activity of the vaccine, since treatment with RNase destroyed the protective activity.

Sensitivity to RNase has been one of the most convincing arguments that the ribosomes, or ribosomal RNA were involved in the protective activity of a ribosomal vaccine. Many investigations have demonstrated that protective cell surface antigens were easily coextracted with the sticky ribosomes. Since the application of ribosome-containing vaccines is only worthwile when the ribosomes enhance the protective activity of the vaccine, special attention is paid in this review to RNase sensitive ribosomal vaccines.

Except for the ribosomal vaccine of $M$. tuberculosis, which was discussed in a previous section, and the RNA preparation of $\underline{L}$. monocytogenes, ribosoma vaccines of $S$. pneumoniae, $H$. capsulatum, Francisella tularensis, Pasteurelia multacida, and . gondii were reported to be sensitive to RNase.

Thompson and Snyder prepared a crude ribosomal preparation from a nonencapsulated 5 . pneumoniae type 3 . Mice were injected intraperitaneally with 1 miligram (wet weight) of the preparation and challenged intravenously (43) or intraperitoneally (5, 44) with virulent, encapsulated bacteria 3 weeks later. The immunogenicity of the vaccine was slightly enhanced by incorporation in FIA. The protective activity was decreased by treatment with protease and destroyed by treatment with RNase. The ribosomal vaccine induced also protection against several other serotypes of 5 . pneumoniae (43). The protection was serum mediated, and the protective activity of immune serum could be absorbed with rough or smooth type 3 organisms, but not with other serotypes of 5 . pneumoniae. No antibodies to capsular polysaccharide could be detected in the protective sera (44). Heat killed cells could also induce protection against various serotypes of 5 . pneumoniae (5) suggesting that the immunogen in the ribosomal vaccine might be a cell surface component. This hypothesis was supported by the finding that ribosomes which were purified by sucrose gradient centrifugation 
and ribosomes isolated from wal-deficient protoplasts were not protective. A crude cell wall preparation induced also crossserotype protection, but purified, RNase and pronase treated cell walls were not protective.

Au and Eisenstein (5) suggested that a cell envelope component in the ribosomal vaccine had to be complexed with the ribusames in order to be immunagenic.

The ribosomal vaccine of $H$. capsulatum (14) was prepared according to the method of Youmans and Youmans. Mice were injected subcutaneously with 20 to 200 micrograms of ribosomes and challenged intravenously 3 weeks later. Incorporation in FIA enhanced the immunogenicity of the ribosomal preparation. The protective activity was sensitive to both RNase and pronase. Subsequent studies demonstrated that protein isolated from the ribosomes induced significant immunity while phenol extracted RNA was poorLy protective (40). The immunity induced by the ribosomes was species specific since no protection was obtained against Blastomyces dermatitidis, C. albicans, Cryptococcus neoformans and S. enteritidis. The function of RNA in the vaccine was not elucidated.

Phenol extracted RNA prepared from an attenuated strain of F. tularensis protected mice against a virulent strain of this microorganism (1). Mice were vaccinated intraperitoneally or subcutaneously with 5 to 50 micrograms of RNA without adjuvant and challenged 15 days later. The pratective activity of the RNA extract was destroyed by treatment with RNase but it was not affected by pronase. The protection was specific since a RNA extract of Staphylococcus aureus did not induce protection against $F$. Eularensis. The finding that the RNA preparation induced opsonic antibodies suggested that RNA functioned as a carrier or an adjuvant for a cell surface antigen.

Purified ribosomes $(0.25$ to $1 \mathrm{mg})$ isolated from $P$. multocida were injected subcutaneously in mice without adjuvant and the challenge was given subcutaneously 15 days later (6). Ribosomes and phenol killed bacteria protected mice against P. multocida, while LPS from these bacteria was not protective. RNase treatment of the ribosomal fraction reduced the protective activity with 60\%. However, isolated ribosomal RNA or protein did not protect the mice. Baba (6) suggested that either the isolated RNA might have been degraded or contaminating antigens in the ribosomal preparation might have been required for the protection.

Phenol extracted RNA from $T$. gondi was used by Araujo and Remington (4) to protect mice against a challenge with the protozoa. Mice were injected intraperitoneally with 200 micrograms of RNA and challenged intraperitoneally 30 days later. No protection was obtained 15 days after vaccination. Incorporation of the vaccine in FIA reduced the protective dose from 200 to 50 micrograms. The protective activity of the preparation was sensitive to RNase but not to pronase. Mice could also be protected against 
toxoplasma by synthetic polynucleotides and by RNA extracted from normal mouse macrophages. Toxoplasma RNA seemed to activate macrophages since the macrophages of immunized mice resisted a challenge with listeria in vitro.

Effective immunity against $L$. monocytogenes could only be induced by an injection with a sublethal dose of viable microorganisms. However, Willers et al. (49) found that killed or disrupted cells of $L$. monocytogenes became protective when the prepa-. rations were mixed with the adjuvant dimethyldioctadecylammonium bromide (DDA) and were injected intraperitoneally. Fractionation of disrupted listeria showed that the fraction with the highest nucleic acid content $(60 \%)$ induced protection in the smallest dose $(0.3$ microgram). Protection was only obtained when the fraction was mixed with DDA. The protective activity of the nucleic acid rich preparation was abolished by treatment with RNase. Desoxyribonuclease slightly reduced the protective activity while trypsin had no effect.

Although the 6 ribosomal preparations and the ribosomal vaccine of $M$. tuberculosis shared the particular property that they were sensitive to RNase, the vaccines differed with respect to the isolation procedures, the requirement for adjuvant, the routes of immunization and challenge and the optimal interval between the injections. However, there is a point of agreement between the 6 of the 7 vaccines with respect to the organism from which they were prepared. The bacteria M. tuberculosis, L. monocytogenes, F. tularensis and $P$. multocida, the yeast $H$. capsulatum and the protozoa T. gondi each persist for longer periods and eventually grow in the macrophages of the host.

The studies on the RNA vaccine of $T$. gondii demonstrated that different types of RNA increased the resistance of mice, possibly because activation of macrophages had taken place. Similar results werc obtained by Misfeldt and Johnson (32) who showed that not only salmonella RNA but also pneumococcal ribosomes and poly (1.C) could protect two inbred strains of mice against a lethal salmonella challenge.

In this context the study of Medina et al. (28) should be mentioned concerning the induction of nonspecific resistance by RNA $\quad$ n inbred strains of mice. Mice were vaccinated subcutaneously witm 50 micrograms of RNA without adjuvant and challenged intravenously 10 or 20 days later. Ribosomal RNA from salmonella and from listeria, yeast RNA, calf thymus RNA, poly (I.C) and BCG each could protect $[57 \mathrm{BL} / 6]$ mice against a challenge with listeria but not against salmonella. These mice are inherently resistant to listeria and susceptible to salmonella. A/J mice, which are susceptible to listeria and resistant to salmonella, were protected by the RNA preparations against salmonella but not against $\mathbb{1}$ isteria. The multiplication of listeria in livers and spleens of $\mathrm{C57} \mathrm{BL} / 6 \mathrm{~J}$ mice was inhibited in animals which were immunized with salmonella RNA, 
while the salmonella bacteria multiplied with the same rate in immunized and control mice of this strain. These results demonstrated that RNA preparations could induce protection against microorganisms for which the host was inherently resistant. The protection was probably due to activation of the macrophages. It should be noted that Medina et al. (28) challenged both the resistant and the sensitive mice with the same number of viable bacteria. In terms of $L_{50}$ the sensitive mice received a much higher challenge than the resistant inice. When the RNA preparations had induced a moderate degree of resistance in the sensitive mice, thiss resiatance might have been overwhelmed by the high challenge dose.

With respect to the ribosomal vaccines of S. pneumoniae, H. capsulatum, and F. tularensis, evidence was presented that the protective activity was mainly due to cell surface antigens. The RNase sensitivity of these vaccines was supposed to be due to a carrier or an adjuvant function of RNA for the contaminating antigens. Purified ribosomes or RNA were not protective against 5 . pneumoniae and $H$. capsulatum respectively. Suboptimal immunization schedules and high chalienge doses might have prevented that a moderate increase in resistance due to the RNA was observed in these experiments.

These considerations suggest, that the function of RNA in RNase sensitive ribosamal vaccines is to induce nonspecific resistance which may enhance the expression of immunity due to antibodies against contaminating cell surface antigens. The fact that RNase sensitivity was almost exclusively observed for ribosomal vaccines from intracellular parasites might be an important indication for the mechanism by which RNA induced nonspecific resistance.

\section{RIBOSOMAL VACCINES FROM PSEUDOMONAS AERUGINOSA}

Ribosomal vaccines from $P$. aeruginosa have been studied by several investigators. Smith et al. (39) and Mates and Zand (27) prepared SDS washed ribosomes according to the method of Youmans and Youmans; Lieberman (22) isolated ribosomal preparations from several serotypes of $p$. aeruqinosa by ammonium sulphate fractionation. The different ribosomal vaccines protected mice only against the homologous serotype. No further experimental evidence was presented which explained the nature of the protective component(s) in these ribosomal preparation. Since the most recent, and the most detailed studies have been published by Lieberman, this work will be discussed here.

Optimal protection by the ribosomal preparations of Lieberman was achieved when mice were injected twice, subcutaneously, with an 8-day interval, and were challenged intraperitoneally 10 days arter the last injection (22). However, mice could be protected 
during 3 months after this immunization schedule. No adjuvant has been applied. Ribosomal preparations from 5 out of 8 serotypes. protected mice against a homologous challenge when 1.6 to 40 micrograms of RNA were injected. No carrelation was found between the protective activity and the RNA to protein ratio of the prepa-rations. Molecular sieve chromatography on Sepharose $4 B$ of 2 protective and 1 nonprotective vaccine yielded different patterns. The protective vaccines were separated in two fractions, i.e. peak A containing material with a molecular weight $\geqslant 2 \times 10^{7}$ daltons, and peak B containing ribosomes. The nonprotective ribosomal preparation yielded only a peak at the $B$ position. Peak A contained RNA and protein in a ratio of ca. 1:3, the ratio of RNA to protein in peak $B$ was $2: 1$. To estimate the contamination of peak $A$ and $B$ with LPS, bacteia were grown in a medium with radioactive labeled glucose, which incorporates in LPS (21, 22). Fighteen percent of the cell bound radioactivity was recovered in the ribosomal preparation. One third of this radioactivity was found in a neutral sugar fraction of peak $A$, while virtually no radioactivity was found in a similar prepared neutral fraction of peak B. Based on the RNA content 5 to 10 fold higher concentrations of peak $B$ than of peak $A$ were required to protect mice. Neither peak $A$ nor peak $B$ were sensitive to $r$ ibonuclease or trypsin.

Antisera raised in rabbit against the unfractionated ribosomal preparation and against peak $A$ and $B$ protected mice against the homologous $P$. aeruginosa strain (23). Agar gel diffusion experiments suggested that unfractionated vaccine, peak $A$ and $B$ contained a common antigenic component, while an additional antigen in the unfractionated vaccine was not present in peak $B$.

Passive haemagglutination was only observed when antiserum to peak $A$ was tested against erythrocytes coated with peak $A$ by a method which is usually applied to coat erythrocytes with LPS. Purified LPS inhibited this haemagglutination reaction, confirming that antiserum to peak A contained antibodies to LPS. No experiment was reported in which antiserum to peak $B$ was tested with peak $A$ coated erythrocytes. A complement fixation test also suggested that a common antigen was present in peaks $A$ and $B$, while additional antigenic material was only present in peak $A$.

Two polyvalent antisera were raised in rabbit by sequential administration of unfractionated ribosomal vaccines derived from 4 or 6 serotypes ( 24 ). Mice could be passively protected by these antisera against 3 out of 4 , or 5 out of 6 of the homologous $P$. aeruginosa strains. The polyvalent antisera did not protect against heterologous serotypes with one exception.

The results presented by Lieberman strongly suggested that the unfiractionated ribosomal vaccine and peak $A$ were contaminated with LPS. The protective activity of polyvalent antisera to unfractionated ribosomal vaccines is likely to be due to antibodies to l.pS 
since the protection was restricted to the homologous serotypes. No LPS was found in peak B when radioactive labeled qlucose was used to detect this contaminant. Since active immunization with peak $B$, and passive immunization with antiserum to peak B protected mice against a homologous challenge, the nature of the antigen in peak $B$ is of particular interest. In a presentation at the annual meeting of the American Society for Microbiology in 1980 Lieberman suggested that outer membrane proteins, which could induce protective antibodies, were present in the unfractionated ribosomal vaccine and in peak $B$. Whether the outer membrane proteins are free of LPS and responsible for the protective activity of peak $B$ ribosomes has to be demonstrated.

\section{LITERATURE}

1. Andron, L.A., and H.T. Eigelsbach. 1975. Biochemical and immunological properties of ribonucleic acid rich extracts from Francisella tularensis. Infect. Immun. 12: 137-142.

2. Angerman, C.R., and T.K. Eisenstein. 1978. Comparative efficacy and toxicity of a ribosomal vaccine, acetone killed cells, lipopolysaccharide, and a live cell vaccine prepared from Salmonella typhimurium. Infect. Immun. 19: 575-582.

3. Angerman, C.R., and T.K. Eisenstein. 1980. Correlation of the duration and the magnitude of protection against salmonella infection afforded by various vaccines with antibody titers. Infect. Immun. 27: 435-443.

4. Araujo, F.G., and J.5. Remington. 1974. Protection against Toxaplasma gondii in mice immunized with toxoplasma cell fractions, RNA and synthetic polyribonucleotides. Immunology 27: 711-721.

5. Au, C.C., and T.K. Eisenstein. 1981. Nature of the crossprotective antigen in subcellular vaccines of Streptococcus pneumoniae. Infect. Immun. 31: 160-168.

6. Baba, T. 1977. Immunogenic activity of a ribosomal fraction obtained from Pasteurella multocida. Infect. Immun. 15: 1-6.

7. Berry, L.J., G.N. Douglas, P. Hoops, and N.E. Prather. 1975. Immunization against salmonellosis, p. 388-398. In E. Neter and $F$. Milgrom (eds.), The immune system and infectious diseases, Fourth International Convocation on Immunology, Buffalo, N.Y., 19774. S. Karger Verlag AG, Basel.

8. Casavant, C.H., and G.P. Youmans. 1975. The adjuvant activity of mycobacterial RNA preparations and synthetic polynucleotides for induction of delayed hypersensitivity to purified protein derivative in guinea pigs. J. Immunol. 114: 1014-1022. 
9. Characon, R., P.J. Lavillauroy, and J.P. Fumex. 1980. Multicentric study of the effectiveness of ribosomal vaccine (D53) in the prevention of episodes of bacterial infection encountered in ENI pathology. Drug. Res. 30: 214-220.

10. Cooper, M.D., R.P. Tewari, and D.V. Bowser. 1980. Immunogenicity of ribosomal preparations from Neisseria gonorrhoeae. Infect. Immun. 28: 92-100.

11. Coppel, S., and G.P. Youmans. 1969. Specificity of acquired resistance produced by immunization with mycobacterial cells and mycobacterial fractions. J. Bacteriol. 97: 114-120.

12. Eisenstein, T.K. 1975. Evidence for 0 antigens as the antigenic determinants in ribosomal vaccines prepared from salmonella. Infect. Immun, 12: 364-377.

13. Eisenstein, T.K., and C.R. Angerman. 1978. Immunity to experimental salmonella infection: studies on the protective capacity and immunogenicity of lipopolysaccharide, acetonekilled cells, and ribosome-rich extracts of Salmonella typhimurium in $\mathrm{C}_{3} \mathrm{H} / \mathrm{HeJ}$ and $\mathrm{CD}-1$ mice. J. Immunol. 3: 10101014.

14. Feit, C., and R.P. Tewari. 1974. Immunogenicity of ribosomal preparations from yeast cells of Histoplasma capsulatum. Infect. Immun. 10: 1091-1097.

15. Field, L.H., C.D. Parker, C.R. Manclark, and L.J. Berry. 1979. Evaluation of a ribosomal vaccine against pertussis. Infect. Immun. 24: 346-351.

16. Green, B.A., and W. Johnson. 1980. Immunogenicity of ribosomes from enzymatically lysed Streptococcus pyogenes. Infect. Immun. 27: 424-430.

17. Hoops, P., N.E. Prather, L.J. Berry, and J.M. Rave1. 1976. Evidence for an extrinsic immunogen in effective ribosomal vaccines from Salmonella typhimurium. Infect. Immun. 13: 11841192.

18. Johnson, W. 1972. Ribosomal vaccines. I. Immunogenicity of ribosomal fractions isolated from Salmonella typhimurium and Yersinia pestis. Infect. Immun. 5: 947-952.

19. Johnson, W. 1973. Ribosomal vaccines. II. Specificity of the immune response to ribosomal ribonucleic acid and protein isolated from Salmonella typhimurium. Infect. Immun. B: 395400.

20. Katz, M., M. Lynn, and M. Solotorovsky. 1981. Serological and biological activities of anti-Haemophilus influenzae ribosomal serum. Infect. Immun. 31: 1125-1131.

2]. Lieberman, M.M. 1977. Direct evidence for the presence of lipopolysaccharide components in a pseudomonas ribosonal vaccine. Infect. Immun. 17: 471-473.

22. Lieberman, M.M. 1978. Pseudomonas ribosomal vaccines: preparation, properties and immunogenicity. Infect. Immun. 21: 7686. 
23. Lieberman, M.M., D.C. Mckissock, and G.L. Wright. 1979. Passive immunization against pseudomonas with a ribosomal vaccine-induced immune serum and immunoglobulin fractions. Infect. Immun. 23: 509-521.

24. Lieberman, M.M., G.L. Wright, K.M. Wolcott, and D.C. Mckissock-Desato. 1980. Polyvalent antisera to pseudomonas ribosomal vaccines: protection of mice against clinically isolated strains. Infect. Immun. 29: 489-493.

25. Lin, J.H., and L.J. Berry. 1978. The use of strain LT2-ML in identifying the protective antigens in a Salmonella typhimuc zum derived ribosomal vaccine. J. Reticuloendothel. 5oc.. 23: $135-143$.

26. Lewy, R., E. Segal, and E. Eylan. 1981. Protective immunity against murine candidiasis elicted by Candida albicans ribosomal fractions. Infect. Immun. 31: $874-\overline{878 .}$

27. Mates, A., and P. Zand. 1974. Specificity of the protective response induced by the slime layer of Pseudomonas aeruginosa. J. Hyg. (London) 73: 75-84.

28. Medina, S., S.J. Vas, and H.G. Robson. 1975. Effect of nonspecific stimulation on the defense mechanisms of inbred mice. J. Immuno 1. 114: 1720-1725.

29. Millman, I., H.C. Maguire, G.P. Yaumans, and A.S. Youmans. 1974. Effect of the H37Ra strain of M. tuberculosis and of a mycobacterial RNA fraction on tumor growth (38434). Proc. Soc. Exp. Biol. Med. 147: 765-768.

30. Millman, I., A.W. Scott, T. Halbherr, A.S. Youmans, and G.P. Youmans. 1976. Mycobacterial ribonucleic acid: comparison with mycobacterial cell wall fractions for regression of muine tumor growth. Infect. Immun. 14: 929-933.

31. Misfeldt, M.L., and W. Johnson. 1977. Role of endotoxin contamination in ribosomal vaccines prepared from Salmonella typhimurium. Infect. Immun. 17: 98-104.

2. Misfeldt, M.L., and W. Johnson. 1978. Protective ability of salmonella ribosomal protein and RNA in inbred mice. Infect. Immun. 21: 286-291.

33. Misfeldt, M.L., and W. Johnson. 1979. Identification of protective cell surface proteins in ribosomal fractions from Salmone lla typhimurium. Infect. Immun. 24: 808-816.

34. Patterson, R.J., and G.P. Youmans. 1970. Demonstration in tissue culture of lymphocyte-mediated inmunity to tuberculosis. Infect. Immun. 1: 600-603.

35. Riattol, M.M., J.M. Fournier, and H. Jouin. 1981. Direct evidence for the involvement of capsular polysaccharide in the inmunoprotective activity of Klebsiella pneumoniae ribosomal preparations. Infect. Immun. 31: 71-77.

36. Schalla, W.O., and W. Johnson. 1975. Immunogenicity of ribosomal vaccines isolated from group A type 14 Streptococcus pyogenes. Infect. Immun. 11: 1195-1202. 
37. Shepard, C.C., A.S. Youmans, and G.P. Youmans. 1977. Lack of protection afforded by ribonucleic acid preparations from Mycobacterium tuberculosis against Mycobacterium leprae infections in mice. Infect. Immun. 15: 735-736.

38. Smith, R.A., and N.J. Bigley. 1972. Detection of delayed type hypersensitivity in mice injected with ribonucleic acidprotein fractions of Salmonella typhimurium. Infect. Immun. 6: $384-389$.

39. Smith R.L., J.A. Wysocki, J.N. Bruun, S.J. de Coursy, W.S. Blakemore, and 5. Mudd. 1974. Efficacy of ribosomal preparations from Pseudomonas aeruginosa to protect against intravenous pseudomonas challenge in mice. J. Reticuloendothel. Soc. 15: 22-30.

40. Tewari, R.P. 1975. Immunization against histoplasmosis, p. 441-452. In E. Neter and F. Milgrom (eds.), The immune system and infectious diseases. Fourth International Convocation on Immunology, Buffalo, N.Y., 1974. S. Karger Verlag AG, Basel.

41. Tewari, R.P., M. Lynn, A.J. Birnbaum, and M. Solotorovski. 1978. Characterization of the immunoprotective antigen of ribosomal preparations from Haemophilus influenzae. Infect. Immun. 19: 58-65.

42. Thomas, D.W., and E. Weiss. 1972. Response of mice to injection of ribosomal fraction from group B Neisseria meningitidis. Infect. Immun. 6: 355-363.

43. Thompson, H.C.W., and J.S. Snyder. 1971. Protection against pneumococcal infection by a ribosomal preparation. Infect. Immun. 3: 16-23.

44. Thompson, H.C.W., and T.K. Eisenstein. 1976. Biological properties of an immunogenic pneumococcal subcellular preparation. Infect. Immun. 13: 750-757.

45. Venneman, M.R., and N.J. Bigley. 1969. Isolation and partial characterization of an immunogenic moiety obtained from Salmonella typhimurium. J. Bacteriol. 100: 140-148.

46. Venneman, M.R., N.J. Bigley, and L.J. Berry. 1970. Immunogenicity of ribonucleic acid preparations obtained from Salmonella typhimurium. Infect. Immun. 1: 574-582.

47. Venneman, M.R., and L.J. Berry. 1971. Cell-mediated resistance induced with immunogenic preparations of Salmonella typhimurium. Infect. Immun. 4: 381-387.

48. Venneman, M.R. 1972. Purification of immunogenically active ribonucleic acid preparations of Salmonella typhimurium: molecular sieve- and anion-exchange chromatography. Infect. Immun. 5: 269-282.

49. Willers, J.H.N., N. Bloksma, C. van der Meer, H. Snippe, H. van Dijk, M.J. de Reuver, and F.M.A. Hofhuis. 1979. Regulation of the immune response by macrophages. Antonie van Leeuwenhoek 45: 41-48. 
50. Youmans, A.5., and G.P. Youmans. 1964. Nature of the labile immunogenic substance in the particulate fraction isolated from Mycobacterium tuberculosis. J. Bacteriol. 98: 1030-1037.

51. Youmans, A.S., and G.P. Youmans. 1965. Immunogenie activity of a ribosonal fraction obtained from Mycobacterium tuberculosis. J. Bacteriol. 89: 1291-1298.

52. Youmans, A.S., and C.P. Youmans. 1966. Preparation of highly immunogenic ribosomal fractions of Mycobacterium tuberculosis by use of sodium dodecyl sulphate. J. Bacteriol. 91: 21392145 .

53. Youmans, A.5., and G.P. Youmans. 1966. Effect of trypsin and ribonuclease on the immunogenic activity of ribosomes and ribonucleic acid isolated from Mycobacterium tuberculosis. I. Bacteriol. 91: 2146-2154.

54. Youmans, A.S., and G.P. Youmans. 1967. Preparation and effect of different adjuvants on the immunogenic activity of mycobacterial ribosomal fraction. 1967. J. Bacteriol. 94: 836-943.

55. Youmans, A.S., and G.P. Youmans. 1968. Ribonucleic acid, deoxyribonucleic acid and protein content of cells of different ages of Mycobacterium tuberculosis and the relationship to immunogenicity. J. Bacteriol. 95: 272-279.

56. Youmans, A.S., and C.P. Youmans. 1.969. Factors affecting the immunogenic activity of mycobacterial ribosomal and ribonucleic acid preparations. J. Bacteriol. 99: 42-50.

57. Youmans, A.S., and G.P. Youmans. 197]. Failure of synthetic polynucleotides to affect the immunogenicity of mycobacterial ribonucleic acid and ribosomal preparations. Infect. Immun. 3: $149-153$.

58. Youmans, A.S., and G.P. Youmans. 1972. Effect of polybasic amines on the immunogenicity of mycobacterial ribonucleic acid. Infect. Immun. 6: 798-804.

59. Youmans, A.S., and G.P. Youmans. 1973. The relationship between sedimentation value and immunogenic activity of mycubacterial ribonucleic acid. J. Immunol. 110: 581-586.

60. Youmans, A.S., and G.P. Youmans. 1974. The effect of metabolic inhibitors and hydroxylamine on the immune response in mice to mycobacterial ribonucleic acid vaccines. J. Immunol. 112: 271284.

61. Youmans, A.5., and G.P. Youmans. 1975. Mycobacterial extracts and immunity to tuberculosis, p. 399-4In. In E. Neter and F. Milgrom (eds.), The immune system and infectious diseases. rourth International Convocation on Immunology, Buffalo, N.Y,, 1974. 5. Karger Verlag AG, Basel.

62. Youmans, A.S., and G.P. Youmans. 1978. Effect of metabolic inhibitors on the formation of antibody to sheep erythrocytes, on development of delayed hypersensitivity, and on the immune response to infection with Mycobacterium tuberculasis in mice. Infect. Immun. 19: 212-216. 
63. Youmans, G.P., and A.S. Youmans. 1969. Allergenicity of myeubacterial ribosomal and ribonucleic acid preparationa in mite and guinea pigs. J. Bacteriol. 97: 134-139.

64. Youmans, G.P., and A.S. Youmans. 1972. The effect of mycobacterial RNA on the primary antibody response of mice to bovine globulin. J. Immunol. 109: 217-221. 


\title{
Chapter 3
}

\section{Pseudomonas aeruginosa: virulence and vaccines.}

\author{
VIRULENCE FACTORS
}

Virulence factors of Pseudomonas aeruginosa gained renewed interest since the importance of an exotoxin, named exotoxin $A$, was rediscovered a few years ago. This toxic protein from pseudomonas had the same enzymatic specificity as fragment $A$ from the diphteria toxin: both enzymes had adenosine 5'-diphosphate (ADP)ribosyl transferase activity and inhibited protein synthesis in mammalian cells by inactivation of elongation factor $2(26,27)$. The dose of exotoxin A that was lethal for 50 percent of the injected mice ( $\left.L D_{50}\right)$ was less than $100 \mathrm{ng}(8)$. The toxin was produced in vivo by $P$. aeruginosa multiplying at the burned site of an infected mouse, and the level of active elongation factor 2 was reduced significantly in the livers of infected mice (60). Exotoxin A was toxic for human macrophages impairing phagocytasis in vitro (56). Treatment of burned and pseudomonas infected mice with antiserum to exotoxin $A$ enhanced survival (43) or extended the survival time $(43,65)$, depending on the production of other virulence factors (proteases) by the infecting pseudomonas strain. Walker et al. (68) found that immunization with toxoid from exotoxin A (toxaid A), prepared by glutaraldehyde treatment of toxin $A$, was ineffective in experimental rat burn wound sepsis due to pseudomonas. In contrast, immunization with live pseudomonas provided good strain specific protection in the same model. The poor results obtained after active immunization with toxoid $A$ might be due to the preparation procedure. Immunization with toxoid $A$ prepared by formalin treatment of toxin $A$ and combination of the toxoid $A$ with an adjuvant increased the survival of burned, pseudomonas infected mice (45).

Several clinical studies also indicated that exotoxin $A$ is an important virulence factor. Exotoxin $A$ was produced by approximately $89 \%$ of clinical isolates of $P$. aeruginosa $(6,55,61)$. Higher titers of antibodies to exotoxin $A$ were found in sera of patients who were infected with $P$. aeruginosa than in sera of non-

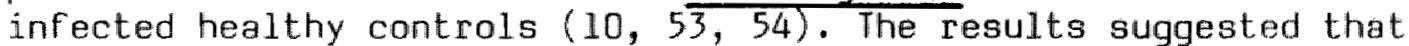
non-fatal pseudomonas infections were associated with higher anti-toxin A titers than fatal pseudomonas infections (10, 53, 57). A study on a small number of patients with $P$. aeruginosa bacteremia in whose sera no anti-toxin $A$ antibodies were found indicated that infections with toxin producing strains were asso- 
ciated with a higher mortality than infections with toxin-negative strains (10). However, several disease producing pseudomonas strains which were isolated did not produce exotoxin A. Mareover, some patients who survived bacteremic pseudomonas infections had no protective serum levels of anti-exotoxin A antibodies (10).

In patients, fatal pseudomonas infections are almost exclusiveIy due to septicemia which is in marked contrast with toxin mediated disease such as diphteria or cholera. Studies in patients with pseudomonas septicemia indicated that anti-lipopolysaccharide (LPS) and anti-toxin A antibodies protected independently and additively (57). Thus, exotoxin A probably has an important but not an exclusive role in pathogenesis of pseudomonas infections $(10,58,71)$.

Two protein-splitting enzymes produced by $P$. aeruginosa named protease and elastase also have been considered as virulence factors. Mast of the clinical isolates of pseudomonas which produced exotoxin A also produced protease and elastase (61). The minimal lethal dose (MLD) of these enzymes for mice depended on the route of injection. The MLD for protease varied from 100 to $300 \mu \mathrm{g}$; the MLD for elastase was 62.5 to $375 \mu \mathrm{g}$ (25). Purified protease or elastase could produce hemorrhage or ulcers when applied to the rabbit skin (25). Microscopic characterization of rabbit lung damage produced by the proteases revealed intraalveolar hemorrhage, necrosis of alveolar cells and infiltration by mononuclear cells, which also occurred during human pseudomanas pneumonia (15). Injection of proteolytic enzymes increased the mortality in a burned mice model in which mice were infected with a Pseudomonas aeruginosa strain producing exotoxin $A$ but no protealytic enzymes and resulted in reduced elongation factor 2 levels in the livers of the infected animals (23). The $L D_{50}$ of a protease-producing $P$. aeruginosa strain in a burned mice model was at least one log less than the $L D_{50}$ of two protease-deficient mutants of this strain. Anti-protease serum increased the percentage of survival of burned mice infected with protease-producing $P$. aeruginosa (44). No contribution of proteases to the virulence of $P$. aeruginosa was found when the protease-producing $P$. aeruginosa strain and 2 protease-deficient mutants were injected intraperitoneally in cyclophosphamide-treated mice (69).

Several mechanisms were proposed by which the proteases might enhance the virulence of $P$. aeruginosa. Proteases were found to enhance the growth of a nonprotease producing strain in an extract of burned skin probably by modifying the available nutrients (9). Elastase inactivated complement components and reduced the phagocytic indices of polymorphonuclear leukocytes for pseudamonas opsonized with complement factor 3 (63). Elastase, and to a lesser extent protease, inactivated human plasma $\alpha_{1}$-proteinase inhibitor in vitro. It was suggested that loss of this inhibitor might permit endogenous serine proteases to cause tissue destruction 
(39). The capacity of culture filtrates of pseudomonas to modify the activity of exotoxin A could not be ascribed to protease or elastase (29). Although it is unlikely that protease and elastase are responsible for the lethality of pseudomonas, these enzymes probably contribute to the virulence by enhancing multiplication and invasion of the bacteria and thereby overcoming the host's initial defence mechanisms (25).

Several other extracellular products of $P$. aeruginosa were described which might contribute to its virulence. Exoenzyme 5 also had ADP-ribosyl transferase activity but it differed from exatoxin $A$ in that the substrate was not elongation factor 2 but one or two other proteins in eucaryotic cells (28). The two enzymes could be distinguished serologically. Exoenzyme 5 was showr to be produced in vivo in a burned mice model. The contribution of exoenzyme $S$ to the virulence of pseudomonas was suggested by the $\mathrm{LD}_{50}$ of an exoenzyme 5 , protease and elastase producing pseudomonas strain, which was 1 logarithm less in a burned mice model than the $L_{50}$ of an exotoxin $A$ and protease producing strain (7). The isolation of an exoenzyme S-producing, exotoxin A-negative strain from a fatal pseudomonas bacteremia has been reported (10).

Under certain conditions many strains of $P$. aeruginosa were shown to produce hemolysins, i.e. phospholipase $\mathrm{C}$ and glycolipid. The latter substance has a detergent-like activity. Hemolysins may play a role in the formation of local lesions by $P$. aeruginosa (35).

A polymorphonuclear leukocyte (PMNL) inhibitor was isolated from the culture fluid of a pseudomonas strain which was resistant to phagocytic and killing activities of rabbit PMNL's $(40,41)$. It was suggested that the PMNL-resistance of 9 out of 15 clinical isolates might be due to the production of this PMNL inhibitor (40). It cannot yet be excluded that this inhibitor is identical with one of the other extracellular products of $P$. aeruginosa.

$P$. aeruginosa produces slime which covers the outer surface of the microorganisms. From this slime, a glycolipoprotein (GLP) has been isolated which may also contribute to the virulence of $P$. aeruginosa. The $L_{50}$ for mice of intraperitoneally injected $G \overline{L P}$ was approximately $600 \mu \mathrm{g}(64)$. GLP was demonstrated to be produced in vivo, and it appeared to enter the peripheral circulation rapidly (11). GLP induced leukopenia in vivo and inhibited phagocytosis in vitro (64). Leukopenia might be due to association of the GLP with leukocytes, which were then sequestered in the liver (36). Active or passive immunization with GLP protected mice against the leukopenic and lethal effects of GLP (36), and antiGLP serum enhanced phagocytosis of $P$. aeruginosa by mouse peritoneal macrophages in vitro (4). The protection by anti-GLP serum against challenge with $P$. aeruginosa was immunotype-specific, but some cross-protection was observed. GLP was shown to be distinct from LPS (64). The $L D_{50}$ 's of different viable P. aeruginosa 


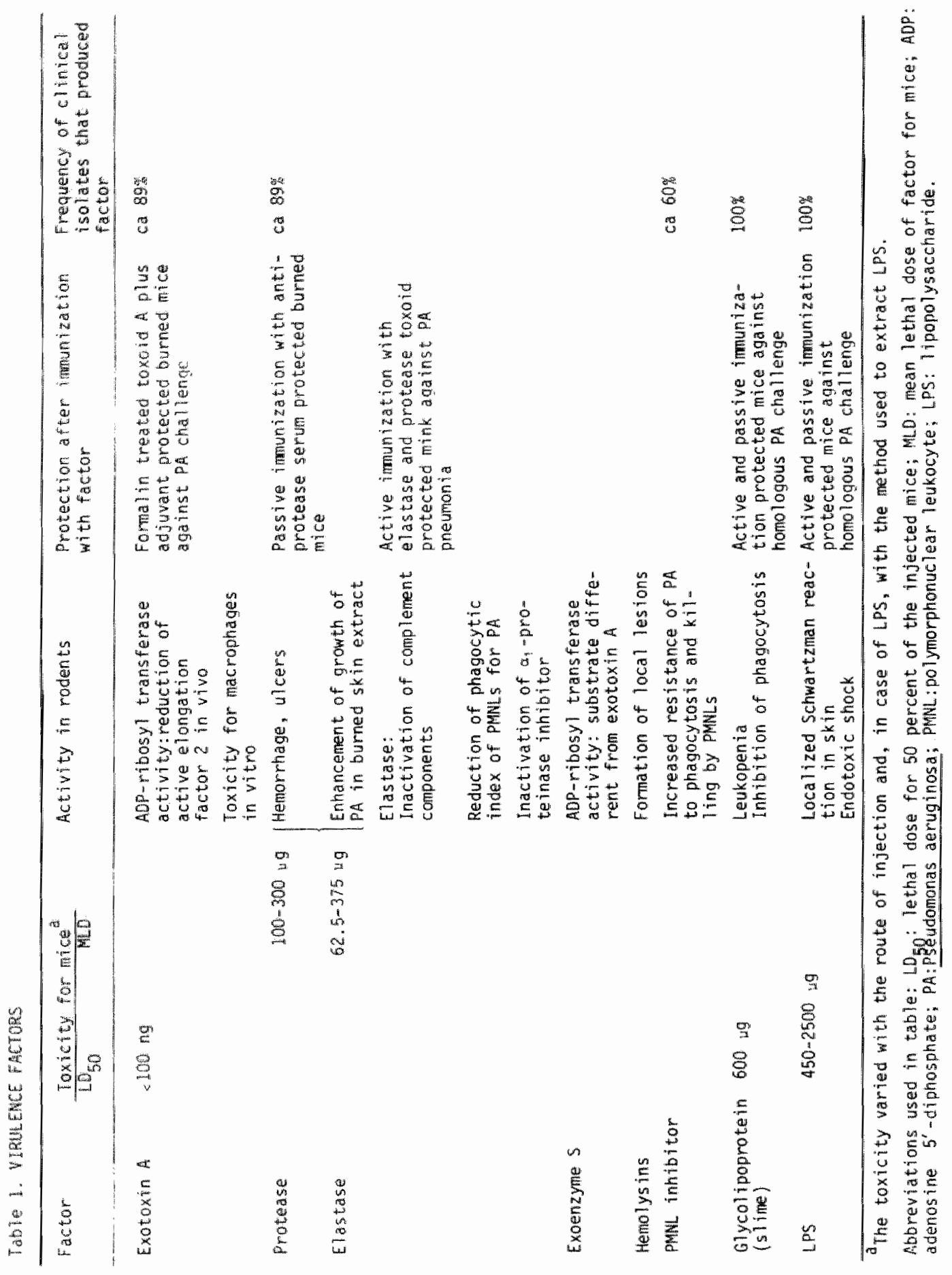


strains did not correlate with the $L_{50}$ 's of the purified GLP's derived from these $P$. aeruginosa strains. The authers suggested that this discrepancy might be due to different rates of production of slime in vivo (12).

The presence of lipopolysaccharide (LPS) in the cell envelope is characteristic for Gram-negative bacteria, including $P$. aeruginosa. LPS from $P$. aeruginosa is similar to the LPS of other bacteria in that it consists of a lipid A part which is linked to a group of polysaccharides. The serotyping scheme of Habs (17) for $P$. aeruginosa is based on 0 antigens which reside in the carbohydrate moiety of LPS. Pathogenicity of several Gram-regative bacteria is mainly due to the toxicity of their LPS, which is refered to as endotoxin. However, the toxicity of LPS from P. aeruginosa for mice is very low. The $L D_{50}$ of phenol extracted LPS was estimated to be $840 \mu \mathrm{g}$ when injected intraperitoneally, and $450 \mathrm{\mu g}$ when LPS was injected intravenously (13). Other extraction procedures yielded less toxic LPS preparations, and several authors mentioned higher $\mathbb{L D}_{50}$ 's for LPS, i.e. 1,2 - 1,8 mg (64) or $2.5 \mathrm{mg}$ (16). The low toxicity of LPS in comparison with extraceliular products of $P$. aeruginosa indicates that LPS does not contribute significantly to the virulence of $P$. aeruginosa. The significant protection obtained after passive or active immunization with LPS is ascribed to opsonizing antibodies enhancing phagocytosis of the invading bacteria.

The toxicity and the mode of action of the different virulence factors of pseudomonas, their protective activity after inmunization, and the frequency of clinical isolates of $P$. aeruginosa that produced the virulence factors is summarized in Table I. These results suggest that the pathogenicity and the virulence of $P$. aeruginosa is mainly due to its extracellular products and the slime covering the bacteria. Extracellular proteases and hemolysins cause tissue destruction and enhance growth of the bacteria. The slime and other extracellular products inhibit phagocytosis of the invading bacteria, and these conditions facilitate the most toxic products of $P$. aeruginosa, exotoxin $A$ and probably exotoxin $S$, to exert their lethal activities in the host.

\section{VACCINES}

$P$. aeruginosa infections almost exclusively occur in the compromised host, in particular in burn patients (5), patients with cancer (67), and cystic fibrosis patients (59). Resistance of the host is mediated by the phagocytic system, and enhanced by opsonizing antibodies. Granulocytopenic patients are at particular risk for pseudomonas infections (70). The main goal of most vaccines of $P$. aeruginosa has been to induce opsonizing antibodies. When recently the role of extracellular products in the pathogenicity of $P$. aeruginosa became apparent, attempts have been made to 
untrol experinental pseudomonas infections by active or passive inhunization against the respective virulence factors.

Normal mice were readily protected by as little as 1 ng of purified LPS against a lethal challenge with the homologous $P$. aeruqinosa strain (52). LPS-inmunized dogs which were made granulocytopenio due to cyclophosphamide treatment showed increased survival in comparison with nonimmunized controls after homologous chaldenge (19). Passive imnunization of the dogs with type specific antiserum increased the mean survival time but could not prevent death (20). Long term survival accurred when pasive immunization was combined with granulocyte transfusions (34).

Guinea pigs could be protected against lethal pseudomonas preunoria by intramuscular immunization with LPS from the challonging strain (49). Opsonic antibodies in the serum of immunized animals probably diffused into the bronchial fluids, since pseudomonas opsonins were locally increased within a few hours after ostablishment of the experimental preumonia (50).

L.PS vaccines were also developed for application in human. For this purpose vaccines had to contain LPS from each of the prevalent serotypes of P. aeruginosa. Fisher et al. (14) developed a new antigenic scheme based on 7 immunotypes. A combination of these 7 immurnotypes could induce protection in mice against $94 \%$ of $342 \mathrm{P}$. agruginosa strains. Hannessian et al. (18) isolated stable LPS from the cell wall of these seven immunotypes, which was usod to prepare a heptavalent pseudomonas vaccine named Pseudogen. Pseudogen has been used to immunize burn patients (3), leukemic patients and patients with cystic fibrosis $(46,47)$. The results suggested that immunization of burn patients, combined with administration of hyperimmune $y$-globulin could prevent them from fatal pseudomonas septicemia. Although immunized leukemic patients tended to have a decreased incidence of death associated with pseudomonas the small number of patients did not permit conclusions. Neither parenteral nor rasal aerosol vaccination of cystic fübrosis patients did result in an improvement (48). Adverse ractions to the vaccime were frequent and often limited the dose givon, especinlly in leukemic patients. The mixing of adrenal waticosteroids with the LPS vaccine dacensed the side reactions, and decreased the antibody response only slight 1 y (47). A vaccine containing cell wall antigens from 16 serotypes of $P$. aeruginosa, probably including LPS, was prepared by Miler el al. (38) and was named PEV-01. This vaccine protected mice within 3 days after a singlo injection. In human volunteers antibodies to vaccine antigens increased, and the immune serum passively protaced mice against a $P$. aeruginose challenge. Some volunteers showed an increase in temperature and local redness, tenderness and induration (30). Active (31) or passive (32) immunization of burn patients in India reduced the incidence of $P$. aeruqinosa bacteremia and the mortality. No observations were reported concerning 
adverse effects during immunization.

A different type of vaccine contained a common protective antigen designated as original endotoxin protein (OEP) of $P$. aeruginosa. OEP is a protein which is associated with LPS. Active or passive immunization of mice with OEP protected against challenges with the 7 immunotypes of Fisher and against the 14 different standard strains of Homma's serotypes. Thus OEP appeared to be a common antigen in all the $P$. aeruginosa serotypes ( 1 ). The protective activity of OEP was reduced after protease treatment, which supported the concept that this common antigen was a protein (2). OEP could also protect burned mice from death due to pseudomonas infection. However, better results were obtained when a detoxified extracellular product of $P$. aeruginosa, elastase toxoid, was used as a vaccine (33). Also mink were better protected against experimental pseudomonas pneumonia infection by elastase toxoid or protease toxoid than by DEP (24). However, burned mice were not protected by a multicomponent vaccine containing DEP, elastase toxoid, protease toxoid and exotoxin $A$ toxoid against two strains of $P$. aeruginosa which did not contain OEP antigen (42). Thus, although the protective effect of the multicomponent vaccine was mainly due to the toxoids of extracellular products, a somatic component like OEP might be essential to protect against some $P$. aeruginosa strains.

A polysaccharide antigen, PS, isolated from the slime of $P$. aeruginosa protected mice against a homologous challenge. PS was immunologically indistinguishable from the polysaccharide part of LPS. PS was less toxic than LPS, but PS also had less protective activity on dry weight basis $(51,52)$.

Recently a common antigen (CA), probably a protein, has been isolated from $P$. aeruginosa which also cross reacted with antigens from many other bacterial species. CA differed biochemically from OCP, and from the Enterobacterial Common Antigen (37). Antibodies to $C A$ were found in $71_{0}^{*}$ of 101 patients suffering from $P$ aeruginosa infection. The protective activity of CA after active or passive immunization has not been reported $(22,66)$. The different types of vaccines and their protective properties are summarized in Table II.

The clinical trial with the vaccine $P E V-O 1$ indicates, that vaccination of burn patients with somatic antigens of pseudomonas is justified in situations where death of such patients from pseudomonas septicenia is common due to inadequate antibacterial therapy and poor condition by malnutrition of patients on admission (31). Since few data are available on the toxicity of PEV-01 it is uncertain whether the adverse reactions observed after injection of Pseudogen in cancer patients will be less severe for PEV-01. A combined vaccine containing a relatively low-toxic somatic antigen like OEP, and detoxified virulence factors of $P$. aeruginosa might appear to be a better approach in the prevention 
Table 2. WACCTHES OF PEUDOHONAS MERUGIMOSA

\begin{tabular}{|c|c|c|c|}
\hline \multicolumn{3}{|c|}{ Vacoine } & \multirow{2}{*}{$\begin{array}{l}\text { Protective activity aganst experimental } \\
\text { infection or in patients }\end{array}$} \\
\hline Compostion & Spectificity & Dose & \\
\hline Lis & monovalent & $.50 \mathrm{ng} / \mathrm{kg}$ & $\begin{array}{l}\text { Protective for normal mice against } 10 \\
\mathrm{LO}_{50}{ }^{*} \mathrm{~s} \text { of } \mathrm{PR}\end{array}$ \\
\hline ; & monova lent & $300 \mathrm{wg} / \mathrm{kg}$ & $\begin{array}{l}\text { Protective against lethal PA infection } \\
\text { in granulacytopenic dogs }\end{array}$ \\
\hline \multirow[t]{3}{*}{$"$} & $\begin{array}{l}\text { polywalent: } \\
7 \text { imtultinotypes }\end{array}$ & $250 \mathrm{lg} / \mathrm{kg}$ & $\begin{array}{l}\text { Protective in burn patients wher given } \\
\text { in combination with p-globulin against } P \text { a }\end{array}$ \\
\hline & & & $\begin{array}{l}\text { Protective activity uncertain in leukenic } \\
\text { patients, frequent adverse reactions }\end{array}$ \\
\hline & & & No protection in cystic fibrosis patients \\
\hline \multirow[t]{3}{*}{ is } & $\begin{array}{l}\text { polyvalent: } \\
16 \text { serotypes }\end{array}$ & ca $260 \mathrm{pg} / \mathrm{kg}$ & $\begin{array}{l}\text { Protection of normal mice against lethall } \\
\text { pA infection }\end{array}$ \\
\hline & & $\mathrm{ca} 400-300$ wg/kg & $\begin{array}{l}\text { Protection of guinea pigs against experi- } \\
\text { mental PA pneumonia }\end{array}$ \\
\hline & & ca $180 \mathrm{ug} / \mathrm{kg}$ & $\begin{array}{l}\text { Protection of burn patients against PA } \\
\text { fatal septicemia }\end{array}$ \\
\hline QEP & $\begin{array}{l}\text { cominon } P A \\
\text { antigen }\end{array}$ & $1.5 \mathrm{mg} / \mathrm{kg}$ & Protection of nornal mice \\
\hline $\begin{array}{l}\text { OEP } \\
\text { adjuivant }\end{array}$ & & $\begin{array}{l}2 \mathrm{mig} / \mathrm{anima} 1 \\
\text { (mink) }\end{array}$ & $\begin{array}{l}\text { Protection of münk against intranasal PA } \\
\text { challenge }\end{array}$ \\
\hline $\begin{array}{l}\text { OEP } \\
\text { * protease toxoid } \\
\text { + elastase toxoid } \\
\text { + adjuvant }\end{array}$ & & \begin{tabular}{ll|l}
1 & mg & total : \\
1 & mg & 3 mg/aninal \\
1 & mog & (mink)
\end{tabular} & $\begin{array}{l}\text { ca } 25 \text { fold higher resistance of mink } \\
\text { against intranasal challenge with PA than } \\
\text { after immunization with } 1 \text { mg oEP } \\
\text { + adjuvant alone }\end{array}$ \\
\hline $\begin{array}{l}\text { ofp } \\
\text { + motease toxold } \\
\text { + elastase hoxold } \\
\text { * adjuvant }\end{array}$ & & 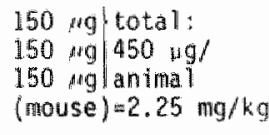 & $\begin{array}{l}\text { Protection of burned mice against PA } \\
\text { challenge } \\
\text { g }\end{array}$ \\
\hline Polysaccharide & $\begin{array}{l}\text { Serotype- } \\
\text { specific }\end{array}$ & $2500 \mu g / \mathrm{kg}$ & $\begin{array}{l}\text { Protection of normal mice against PA } \\
\text { challenge }\end{array}$ \\
\hline
\end{tabular}

Abbreviations used in table: LPS: Tipopolysaccharide; PA: Pseudononas aeruginosa; 0EP: ariginal endotoxin protein. 
of debilitated patients from pseudomonas septicemia.

It is questionable whether cystic fibrosis patients will benefit from immunization with either somatic or extracellular antigens of $P$. aeruqinosa. Antibodies to different pseudomonas antigens were found in the serum of $P$. aeruginosa colonized patients and high concentrations of IgA antibodies were present in their sputum (62). The antibodies presumably were of no benefit since a high number of different serum antibodies to $P$. aeruginosa ant $i-$ gens was associated with a poor prognosis of the colonized patient (21). Nevertheless it is suggested that $P$. aeruginosa colonization might be prevented in young cystic fibrosis patients by local immunization (59). A better understanding of the factors that predispose cystic fibrosis patients to chronic $P$. aeruginosa infections may help to find the best way to protect these patients from frequently fatal pseudomonas pneumonia.

\section{LITERATURE}

1. Abe, C, H. Shionoya, Y. Hirao, K. Okada, and J.Y. Homma. 1975. Common protective antigen (DEP) of Pseudomonas aeruginosa. Japan. J. Exp. Med. 45: 355-359.

2. Abe, C., K. Tanamoto, and J.Y. Homma. 1977. Infection protective property of the common antigen (OEP) of Pseudomonas aeruginosa and its chemical composition. Japan. J. Exp. Med. 47: $393-402$.

3. Alexander, J.W., and M.W. Fisher. 1974. Immunization against pseudomonas in infection after thermal injury. J. Infect. Dis. 130, Suppl.: 152-158.

4. Bartell, P.F., and A. Krikszens. 1980. Influence of anti-slime glycoprotein serum on the interaction between Pseudomonas aeruginosa and macrophages. Infect. Immun. 27: 777-783.

5. Bennett, J.V. 1974. Nosocomial infections due to pseudomonas. J. Infect. Dis. 130, Suppl.:4-7.

6. Bjorn, M.J., M.L. Vasil, J.C. Sadoff, and B.H. Iglewski. 1977. Incidence of exotoxin production by pseudomonas species. Infect. Immun. 16: 362-366.

7. Bjorn, J.J., O.R. Pavlovskis, M.R. Thompson, and B.H. Iglewski. 1979. Production of exoenzyme 5 during Pseudomonas aeruginosa infections of burned mice. Infect. Immun. 24: $837-842$

8. Callahan, L.T., III. 1976. Pseudomonas aeruginosa exotoxin: purification by preparative polyacrylamide gel electrophoresis and the development of a highly specific antitoxin serum. Infect. Immun. 14: 55-61.

9. Cicmanec, J.F., and I.A. Holder. 1979. Growth of Pseudomonas aeruginosa in normal and burned skin extract: role of extracellular proteases. Infect. Immun. 25: 477-483. 
10. Cross, A.5., J.C. Sadoff, B.H. Iglewski, and P.A. Sokol. 1980. Evidence for the role of toxin $A$ in the pathogenesis of infection with Pseudomonas aeruginosa in humans. J. Infect. Dis. 142: $538-54 \overline{6}$.

11. Dimitracopoulos, G., J.W. Sensakovic, and P.F. Bartel1. 1974. Slime of Pseudomonas aeruginosa: in vivo production. Infect. Immun. 10: $152-156$.

12. Dimitracopoulos, G., and P.F. Bartell. 1980. Slime glycolipoproteins and the pathogenicity of various strains of Pseudomonas aeruginosa in experimental infection. Infect. Immun. 30: $402-408$.

13. Dyke, J.W., and Berk, R.S. 1973. Comparative studies on Pseudomonas aeruginosa endotoxin. 2. Allg. Mikrobiol. 13: $307-313$.

14. Fisher, M.W., H.B. Devlin, and F.J. Gnabasik. 1969. New immunotype scheme for Pseudomonas aeruginosa based on protective antigens. J. Bacteriol. 98: 835-836.

15. Gray, L., and A. Kreger. 1979. Microscopic characterization of rabbit lung damage produced by Pseudomonas aeruginosa proteases. Infect. Immun. 23: 150-159.

16. Greer, G.G., and F.H. Milazzo. 1976. Pseudomonas aeruginosa lipopolysaccharide: factors influencing toxicity for isolated mitochondria and endotoxin properties. Can. J. Microbiol. 22: 800-807.

17. Habs, I. 1957. Untersuchungen ueber die D-Antigene von Pseudomonas aeruginosa. Zeitschr. Hyg. 144: 218-228.

18. Hannessian, S., W. Regan, D. Watson, and T.H. Haskell. 1971. Isolation and characterization of antigenic components of a new heptavalent pseudomonas vaccine. Nature (London) New Biol. 229: 209-210.

19. Harvath, L., and B.R. Andersen. 1976. Evaluation of typespecific and non-type-specific pseudomonas vaccine for treatment of pseudomonas sepsis during granulocytopenia. Infect. Immun. 13: 1139-1143.

20. Harvath, L., B.R. Andersen, and H.J. Amirault. 1976. Passive immunity against pseudomonas sepsis during granulocytopenia. Infect. Immun. 14: 1151-1155.

21. Hojiby, N., E. Winge Flensborg, B. Beck, B. Friis, 5. Vidar Jacobson, and L. Jacobsen. 1977. Pseudomonas aeruginosa infection in cystic fibrosis. Diagnostic and prognostic significance of Pseudomonas aeruginosa precipitins determined by means of crossed immunoelectrophoresis. Scand. J. Resp. Dis. $58: 65-79$.

22. Høiby, N., J.B. Hertz, and D. Sompolinsky. 1980. Antibody response in patients with Pseudomonas aeruginosa infection to a "common antigen" from p. aeruginosa analysed by means of quantitative immunoelectrophoresis methods. Acta Path. Microbiol. Scand. Sect. C 88: 149-154. 
23. Holder, I.A., and C.G. Haidaris. 1979. Experimental studies of the pathogenesis of infections due to Pseudomonas aeruginosa: extracellular protease and elastase as in vivo virulence factors. Can. J. Microbiol. 25: 593-599.

24. Homma, J.Y., C. Abe, K. Tanamoto, Y. Hirao, K. Morihara, H. Tsuzuki, R. Yanagawa, E. Honda, Y. Aoi, Y. Fujimoto, M. Goryo, N. Imazeki, H. Noda, A. Goda, S. Takeuchi, and T. Ishihara. 1978. Effectiveness of immunization with single and multicomponent vaccines prepared from a common antigen (OEP), protease and elastase toxoids against hemorrhagic pneumonia in mink due to $P$. aeruginosa. Japan. J. Exp. Med.: 111-133.

25. Homma, J.Y. 1980. Roles of exoenzymes and exotoxin in the pathogenicity of Pseudomonas aeruginosa and the development of a new vaccine. Japan. J. Exp. Med. 50: 149-165.

26. Iglewski, B.H., and D. Kabat. 1975. NAD-dependent inhibition of protein synthesis by Pseudomonas aeruginosa toxin. Proc. Natl. Sci. U.S.A. 72: 2284-2288.

27. Iglewski, B.H., P.V. Liu, and D. Kabat. 1977. Mechanism of action of Pseudomonas aeruginosa exotoxin $A$ : adenosine diphosphate-ribosylation of mammalian elongation factor 2 in vitro and in vivo. Infect. Immun. 15: 138-144.

28. Iglewski, B.H., J. Sadoff, M.J. Bjorn, and E.S. Maxwell. 1978. Pseudomonas aeruginosa exoenzyme $\mathrm{S}$ : an adonosine diphosphate ribosyltransferase distinct from toxin A. Proc. Nat1. Acad. Sci. U.S.A. 75: 3211-3215.

29. Jagger, K., M.M. Nickol, and C.B. Saelinger. 1980. Resistance of exotoxin A to purified pseudomonas protealytic enzymes. Infect. Immun. 28: 746-752.

30. Jones, R.J., E.A. Roe, E.J.L. Lowbury, J.J. Miler, and J.F. 5pilsbury. 1976. A new pseudomonas vaccine: preliminary trial on human volunteers. J. Hyg., Camb. 76: 429-439.

31. Jones, R.J., E.A. Roe, and J.L. Gupta. 1979. Controlled trials of a polyvalent pseudomonas vaccine in burns. Lancet: 977-983.

32. Jones, R.J., E.A. Roe, J.L. Gupta. 1980. Controlled trial of pseudomonas immunoglobulin and vaccine in burn patients. Lancet: $1263-1265$.

33. Kawaharajo, K., and J.Y. Homma. 1977. Effects of elastase, protease, and common antigen (OEP) from Pseudomonas aeruginosa on protection against burns in mice. Japan. J. Exp. Med. 47: 495-500.

34. Kazemierowski, J.A., H.Y. Reynolds, J.C. Kauffman, W.A. Durbin, R.G. Graw, and H.B. Devlin. 1977. Experimental pneumonia due to Pseudomonas aeruginosa in leukopenic dogs: prolongation of survival by combined treatment with passive antibody to pseudomonas and granulocyte transfusions. J. Infect. Dis. 135: 438-446. 
35. Liu, P.V. 1979. Toxins of Pseudomonas aeruginosa: 63-88. In R.G. Doggett (ed.), Pseudomonas aeruginosa: Clinical manifestations of infection and current therapy. Academic Press, New Yark.

36. Lynn, M., J.W. Sensakovic, and P.F. Bartell. 1977. In vivo distribution of Pseudomonas aeruginosa slime glycoprotein: association with 1eukocytes. Infect. Immun. 15: 109-114.

37. Mäkelä, P.H., and H. Mayer. 1976. Enterobacterial common antigen. Bacteriol. Rev. 40: 591-632.

38. Miler, J.M., J.F. Spilsbury, R.J. Jones, E.A. Roe and E.J.L. Lowbury. 1977. A new polyvalent pseudomonas vaccine. J. Med. Microbiol. 10: 19-27.

39. Morihara, K., H. Tsuzuki, and K. Oda. 1979. Protease and elastase of Pseudomonas aeruginosa: inactivation of human plasma $\alpha_{1}$-proteinase inhibitor. Infect. Immun. 24: 188-193.

40. Nonoyama, S., H. Kojo, Y. Mine, M. Nishida. S. Goto and S. Kuwahara. 1979. Inhibitory effect of Pseudomonas aeruginosa on the phagocytic and killing activities of rabbit polymorphonuclear leukocytes: purification and characterization of an inthibitor of polymorphonuclear leukocyte function. Infect. Immun. 24: 394-398.

41. Nonoyama, S., H. Kojo, Y. Mine, M. Nishida, 5. Goto, and 5. Kuwahara. 1979. Inhibitory effect of Pseudomonas aeruginosa on the phagocytic and killing activity of rabbit polymorphonuclear leukocytes: mechanism of action of a polymorphonuclear leukocyte inhibitor. Infect. Immun. 24: 399-403.

42. Okada, K., K. Kawaharajo, T. Kasai, and J.Y. Homma. 1980. Effects of somatic component of Pseudomonas aeruginosa on protective immunity in experimental mouse burn infection. J. Exp. Med. 50: 53-61.

43. Pavlovskis, O.R., M. Pollack, L.T. Callahan III, and B.H. Iglewski. 1977. Passive protection by antitoxin in experimental Pseudomonas aeruginosa burn infections. Infect. Immun. 18: $596-602$.

44. Pavlovskis, O.R., and B. Wretlind. 1979. Assessment of protease (elastase) as a Pseudomonas aeruginosa virulence factor in experimental mouse burn infection.

45. Pavlovskis, D.R., D.C. Edman, S.H. Leppla, B. Wretlind, L.R. Lewis, and K.E. Martin. 1981. Protection against experimental Pseudomonas aeruginosa infection in mice by active immunization with exotoxin A. Infect. Immun. 32: 681-689.

46. Pennington, J.E. 1974. Preliminary investigations of Pseudomonas aeruginosa vaccine in patients with leukemia and cystic fibrosis. J. Infect. Dis. 130, Suppl.: 159-162.

47. Pennington, J.E., H.Y. Reynolds, R.E. Wood, R.A. Robinson, and A.S. Levine. 1975. Use of a Pseudomonas aeruginosa vaccine in patients with acute leukemia and cystic fibrosis. Am. J. Med. 58: $629-636$. 
48. Pennington, J.E. 1979. Immunotherapy of Pseudomonas aeruginosa infection, p. 191-217. In R.E. Doggett (ed.), Pseudomonas aeruginosa. Clinical manifestations and current therapy. Academic Press, New York.

49. Pennington, J.E. 1979. Lipopolysaccharide pseudomonas vaccine: efficacy against pulmonary infection with Pseudomonas aeruginosa. J. Infect. Dis. 140: 73-80.

50. Pennington, J.E., and D. Kuchmy. 1980. Mechanism for pulmonary protection by lipopolysaccharide pseudomonas vaccine. J. Infect. Dis. 142: 191-198.

51. Pier, G.B., H.F. Sidberry, S. Zolyomi, and J.C. Sadoff. 1978. Isolation and characterization of a high-molecular-weight polysaccharide from the slime of Pseudomonas aeruginosa. Infect. Immun. 22: 908-918.

52. Pier, G.B., H.F. Sidberry, and J.C. Sadoff. 1978. Protective immunity induced in mice by immunization with high-molecularweight polysaccharide from Pseudomonas aeruginosa. Infect. Immun. 22: 919-925.

53. Pollack, M., L.T. Callahan III, and N.S. Taylor. 1976. Neutralizing antibody to Pseudomonas aeruginosa exotoxin in human sera: evidence for in vivo toxin production during infections. Infect. Immun. 14: 942-947.

54. Pollack, M., and N.S. Taylar. 1977. Serum antibody to Pseudomonas aeruginosa exotoxin measured by a passive hemagglutination assay. J. Clin. Microbio1. 6: 58-61.

55. Pollack, M., N.S. Taylor, and L.T. Callahan III. 1977. Exotoxin production by clinical isolates of Pseudomonas aeruginosa. Infect. Immun. 15: 776-780.

56. Pollack, M., and S.E. Anderson. 1978. Toxicity of Pseudomonas aeruginosa exotoxin A for human macrophages. Infect. Immun. 19: $1092-1096$.

57. Pollack, M., and L.5. Young. 1979. Protective activity and antibodies to exotoxin $A$ and lipopolysaccharide at the onset of Pseudomonas aeruginosa septicemia in man. J. Clin. Invest. $63: \overline{276-286}$

58. Pollack, M. 1980. Pseudomonas aeruginasa exotoxin A. New Eng. J. Med. 302: 1360-1362.

59. Reynolds, H.Y., A.S. Levine, R.E. Wood, C.H. Zierdt, D.C. Dale, and J.E. Pennington. 1975. Pseudomonas aeruginosa infections: persisting problems and current research to find new therapies. Ann. Intern. Med. 82: 819-831.

60. Saelinger, C.B., K. Snel1, and S.A. Holder. 1977. Experimental studies on the pathogenesis of infections due to Pseudomonas aeruginosa: direct evidence for toxin production during pseudomonas infection of burned skin tissues. J. Infect. Dis. 136: 555-561. 
61. Sanai, Y., K. Takeshi, J.Y. Homma, and H. Kamata. 1978. Production of exotoxin, protease and elastase of Pseudomonas aeruginosa strains isolated from patients" and environmental specimens. Japan. J. Exp. Med. 48: 553-556.

62. Schítz, P.0., N. Holby, H. Permin, and A. Wiik. 1979. IgA and IgG antibodies against surface antigens of Pseudomonas aeruginosa in sputum and serum from patients with cystic fibrosis. Acta Path. Microbio1. Scand. Sect. C 87: 229-233.

63. Schultz, D.R., and K.D. Miller. 1974. Elastase of Pseudomonas aeruginosa: inactivation of complement components and complement-derived chemotactic and phagocytic factors. Infect. Immun. 10: 128-135.

64. Sensakovic, J.W., and P.F. Bartell. 1974. The slime of Pseudomonas aeruginosa: biological characterization and possible role in experimental infection. J. Infect. Dis. 129: 101-109.

65. Snell, K., I.A. Holder, S.A. Leppla, and C.B. Saelinger. 1978. Role of exotoxin and protease as possible virulence factors in experimental infections with Pseudomonas aeruginosa. Infect. Immun. 19: 839-845.

66. Sompolinsky, D., J.B. Hertz, N. Høiby, K. Jensen, B. Mansa, and 7. Samara. 1980. An antigen common to a wide range of bacteria. I. The isolation of a "common antigen" from Pseudomonas aeruginosa. Acta Path. Microbiol. Scand. Sect. B 8B: $\overline{143-149 .}$

67. Tapper, M.L., and D. Armstrong. 1974. Bacteremia due to Pseudomonas aeruginosa complicating neoplastic disease: a progress report. J. Infect. Dis. 130, Suppl.: 14-23.

68. Walker, H.L., C.G. McLeod, S.H. Leppla, and A.D. Mason. 1979. Evaluation of Pseudomonas aeruginosa toxin $A$ in experimental rat burn wound sepsis. Infect. Immun. 25: 828-830.

69. Wretlind, B., and T. Kronevi. 1978. Experimental infections with protease-deficient mutants of Pseudomonas aeruginosa in mice. J. Med. Microbiol. 11: 145-154.

70. Young, L.S, and D. Armstrong. 1972. Human immunity to Pseudomonas aeruginosa. I. In vitro interaction of bacteria, polymorphonuclear leukocytes, and serum factors. J. Infect. Dis. $126: 257-276$.

71. Young, L.S. 1980. The role of exotoxins in the pathogenesis of Pseudomonas aeruginosa infections. J. Infect. Dis. 142: 626630 . 


\title{
Ribonuclease-Sensitive Ribosomal Vaccine of Pseudomonas aeruginosa
}

\author{
RINSKE GONGGRIJP, WIL J.H. A. MULLERS, PAIL J. M. R. IEMMFNS, AND C. P. A. WAN \\ BOVEN \\ Department of Medical Microbiology, State University of Limburg. Madstricht. The Netheriands
}

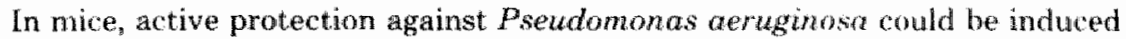
with two fractions derived from a crude preparation of ribosomes from $P$. aeruginosa. The two fractions were obtained by gel filtration chromatography of the crude ribosomal preparation on Sepharose CL-2B. In fraction I, less than $1 \%$ of the ribonucleic acid (RNA) applied to the collumn was recovered. Fraction II contained RNA and protein in a ratio of 1.94 . The presence of ribosomes in this fraction was confirmed by analysis on a sucrose density gradient. The protection by fraction I was not affected by treatment with ribonuclease; in contrast, incubation of fraction II with ribonuclease completely abolished active protection. Fraction I contained lipopolysaccharide (LPS) as was indicated by the presence of 2-keto-3-deoxyoctonic acid. No LPS was found in fraction II. The adjuvant dimethyl dioctadecyl ammonium bromide enhanced the protection by fraction $\mathrm{II}_{\text {; }}$ however, immunity by a low dose of fraction I was abolished by dimethyl dioctadecyl ammonium bromide. Protection by fractions I and II appeared to be restricted to the homologous serotype of $P$. aeruginosa. These results indicate that RNA is required for protection by fraction II. Active protection by fraction I is likely due to LPS.
\end{abstract}

Infections with antibiotic-resistant Pseudom. onas aeruginosa remain a serious problem for compromised patients, such as burn patients, patients with malignancies, and children with cystic fibrosis. Clinical trials with vaccines containing lipopolysaccharide (LPS) of $P$. aeruginosa have indicated that burn patients may be protected from Pseudomonas bacteremia by aclive immunization (1). However, vaccination with these preparations is associated with a high incidence of side effects (14) probably due to the ioxicity of LPS.

In 1965 Youmans and Youmans (22) reported that ribosomal preparations of Mycobacterium tuberculosis could be highly immunogenic. Since then, ribosomal vaccines have been prepared from many bacterial species (6), including $P$. aeruginosa $(12,18)$. Ribosomal vaccines of several microorganisms le.g., $M$. tuberulosis, Salmonelta typhimurium. Streptococcus pneu. moniae) showed advantages over more conventional vaccines. The ability of the pneumococcal ribosomal vaccine to induce protection against other serotypes is of special interest (4). The immunogenic principle of the ribosomal vaccines has not been ularified. Youmans and Youmans (2:3) conduded that ribonucleic acid (RNA) of M. Tuberculosis is the effective immunogen. Siwendsen and Johnson (19) reported that ribosonal protein of 5 . pmetumontae is required "and
Feit and Tewari (7) showed that both RNA and protein of Histoplasma capsulatum were necessary for protection. In the case of Vibrio cholerae, Jensen et al. (11) showed that an exoge nous contaminant in ribosomal vaccines of $V$. cholerae was responsible for immunity. Andron et al. (2) have suggested that ribosomal RNA of Francisello tularensis plays a structural or a carrier role in the presentation of a somatic antigen.

The type of immunity may depend on the microorganism from which the ribosomal vaccine was prepared. A humoral immunity was evoked by vaccint tion with ribosomal vaccines prepared from $S$. pnetumonicae, whereas ribosomal vaccines of $S$ t $y$ phimurium were reported to induce cellular imnunity (6).

Ribosomal vaccines of $P$. aeruginosa have been described by several investigators $(12,18)$. Lieberman $(12,13)$ reported that serum-mediated protection could be obtained with purified ribosomes. The protective capacity of this ribosomal vaccine was not diminished after treatment with ribonuclease (RNage) or trypsin (12). In addition. Lieberman (15) did not find evidence for the presence of LPS because antibodies induced by the purified ribosomal vacrine in rabbits did not agghtinate LPS.

In the present paper we present evidence that active protection in nice against $P$. areruginosa 


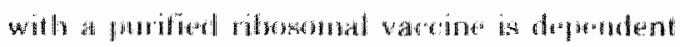
(I)

\section{MATHCLAS ANOH METHOHS}

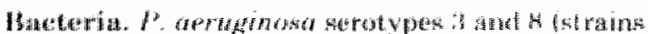

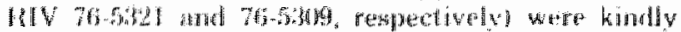
provided by i. Borm. Nationat Instidute of Public

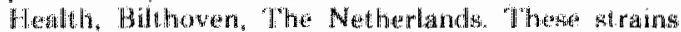
were isolated from clinical specimens in 1976 . Susper. sions of bquteria were stored in small portions at $-70^{6} \mathrm{C}$. Strain KIV $76 \times 521$ (serotype a) was used in all wperiments as the challenging organism and for the preparation of the waccines, except in the experiments conceming the specifieny of protection.

Mice. Outbred male and finale CobsE Swiss mice (body awd atht 18 to 20 g) were purchased from "TNO, Central Instutute for the Breeding of Laboratory Antmals, Zoist, The Nethertands.

Crude ribosomal preparation from $P$ aruginosa. Bacteria were grown in 8 liters of Trypticase soy broth (BBL. Microbiology Systems, Cockeyswille, Md a $37^{3} C^{4}$ with aeration, unt il the concentration of Hoacteria was $1 \times 10^{8}$ to $2 \times 10^{4}$ bacteria per $\mathrm{ml}$. Bateria were harvested by contrifugation and washed

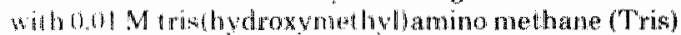
baffer $(\mathrm{pH}$ 7.2) contaming $0.1 \mathrm{M} \mathrm{KCl}$ and $0.915 \mathrm{M}$ MgCl. ITKM bufferi. The bacterial pellet was frozen, and the henteria were broken in a cold Hughes pressure cell. The broken cell paste was suspended in lon m of TTM lafter, containing deoxyribonuclease (t). Merek AC, 1)ametudt "Germany). This suspuston was incubated for 15 min at $177^{\circ} \mathrm{C}$ and subsequently entrifuged for $20 \mathrm{~min}$ at $30,000 \times \mathrm{g}$ an 4 (C. The pellet was discarded. and the supernatant was centrifuged lor 20 min at $45,000 \times g$. Four fifths of the supernatant was carefully removed and filcered through a $0.2-\mu \mathrm{m}$ Sartorus filter. "The fill rate was centrifuged for $2.5 \mathrm{~h}$ at $180,000 \times$ \&. Finally, the resulting pellet containing the ribosomes was resuspended in TKM buffer at a concentration of $100 \mathrm{mg}$ (wet. weight) $/ \mathrm{mll}$ (crude ribosomall preparationy. The crude ribosomal preparation was aged for column chromatography. Samples to be used for inmunizations were stored at $-70^{\circ} \mathrm{C}$ at a concentwation of $50 \mathrm{mg}$ (wetwe who $/ \mathrm{ml}$. Portions were lyophilized for the determination of the dry weight. The values of the dry wenght were corrected for the amount of salt prisent in the diluent.

Molecular sieve chromatography: preparation of linetions I and II. Sepharose CD, $2 \mathrm{~B}$ (Pharmacia, (appota, siveden) was equilibrated at $4 \mathrm{C}$ with $7 \mathrm{KM}$ butfon comtaining I $\mathrm{M} \mathrm{NH}$, Cl. The crude ribosomal promenption $(14$ to $26 \mathrm{ml})$ was applied to a sepharose

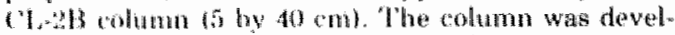

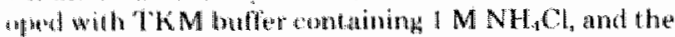
absuthance of the alute was measured at 540 and 260

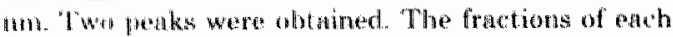

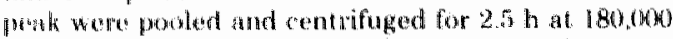
$\times$ \&. "The pellet of fration 1 was suspended at a comentuation of $20 \mathrm{mg}$ (wet weight)/nil in $0.005 \mathrm{M}$

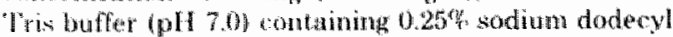
sultate and fillered through a $0.2-\mu \mathrm{m}$ sartorius falter. A port of the filtered fraction I was stored in small fomions and another pari was lyophilized, resus pended in toncentration of $10 \mathrm{mg}$ (dry weight)/ml. and stored at $-70^{\circ} \mathrm{C}$. The pelled of fraction II was

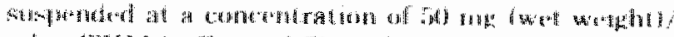

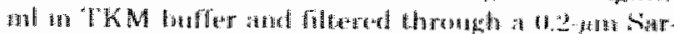

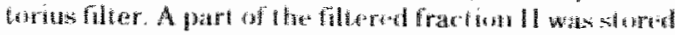

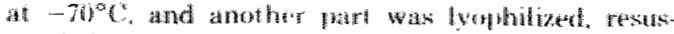

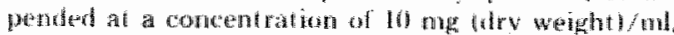
and scored a -70 c:

Sterility. Sterility of all vaccines was insured by inoculating tubes (Trypticase soy broth and plates (Trypticase soy agar) with a drop of the vaccun. If there was no growth after $48 \mathrm{~h}$, the waceine was considered to be sterile.

Chemical analyses. The amount of deoxyribonuclleic acid (DNA) was determined by the diphenyla mine method of Dische, according to the modifiction of Burton (5) whth calf thymus DNA (Merck) as the standard. The amount of RNA was estimated by the orcinol method uf Herbert et al. (9), using yeast RNA (Buehringer Mannheim Corp., Mannheim, West Germany) as the standard. The concentration of protein was determined by the folin method modified by Hartree (8) with bovine serum albumin ats the statdard. The amount of phospholipid was determined as follows ( 16 . Fraction I was dialyzed against $0.005 \mathrm{M}$ Tris buffer (pH 7.0) to remove the excess of sodtiun dodecyll sulfate. Samples (1 $\mathrm{ml}$ ) of the crude ribosomal preparation and of fractions 1 and II containing 2,2 . and is $\mathrm{mg}$ (dry weight), respectively, were extracted three limes with 3.75 mil of a mixture of methanot and chloroform (2: I vol/wol) and centrifuged. The fonbined supernat ants we dried under nitrogem at $37^{\circ} \mathrm{C}$. "Whe residwes were extracted threg times with $3 \mathrm{ml}$ of chloroform. The cambined supernatints were drited under nitrogen at $37^{\circ} \mathrm{C}$, and the residues were hydrolyzed at $180^{\circ} \mathrm{C}$ with $0.5 \mathrm{ml}$ of $72 \%$ perchlorio acid unt the digest was colorless. The hydrolysate was cooled to noom temperature, and $4.1 \mathrm{ml}$ of diafilled water. 0.2 ml of $5 \%$ ammonium molybdate, and $10,2 \mathrm{ml}$ of Fiske Subbarow reagent, were added. The mixture was. heated for $15 \mathrm{~min}$ at $100^{\circ} \mathrm{C}$. and finally the aborbance was measured at $830 \mathrm{~nm}$. Inorganic phosphate wats used as the standard. It was assumed that $1 \mathrm{mg}$ of phospholipid contained $40 \mu \mathrm{g}$ of phosphorus. LPS was estimated by the determination of the 2-keto-3-dleoxyoctonate (KDO) as follows. A sample $(4 \mathrm{mg}$ 『dry weight () was hydrolyzer with $0.014 \mathrm{NH} S \mathrm{HO}_{\text {, for } 20}$ min at $100^{\circ} \mathrm{C}$. KDO was determined by the thiobar biturie acid method of Weissbach and Hurwitz (20) with $\mathrm{KDO}$ (Sigma Chernical $\mathrm{Co}$ ) as the standard. The amount of L.PS was calculated by assuming that LPS contained $5 \%$ KDO 100 . The lower linit of detection was $3 \mu \mathrm{g}$ of $1 \mathrm{PS}$.

Sucrose density analysis. A linear sucrose gradient from 10 to 30 cos made in $0.05 \mathrm{M}$ Tris bulfer (jH 7.2) containing $0.1 \mathrm{M} \mathrm{KCl}$ and either $1 \mathrm{mM} \mathrm{MgCl}$ of $15 \mathrm{mM} \mathrm{MgCl}$. Samples of $1 \mathrm{ml}$ contaning $4 \mathrm{mg}$ of material wet weight were layered on top of the gradient. Centrifugrtion was carried oul for $16 \mathrm{~h}$ at $20,000) \mathrm{rpm}$ in an SW 40 rotor (Becknan) a $4^{\circ} \mathrm{C}$. Frac. tions of $0.5 \mathrm{mil}$ were collected, and the absorbance a 260 and $280 \mathrm{~nm}$ was determined.

Vaccination. Mice were inmumized with a single. subcutameous injection of either $0.1 \mathrm{ml}$ of vaccine in TKM buffer or with $0.2 \mathrm{ml}$ of a mixture of the vaccine and dimethyl doctadecyl anmonium bromide (DDA; Eastman Kodak Co. Rochester, N.Y.) (I volume of 
vath a

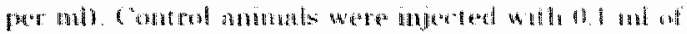

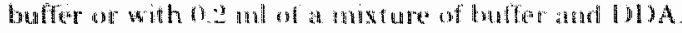

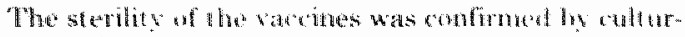
the on lryphotist soy agar plates.

Challenge, $P$ aerughosid was harrested aft tou. luring exernight in Trypticase soy broth and wished twice with salline. Six days after the varcination, the mice were challenged by an intraperitoneal injection of 0.1 ml of the suspension of bacteria. Experiments with mice, vacinated with the crude ribosomal preparation or with fractions 1 and II and challenged after different time intervals, showed that time interval of 6 days between vaccination and challenge resulted in optimal data on protection. The number of bacteria was determined by measuring the turbidity at $540 \mathrm{~nm}$ and by couming the colony-forming units. The $50 \%$ lethal dose (LD) was determined by the method of Reed and Muench (17). The $\mathrm{LD}_{5,}$ for strain $76-5321$ Iserorype 3 was $2 \times 10$ bacturia. The $\mathrm{LD}_{\text {i }}$ for strain $76-5309$ (serotype 8 ) was $1.5 \times 10^{\circ}$ bacteria. Deaths, which occurred principally within 2 days after chal. lenge, werte recordied 14 davs after challenge.

Treatment with RNase and with pronase and trypsiln. Before enoymatic treatment, fractions I and 11 were dialyzed against $0,005 \mathrm{M}$ ethylenediaminetet. raacetio acid $(\mathrm{pH} 7.2)$ overnight at $4^{\circ} \mathrm{C}$ followed by diallysis atainst distilled water for 1 ly. LNase treatment was performed for 1 h at $37^{\circ} \mathrm{C}$, after the addition

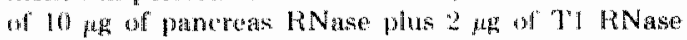
(Bothringer Mannheims to $2 \mathrm{~m}$ of fraction II (4n) ug of dry material). Sequential retment with pronase $\mathbb{E}$ (Merck) and trypsin (Boebringer Mannheim) was car ried out as follows. A $2 \mathrm{ml}$ amount of fraction 11,400 ug of dry material) and $2 \mathrm{ml}$ of fraction $\mathrm{I}(20) \mu \mathrm{g}$ of $\mathrm{dry}$ matelial) were incubated for 30 min at $30^{\circ} \mathrm{C}$ in the presence of $10 \mu \mathrm{g}$ of pronase. Subsequently, $10 \mu \mathrm{g}$ of trypsion was atded to each mixture, and the incubation was condinued for $30 \mathrm{~min}$ at $37^{\circ} \mathrm{C}$.

Statistical evaluation. Significance levels for prolaction were determined by the Fisher exact test as described by Bradley (4).

\section{RESULTS}

Molexular sieve chromatography of the crude ribosomal preparation. The crude ri. bosomal preparation was further purified on Sephadex CL-2B. Two distinct peaks were obtanned (Fig. 1). Fraction I (turbid) eluted in the void volume, whereas fraction II was retarded.

Composition of crude ribosomal preparation, fractions I and II. The amount of DNA, RNA, protein, phospholipid, and LPS per milligram (dry weight) and the ratio of RNA to protein of the crude ribosomal preparation, fractions I and II, are presented in Table 1. The recovery of these constituents of the crude ribosomal preparation after molecular sieve chromatography is shown in Table 2. RNA and protein were the main components of the crude ribosomal preparation. A total of $70 \%$ of the IINA was recovered in fraction II. The ratio of RNA to protein of fraction II was 1.94 , a value consist ent with that of highly purified ribosomal

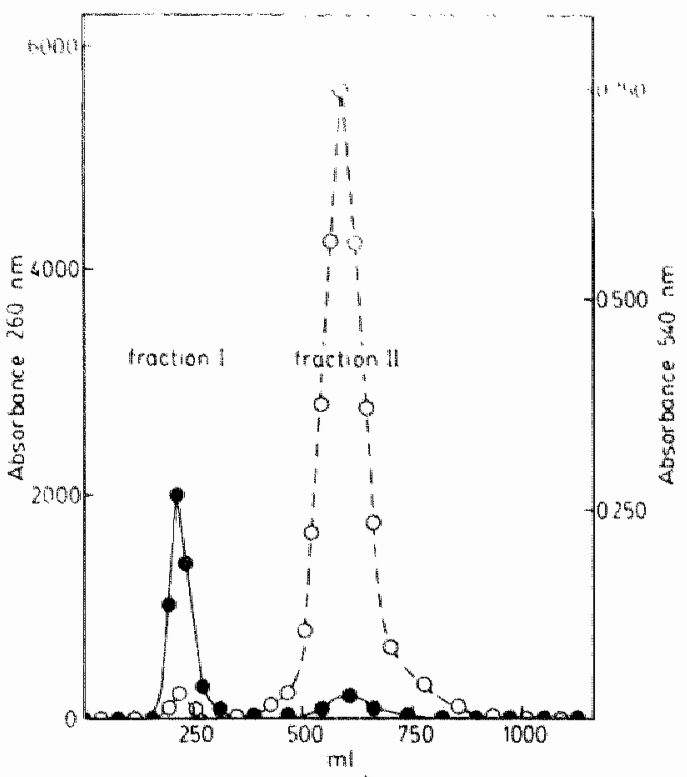

Fili. 1. Molecular siete chromatheraphy of the wade ribosomal prepartion on a sepharose CL.2B

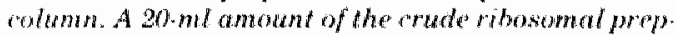
aration, containing $552 \mathrm{mg}$ (dry wetght), was applated to the Sepharowe CL.2B column (5 by $40 \mathrm{~cm}$. The rolumn was developed with TKM buffer contamm IMNH,Cl (O. optocal density at $260 \mathrm{~nm}$ - optiont dexsity at $540 \mathrm{~mm}$ ). The void volume 1 as $220 \mathrm{mt}$ as determined whith dextron blue 2000 .

preparations of bacteria. By sucrose density gra. dient analysis in $15 \mathrm{mM} \mathrm{MgCl}$, a peak of undissociated ribosomes (presumably 705 ) and an additional peak of the $50 \mathrm{~S}$ ribosomal subunit were found in fraction II (Fig. 2B) and in the crude ribosomal preparation (Fig. 2A). In the presence of $1 \mathrm{mM} \mathrm{MgCl}$, the $70 \mathrm{~s}$ ribosomes dissociated into the $50 \mathrm{~S}$ and 308 subunits.

Fraction II contained $8 \mu g$ of phospholipid/mg (dry weight) and less than $0.8 \mu \mathrm{gg}$ of LPS/mg (dry weight). In cont rast, fraction 1 contained 98 $\mathrm{kg}$ of LPS/mg (dry weight) and $76 \mathrm{~kg}$ of phospholipid/mg (dry weight). of the RNA in the crucle ribosomal preparation only $0.7 \%$ was recovered in fraction 1 (Table 2 ).

Protection induced by the crude ribosomal preparation, fractions I and II. AI an inoculum of $3 \mathrm{LD}_{\text {rall }}$ of $P$. aeruginosa, protection was obtained by a single vaccination with the crude ribosomal preparation, and with fractions 1 and II (Table 3). The percentage of survival obtained with fraction II was lower than that with fraction I and with the crude ribosomal preparation. The protective capacity of fraction II could be increased by freeze-drying.

At an inoculum of $4.5 \mathrm{LD} \mathrm{D}_{\mathrm{*} \text {, }}$, protection was obtained with the crudle ribosomal preparation and fraction 1 . Howesper. protection by fraction 


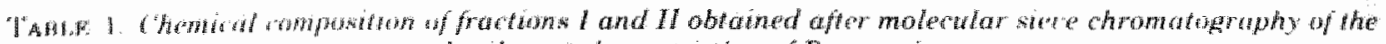
roude ribumonal preparation of $P$. ceruginosa

\begin{tabular}{|c|c|c|c|c|c|c|}
\hline \multirow{2}{*}{$\left.\|^{x}+4\right)$} & \multicolumn{5}{|c|}{ 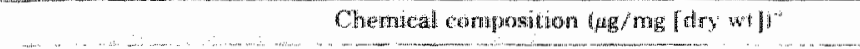 } & \multirow{2}{*}{ WA/protents } \\
\hline & Wh & Irottentin & DNA & Mhospholipid & 1.15 & \\
\hline Crume ribugental & 482 & 55 & 2.4 & 32 & 33 & 0.85 \\
\hline Fraction & 23 & 288 & $\mathrm{ND}^{5}$ & 76 & 98 & 0.07 \\
\hline Gratron II & 618 & 39 & ND & 8 & $<08$ & 1.94 \\
\hline
\end{tabular}

" Bact number represents the nedin yaluo of the determinations of three separate preparations.

ND, Not detectable.

THAH, 2. Hecovery of the different comstituents of

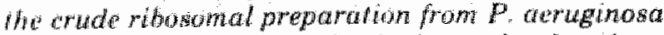
in fractions $I$ and II oblatined after molecular steve chromatography

\begin{tabular}{|c|c|c|c|c|c|}
\hline \multirow[b]{2}{*}{ 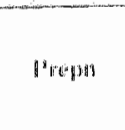 } & \multicolumn{5}{|c|}{ Reocissutery } \\
\hline & Dry & MNA & Protein & 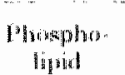 & LPS \\
\hline Findion & libio & 0.7 & 7.8 & 393,4 & 44.6 \\
\hline Fratecion 11 & 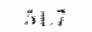 & 199,0 & 29.7 & 11.4 & 0.0 \\
\hline Total & tiา. & 9 & 3,5 & $4+x$ & 4.6 \\
\hline
\end{tabular}

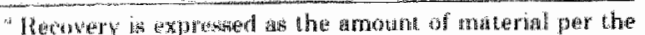
anount of maternit in the arda ribosomal preparat on $\times 100$. Each number represents the mean value of the clecrmination of throe soparate preputrationas.

II and by freeze-dried fraction II could no longer be demonstrated.

Effect of the adjuvant DDA on protection induced by fractions I and II. DDA has recently been reported to enhance the immunogenicity of an RNA-rich vaccine of Listeria mon. ocvfogenes (21). Protection by fraction II $20 \mu \mathrm{g}$ [dry weight]) was markedly enhanced by DDA (Tible 4). In contrast, DDA abolished the protection induced by a low dose of fraction I $(0.2$ Hm (ary weight l). However, a protection by a

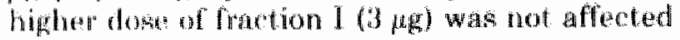
by DIIA (data not shown).

Protection by fractions I and II after treatment with RNase or with pronase and trypsin. "The protection against. $P$. atruginosa induced by fraction I was not affected by incubation of the vaccine with RNase, or with pronase and trypsin (Table 5). Incubation of fraction II with RNase abolished the immunity induced by this vaccine. No significant change in protection was observed when fraction II was treated with pronase and trypsin.

Specificity of the protection by fractions 1 and II. All previous experiments were carried out with vaccines and challenging organisms of serotype 3. Data on survival after heterologous chullenge are presented in Table 6. Fractions I and II obtained from $P$. aeruginosa serotype 3 failed to induce protection against organisms of sisolvpe 8. Vaccines prepared from serotype 8 provided protection against homologous challenge.

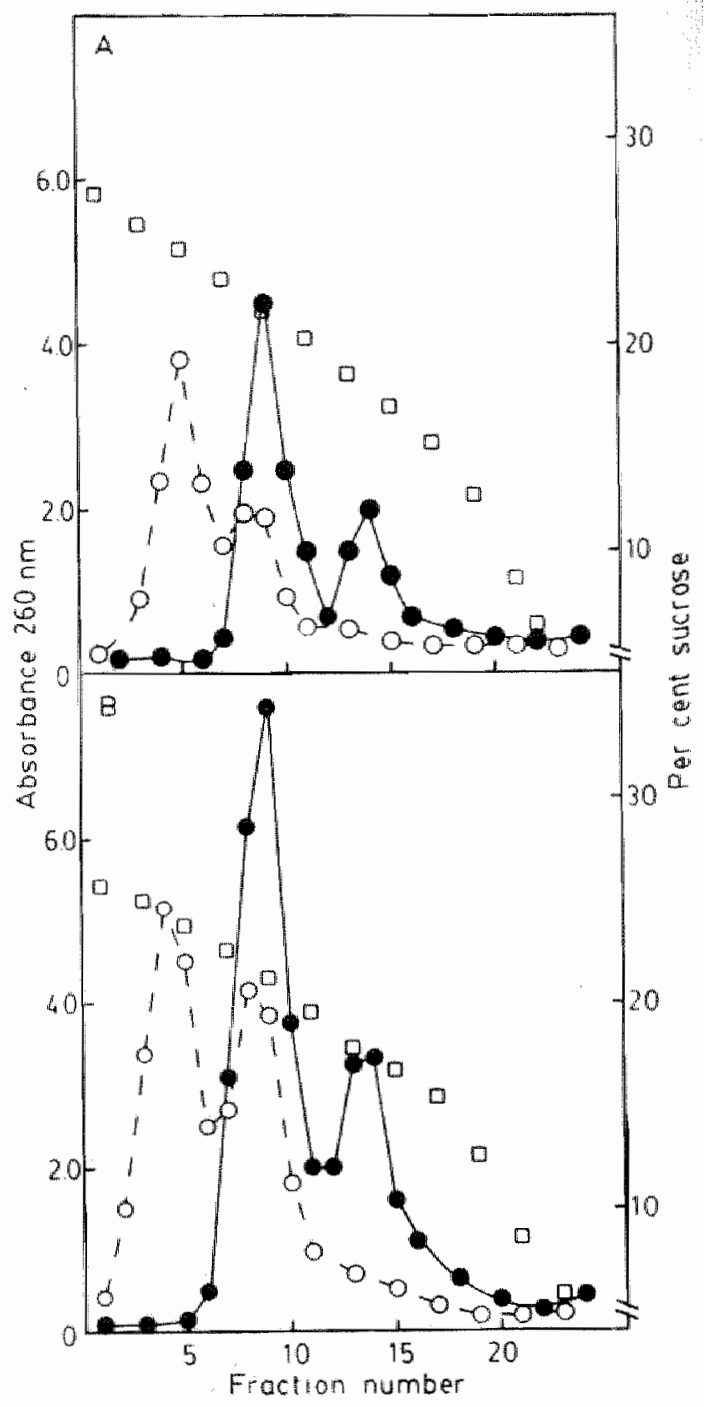

Fia. 2. Sucrose density gradient analysis of the crude ribosomal preparation (A) and of fraction ll (B). A to to 30\% sucrose gradient was made in buffer contaning either 1 or $15 \mathrm{mM} \mathrm{MgCl}$. Centrifugation was carried oul for 16 h at $20,000 \mathrm{rpm}$ at $4^{\circ} \mathrm{C}$. Frar. finms of $0.5 \mathrm{ml}$ were collected. and the absorbance at

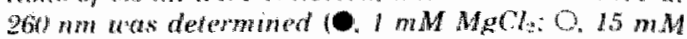
Mecl:D procent sucrase). 


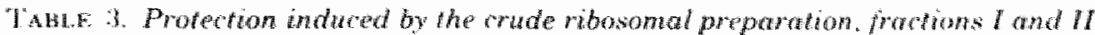

\begin{tabular}{|c|c|c|c|c|c|}
\hline \multirow{2}{*}{ Viacionte } & \multirow{2}{*}{$\begin{array}{c}\text { Dhat } \\
\text { fage wet wh }\end{array}$} & \multicolumn{2}{|c|}{ Sturvitat" at a LDD } & \multicolumn{2}{|c|}{ Sincrivat at $4.5 \mathrm{CD}$} \\
\hline & & s: & p) valuet & $q *$ & IP watue: \\
\hline Butfer & & 7 & & 10 & \\
\hline Crude ribosomal preparation & 200 & 100 & $(<0.001)$ & 90 & $(<0,0) 01)$ \\
\hline Fraction 1 & 200 & 100 & $(<0,001)$ & 95 & $(<0,001)$ \\
\hline Fraction II & 200 & 37 & $(0.005)$ & 10 & $(0.7)$ \\
\hline Fraction II freeze doned & 250 & 70 & $(<0,001)$ & 13 & $(0.5)$ \\
\hline
\end{tabular}

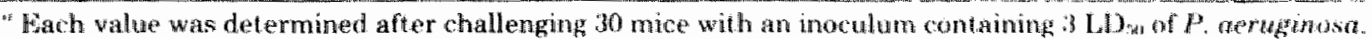

"Fach value was determined after challenging 20 mice with an inoculum containing 4.5 LD of P. aerugunua.

"The $P$ values with respect to the controls were calculated by the fisher test.

TABLE 4. Effect of the adjuvant DDA on the protection induced by fractions I and II

\begin{tabular}{|c|c|c|}
\hline Vaccine & $\begin{array}{c}\text { Dose } \\
(\mu \mathrm{g}[\mathrm{dry} w \mathrm{w}])\end{array}$ & 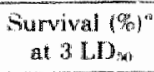 \\
\hline Benfer & & 0 \\
\hline Buffer plus DDA & & 5 \\
\hline Fraction 1 & 0.2 & 90 \\
\hline Fraction I plus DDA & 0.2 & $0(<0.001)$ \\
\hline Fraction II & 20 & 10 \\
\hline Fraction II plus DDA & 20 & $80(<0.001)$ \\
\hline
\end{tabular}

"Fach value was determined after challenging 20 mice with an inoculum containing $3 \mathrm{LD}_{\text {tw }}$ of $P$ aeruginowa. Numbers in parentheses are $P$ values with respect to the correspondung vaccine without DDA, calcwated by the Fisher test.

TABLE 5. Protection by fractions I and II after treatront with RNase. or with promase and trypsin

\begin{tabular}{|c|c|c|}
\hline Vatcoine & 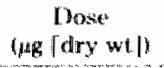 & 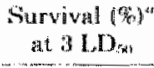 \\
\hline Huffer & & i) \\
\hline finction I & 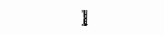 & 95 \\
\hline $\begin{array}{l}\text { Fratuion I Ineated with } \\
\text { RNase }\end{array}$ & 1 & 95 \\
\hline $\begin{array}{l}\text { fraction I treested with pro- } \\
\text { natse and erypsin }\end{array}$ & 1 & 95 \\
\hline Huffer with DDA & & 5 \\
\hline Fraction 1 . wh ThA & 20 & 80 \\
\hline 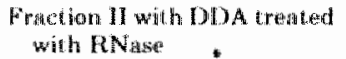 & 20 & $0(<0.001)$ \\
\hline 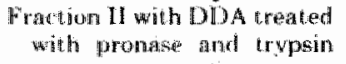 & 20 & $75(0,5)$ \\
\hline
\end{tabular}

"Fach value was determined after chatlenging 20 mice with an indurulum of $3 \mathbb{L}, \mathrm{D}$ a of $P$, aerugimesa. Numbers in parenwhases are $P$ walnes with respect to the corresponding unireated nactine, valculated by the Fisher teat.

\section{DISCUSSION}

Fince the vaccines of $P$. aeruginosa used in clinical trials are associated with a high incidence of side effects (14), ribosomal vaccines might offer a nontoxic alternative preventing the compromised patient from becoming infected with this organism (3). Although effective ribosomal vaccines are prepared from many micro. organisms, the inmunogenic principle of these vaccines has not been fully clarified. The discus-
TABH.F. 6. Splecificify of protection by fractions I and

\begin{tabular}{|c|c|c|c|c|c|}
\hline \multirow{2}{*}{ Vaceine } & \multirow{2}{*}{$\begin{array}{c}\text { Dose } \\
\text { (as fdry wit) }\end{array}$} & \multirow{2}{*}{$\begin{array}{c}\text { Chal } \\
\text { fenging } \\
\text { serotype }\end{array}$} & \multicolumn{3}{|c|}{ Survival at $2.5 \mathrm{LI})_{\text {int }}$} \\
\hline & & & 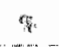 & $n^{\text {nit }}$ & Prolate \\
\hline Buffer & & 8 & $f^{n}$ & 18 & \\
\hline $\begin{array}{l}\text { Framion } 1 \\
\text { seroitype }\end{array}$ & 30 & 8 & 6 & $A t_{0}^{n}$ & $(0,72)$ \\
\hline $\begin{array}{l}\text { Fraction I } \\
\text { serotype } 8\end{array}$ & 50 & a & 100 & $1 \%$ & $\langle<0,01)_{1}$ \\
\hline $\begin{array}{l}\text { Fraction II } \\
\text { serotype } 3\end{array}$ & 50 & 8 & () & $\| 6$ & $(1.0)$ \\
\hline $\begin{array}{l}\text { Fraction } 11 \\
\text { serotype } 8\end{array}$ & 80 & $g$ & $6 \mathrm{H}$ & 15 & $(<0,0) 1)$ \\
\hline
\end{tabular}

"Number of animals.

"P values with respeet to the control were calculated try the fistrer test.

sion on the nature of ribosomal vaccines focuses on whether the immunogenicity of these vaccines is due to an exogenous contaminant or is caused by the ribosomes. The present study provides evidence that the protection by a purified ribosomal vaccine of $P$, aeruginosa is dependent on the presence of RNA.

A crude ribosomal preparation of $P$. caeruginosa was separated into two fractions by molecular sieve chromatography. The first one, fraction $I$, contained high-molecular-weight or aggregated material in which protein. phospho. lipid, and LPS were present. Less than $1 \%$ of the total RNA was recovered in this fraction. Pre sumably, this fraction contained fragments of the cell envelope.

The second fraction, fraction 11 , consisted of RNA and protein in a ratio of 1.9 , indicating that this fraction contained purified ribosomes. No LPS and only traces of phospholipid could be detected in this fraction. Sucrose density gradient centrifugation confirmed the presence of ribosomes in the crude ribosomal preparation and in fraction II. Moreover, activity of succinate dehydrogenase and p-lactate dehydrogenase was found in the crude ribosomal preparalion and in fraction I, but not in fraction II (data not. shown).

Fractions I and II induced protection in mice 
thin by the purfied rbosomal vaccine is alsom nal due to contaminating 1 . Wh. "The ressons that the protection by the unified ribosomal preparation of lieberman et al. (12) is RNA independent

it and that the protection of our purified ribosomat vaccine is RNA dependent could be because different $P$ aeruginosa strains were used, the purification procedures were not the same, Lie berman et al. used a higher challenge dose, or 5. all of these. It is unlikely that the conflicting in observations could be due to the mouse strains id used, since we also obtained protection with fraction II in C57BL/10 mice (data not shown).

\section{ACKNOWLEDGMENTS}

We are indebted to J. M. N. Willers iDepartment of Im munvilogy, Laboratory of Microbiology. State University of Wtrecht. The Netherlands) for his invaluable adwice and gtinullating atggeations. We thank Frans L. Sussen (Department of Pathology and Immunology. State University of Limburg. The Netherlands) for his helpful discussions during the prep" aration of this manuscript.

\section{LITERATURE CITED}

1. Alexander, J., W, and M. W. Fisher.19\%4. Immonization aggingt. Psedomonas in infection after therrial injury. J. Infeet. Dis. $130($ Supply:S152-S158.

of

be

he

ol.

m-

to

ac-

by

2. Andron, L. A., and H. T. Elgelsbach. 1975. Biochemical and immunological properties of ribonucleic acid-rich extracts from Francisella tharensis. Infect Immun. $12: 137-142$

3. Angerman, C. $\mathbb{R}$, and T. K. Eisenstein. 1978. Comparative effreacy and toxicity of ribosomal waccine, ace tonekilled cells, lipopolysaccharide, and a live cell vachime prepared from Salmonella typhimuriazm. Infect. Immun. 19:575-582.

4. Bradley, . V. 1968. Distribution free statistical testis, $p$. 216-22f. Prentice-Hall Inc. Englewond Cliffis, N.J.

5. Burton, K. 1956. A study of the conditions and methat rism of the diphenylamian reartion for the colorinnetric

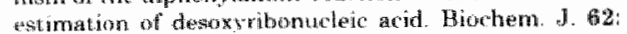
$.915-332$.

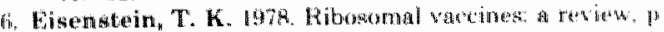
$211-222$ In A. Volter and H. Friedman led X. Nen lrends and dewelopments un vareines. MTL" Press Limited, St lieonard Gate.

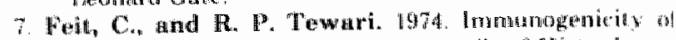

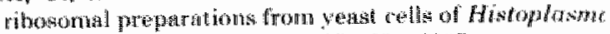

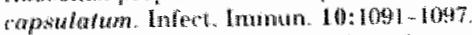

4. Hartree, E. F 1972. Determination of protein: for modit

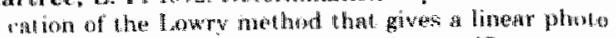
metio response. Anal. Biochem $48: 42: 2-42 \pi$.

9. Herbert, D. P. H. Phipps, and R. E. Strange. 1971 cheminal analysis of microbial cells, p $308-328 . \mathrm{m}$. R. Nonis and D. W. Ribbons (ed.), Methords in micti

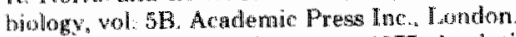

10. Horton, $D_{\text {. and }} G$. Rodemeyer. 1977. Analytical chas acterization of lipopolysaceharide antigens from seve straitus of Pseudomonas aeruginosa. Carbohydr. Re! $55: 35-47$,

11 Jensen, A, B. Gregory, J. Naylor, and P. Actor. 197; lisolation of protective somatic antigen from Vibri thalerae Cogawal ribesomal preparations. Infect. In msun $6: 156-161$.

12. Lieberman, M. M. 1978, Psetomonas ritossomal wia

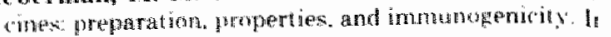

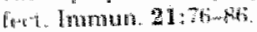

13 livberman" M. M., D. C. MeKissock, and G. I 


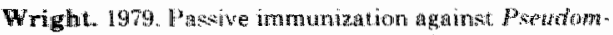
onts with a ribosomal vacone induced immune serum and immunoglobulin fractions. Infect. Immur. 23:509. 521

14. Mennington, J. E. 1974. Preliminary investigutions of Preudomonas acrumos vacoine in patients whith levkemia and cyatic frimosis. J. Infect. Dis. 130(Suppl.): $\$ 159-9162$

15. Pier, C. B., H. F. Sidberry, and J. C. Sadoff, 1978 Protective immunity induced in mice by immumation whth high-molecular-weight polysaccharide from Paeudomonas aeruginowe. Infect. Immun. 22:919-925.

14. Reed, C.F, S. N. Swisher, G. V. Marinett, and F. G. Edem. 1960. Sudius of the lipidis of the etythroyte 1 . Quantative analysis of the lipids of normal buman red blood cells. I. Tab. Cllim. Med .56:281-28\%

17. Keed, L. J. and H. Muench. 1938. A simple method for estimating fifty per cent endpoints. Am. J. Hyg. 27:493497 .

18. Smith. R. Ls, J.A. Wysocki, J. N. Braun, S. d. de Courcy, jx, W. S. Blakemore, and S. Mudd. 1973 Efficacy of ribosomal preparations from Pseudomonas asmginosa to protect against intravenous $P$ sewdomo- nos chalenge in nice. FES \&. Reticulowdothel. Sof.

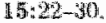

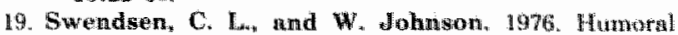

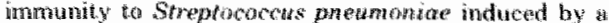
pheumococes ribosomal proten fracion. linfect lmamen. $14: 345-354$

20. Weissbach, A., Hand Hurwitz. 1950. The formation of

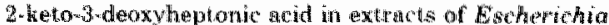
coll B. 1. Idencification. B. Biol Cherta. 234:705-709.

21. Willors, M. N., N. Bloksma, C. van der Meser, H.

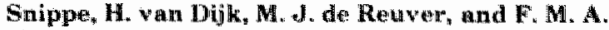
Hof huis. 1979. Rezulation of the inmune response by "rackophages. Antonie van Leawenhoels .]. Miorobiol. Serol. $45: 41-48$.

22. Youmans, A. S., and G. P. Youmban, $\$ 965$. Hramuno. grenic activity of a ribosomal fractoon oblained from Mycobacterium tuberculosis. J. Bateriol 89:12911298.

23. Youmane, A. S., and C. P. Youmanti. 1966. Effect of brypin and ribonuderse on the immunowenic activity of ribosomes and ribonuclac acid isolated from Myco.

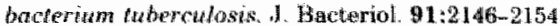




\title{
Evidence for the Presence of Lipopolysaccharide in a Ribonuclease-Sensitive Ribosomal Vaccine of Pseudomonas aeruginosa
}

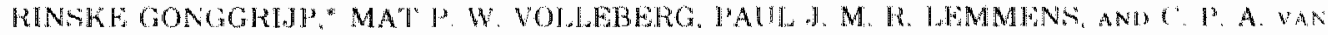 \\ BONEN

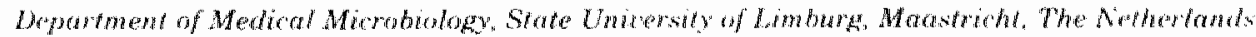

\begin{abstract}
To obtain information about the nature of the immunogens in the ribosimal vaccine (fraction $I 1)$ of Pseudomonas aeruginosa, we studied the specificity of rabbit antibodies to fraction II. Crossed immunoelectrophoresis demonstrated the presence of antibodies which precipitated with ribosomal antigens, but not with lipopolysaccharide (LPS). By means of an enzwme-linked immunosombent assav, antibodies to L.PS were detected in antibodies to fraction $\mathbb{I}$. Antibodies to fraction II could protect mice against a lethal challenge with $P$. aeruginosa. Absorption experiments demonstrated that the protective ability of antibodies 10 fraction II was due to antibodies to cell envelope antigens, whereas antibolies to ribusomal antigens did not contribute to the protection. Antibodies to LPS could be deterted in mice I week after a single vaccination with fraction II. II was concluded that the protective activity of fraction II was due, at least in part, to the presence of $D_{0} P S$ in the ribosomal vaccine. Treatment of fration II with ribonuclease decreased the profective activity of the ribosomal vaccine. Addition of synthetic polyadenylic ax id polyuridylic act restomed the protective activity on ribonuclease-treated fraction $1 \mathrm{I}$, indicating 1 hat RNA in the ribosomal vat cone might act as an adjuvant or a carrier in the presentation of the contuminating celll envelope antigens. The protective activity and the toxicity of fraction II were compared with the protective activity and the toxicity of fraction 1 , which contained cell envelope components, including $\mathbb{D}$ PS, and of purified LPS. "The results indicated that protection by the ribosomal vaccine was associated with at slightly higher toxicity than was protection by faction 1 , whereas purified l. was the most toxic vaccine.
\end{abstract}

Since Youmans and Youmans showed the profective activity of ribosome-rich preparations from Mycobacterium tuberwlosis (24), effective ribosomal vaccines have been prepared from various micoorganisms (6). However, consideratbe controversy exists in literature concerning the immunogenic principle of these vaccines. Investigators working on rihosomal vaceines of salmonellae have variously concluded that the at live molety is ribonucleic acid (RNA) (21), protein isolated from the ribosomal fraction (14). $O$ antigens $(5)$, or cell surface proteins contaminating the ribosomal preparation (15). Recently. several authors concluded that the protective activity of the ribosomal vaccines was due to contaminating cell surface components; no evidence was presented showing that the ribosomes themselves contributed to the protection $(7,12$, 15).

In a previous report, the isolation of a purified ribosomal vaccine (fraction $\mathbb{I}$ ) and a fraction containing cell envelope components (fraction l) from Psedudomonas aeruginosa was described
(8). Fraction I contained protein and lipopolysacharide (LPSi and less than 4\% RNA. Howction II contained RNA and profein in a rat io of 1.94. "The most remarkable property of fraction II was its sensitivity to ribonuclease: (RNase), indicating that RNA was indisysensable for the protective activity of this ribosomal wactine. Treatment of fraction II with pronase and trypsin did not abolish the protection. "Whe funetion of liNA in this ribosomal vaceine was not darified. RNA might act as a carrier of an adjuvant for traces of an unidentified profease-resistant component in the ribosomal vaccine. Alterna. tively. RNA might be the protective component. The former hypothesis was favored by the finding that the protection by fraction II was sero. type specific. The serotype-specific 0 antigens of $P$. aeruginosa are part of the cell wall component LPS. Although no L.PS could he deterled in fraction II by the determation of $2-k e t(0-3-$ deoxvoctonate (KDO), the prestence of tratses of L.PS could not be excluded. "The results pitesented in this paper demonstrated hat, although 
the ribosmall vacome was sensitive to lRW ast treatment, it induced antibodiew LPS. "Wherefore, the hypothesis that RNA in the riboswmal vaceine might tunction as a carrier or an adjuvant in the presentation of the contaminating cell envelope antigens is supported. The protective capacily and the toxicity of fraction $\mathbb{I}$, fraction II, and LPS have been compared.

\section{MATERLALS AND METHODS}

Bacteria. $P$. deruginosa serotype 3 (strain RTV 76 . 5321) (8) was used throughout this atudy for the preparation of the vaccines and as the challenging orgaw nismin.

Animals. Outbred male and female Cpb SE Swiss mice (body wight, 18 to $20 \mathrm{~g}$ ) were purchased from TNO, Central Institute for the Breeding of Laboratory Animals, Zeist. The Netherlands. Malle or female crossed Flemish giant rabits, weighing 3 to $4 \mathrm{~kg}$ each, were used.

Vaccines. Fractions I and II were obtained from a erude ribosomal preparation by molecular sieve chromatography on Sepharose Cl-2B as described previously (8). Four batches of fraction I and four batches of fraction II were pooled. The determination of RNA and protein and the estimation of LPS by the determination of KDO were performed as described previously (8). Fraction I contained $34 \mu \mathrm{g}$ of RNA $285 \mu \mathrm{g}$ of protein, and $98 \mu \mathrm{g}$ of LPS per mg (dry weight). No LPS was detected in fraction II, which implies that fraction Il contained less than $0.8 \mu \mathrm{g}$ of LPS per mg ldry weight).

LPS was extracted from aqueous suspensions of reeze-dried bacteria with $45^{\circ}$ (wt/wol) phenol at $70^{\circ} \mathrm{C}$ 193. The combined aqueous phases were dialyzed against water and subsequently centrifuged for $4 \mathrm{~h}$ at $100,000 \times g$ at $4^{\circ} \mathrm{C}$. The sediment was suspended in sterile water and freeze-rlied. The dry material was suspended in sterile water and incubated at $37^{\circ} \mathrm{C}$ with deoxyribonuclease $(0.5 \mathrm{mg} / \mathrm{m}$; $\mathrm{E}$. Merck $\mathrm{AG}$. Darmstadt, West Gormany) for $30 \mathrm{~min}$.

Pancitatic RNage $(0.5 \mathrm{mg} / \mathrm{mll})$ and $T$, RNage $(200$ U/mi) (Boehringer Mannheün Corp. Mannheim, Woat Germany) were added, and incubation was con. tinued for $60 \mathrm{~min}$. Subsequently, pronase $\mathrm{E}(0.5 \mathrm{mg} /$ mli Marck) was added, and incubation was continued lot 1. h. The mixture was centrifuged for 4 hat 100,000 $x$ \& at $4^{\circ} \mathrm{C}$, and the suspended pellet was freze-dried. Treatment with RNase and promage $\mathbb{B}$ was repeated. until the amounts of RNA and protein in the preparation were tuced to 2.4 and $8.4 \%$, respectively. $B y$ the determination of $\mathrm{KOO}$, the final preparation was astimated to contain $1,100 \mu \mathrm{g}$ of I PS per mg (dry wightol.

Rabbit antibodies against fraction I (fr. I-Ab) and fraction II (fr. I-Ab). All rabbits were bled from the ear vein before immunization to abtain preimmune sera. Rabbits were injected intracutaneously with 3 me of fraction 1 dialyzed overnight against distilled water or with 20 ng of fraction II. The fractions were incorporated in 1 volume of Arlacel 11.5 and $2 \mathrm{ml}$. respectively) containing $200 \mu \mathrm{g}$ of muramyl dipeptide (Inst tut Pasteur Production, Paris, France). Booster injections without adjuwant were given at 4 and 5

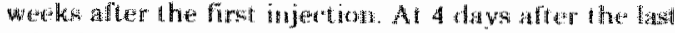
infection, the rabbis were bled by ardiac puncture. Groups of three to four rabbits were used for each fraction, and the immune sera of the individual rabbits in each group were pooled.

The sera were cooled in ice and diluted with 1 volume of phosphate-buffered physiological salume (PBS). Two volumes of saturated $\left(\mathrm{NH}_{4} / \mathrm{SO}_{4}\right.$ solution $(\mathrm{pH} 7.4 \mathrm{l}$ were added slowly. The mixture was stirred for $30 \mathrm{~min}$ at $0^{\circ} \mathrm{C}$ and centrifuged for $10 \mathrm{~min}$ at 1,200 $\times \mathrm{g}$. The sediment was suspended in the original volume of PBS. Subsequently, nine-tenths of this volume of saturated $\left(\mathrm{NH}_{4}\right) \mathrm{SO}_{3}$, solution was added. The mixture vas stirred for 30 min $\mathrm{at}^{\circ} \mathrm{C}$ and centrifuged and the sediment was suspended in one-third of the original volume of PBS. The antibody preparation was centrifuged for $15 \mathrm{~min}$ at $1.500 \times \mathrm{g}$ at $4^{\circ} \mathrm{C}$ to remove aggregated matterial. The supernatent was dialyzed against PBS for $48 \mathrm{~h}$. The antibody preparation was filtered through a $0.2-\mu \mathrm{m}$ Sartorius filter and stored in small portions at $-20^{\circ} \mathrm{C}$.

Decomplementation was performed by heating the antibody preparation at $56^{\circ} \mathrm{C}$ for $30 \mathrm{~min}^{-\beta}$-Mercaptoethanol treatment of decomplemented antibody preparations was performed as described by Lieberman et al. (11).

Antisera of mice. Sera were obtained from mice by orbital puncture at 6 days after waccination. Sera from five mice were pooled for the determination of specific antibodies.

Absorption of rabbit antibodies. Absorption of fr. $\mathbb{L}$-Ab and fr. II-Ab before use in crossed immunoelectrophoresis was performed by incubation for 30 min at $37^{\circ} \mathrm{C}$ with 1 volume of fraction $I(10 \mathrm{mg} / \mathrm{ml})$, fraction III (10 $\mathrm{mg} / \mathrm{ml})$, LPS (1 $\mathrm{mg} / \mathrm{mll}$, or living $P$. aeruginosa bacteria $\left(2.5 \times 10^{3} / \mathrm{ml}\right)$. Precipitates were removed by centrifugation. After absorption with liv. ing bacteria, the antibody preparations were filtered through a $0.2-\mu \mathrm{m}$ Sartorius filter.

Absorption of the antibody preparations before 1 use in the enzyme-linked immunosorbent assay (ELISA) or in passive protection experiments was performed with a one eighth dilution of decomplemented fr. I-Ab and with undiluted decomplemented fr. II-Ab. One volume of antibody preparation was incubated with 1 volume of fraction $1110 \mathrm{mg} / \mathrm{ml})$, LPS $(1,2$, or $4 \mathrm{mg} /$ ml). or killed bacteria $\left(2.5 \times 10^{\text {th }} / \mathrm{ml}\right)$. Bacteria were killed by incubating 19 volumes of bacteria with 1 volume of $35 \%$ (wt/wt) formaldehyde for $30 \mathrm{~min}$ at room temperature. The bacteria were washed twice with PBS before use.

Crossed immuncelectrophoresis. Crossed im. munoalectrophoresis was carried out on glass plates (10) by $10 \mathrm{~cm}$ ) with a $1.1 \mathrm{~g}$ agarose gel (Merck) in 0.1 M barbital buffer (pH 8.6) containing $0.01 \%$ Merthiol. ate. The thickness of the gel was 1 min. The volume of the sample was $10 \mu$. "The first-dimension electrophoresis was carried out at $10 \mathrm{~V} / \mathrm{cm}$ for $1 \mathrm{~h}$ at $12^{\circ} \mathrm{C}$. The second-dimension electrophoresis was carried out at $2.5 \mathrm{~V} / \mathrm{cm}$ for $16 \mathrm{~h}$ at $12^{\circ} \mathrm{C}$ in an agarose gel contain. ing $0.1 \mathrm{mll}$ of the antibody preparation per $\mathrm{ml}$ of gel. Each plate was divided in two parts, so that two samples could be run per plate. After the second. dimension electrophoresis, the gel was washed twice for $15 \mathrm{~h}$ in $0.9 \% \mathrm{NaCl}$ and subsequently for $1 \mathrm{~h}$ in 
distilled water. After drying ithe plates were stained with $0.5 \%$ (wol/ wol) Coomassie brillant blue G (Merck) in ethano-glacial acetic acid-water (45:10:45) for 15 min. The excess of dye was removed by repeated washings in dye-frew solvent.

FLISA. ELISA for the detection of rabbit antibod. ies to LPS was performed as described by Vos et al. (22) whith slight modifications. Coating of the micron plates was performed orernght with a final concentra. ifon of $2.5 \mathrm{mg}$ of $L P S$ per $\mathrm{ml}$ at room temperature. The travs were incubated with serum dilutions for $1 \mathrm{~h}$ at $37^{\circ} \mathrm{C}$. After washing the trays were incubated with peroxidase-labeled goat ant $\mathrm{r}$ - abbit immunaglobulin $\mathrm{C}$ Nordic Immunological Laboratories, Thlburg, The Netherlands) in a dilution of 1.500 for $1.5 \mathrm{~h}$ at $37^{\circ} \mathrm{C}$. The substrate 5-aminosalicylic acid was purified by recrystallization after filtration wer activated charcoal the reaction was evaluated visually and expressed as $\log _{\text {in }}$ of the highest dilution giving positive reaction. The specificity of FLISA was controlled by the use of Escherichia coli L.PS for the coating of the microplates.

Mouse antibodies to LPS were determined in the same way with peroxidase-labeled sheep anti-mouse immunoglobulin G (Institut Pasteur Production) in a dilution of 1:500.

Passive protection of mice with rabbit antibodies. Mice were injected intraperitoneally with 0.2 mi of serial dilutions of rabbit antibodies in PBS. After $3 \mathrm{~h}$, a lethal challenge with $P$. aeruginosa was given intraperitoneally.

Vaccination and challenge of mice. Mice were vaccinated and challenged as described previously (8) with the following modifications. Fraction II $(0.1 \mathrm{ml})$ was mixed with an equall volume of adjuvant. i.e., a sonicated suspension containing $1.5 \mathrm{mg}$ of dimethyl dioctadecyl ammonium bromide (DVI) per $\mathrm{ml}$ of PBS; vaccinations were given intraperitoneally. The challenge dose contained $3.550 \%$ lethal doses of $P$. aeruginosa. Deaths, which occurred principally within 2 days after challenge, were recorded 7 days after challenge.

PD $_{\text {s. }}$. Vaccine doses that protected $50 \%$ of the mice against a challenge of $3.550 \%$ lethal doses $\left(\mathrm{PD}_{\mathrm{ra}}\right)$ were determined graphically as described by Nowotony (1).

Treatment of fraction II with RNase and addition of poly $(\mathbf{A}-\mathrm{U})$. Before enzymatic treatment, frection II was dialyzed against $0.005 \mathrm{M}$ ethylenediaminetetrancetic acid $(\mathrm{pH} 7.2)$ overnight at $4^{10} \mathrm{C}$ and then dialyzed against distilled water for $1 \mathrm{~h}$. RNase A. ENZYGEL (20 mg; Bochringer Mannheim) was added to $2 \mathrm{mg}$ of fraction. Il in a total volume of 4.5 mol. The mixture was incubated on a roller mixer for 4 hat $37^{\circ} \mathrm{C}$. RNase $A$, ENZYGEL was removed from the mixture by centrifugation at $100 \times g$ for $10 \mathrm{~min}$ and washed several times with a lotal volume of 15.5 ml of water. The wash fluid was added to RNasetreated fraction III. RNase-treated fraction II was subsequently filtered through a $0.2-1 \mathrm{~m}$ Sartorius filter. Polyadenylic acid-polyuridylic acid [poly (A. U): Boehringer Mannheim] wass added to RNase-treated fraction 11 . this preparation was miked with DDA. Dialyzed fraction II which was not treated with INase A. ENTYGEL was used as a comtrol.
Toxicity of vaceities to lead acetate-sensitized mice. Vaccines were dialyzed aganst distilled waten at $4 \mathrm{C}$ overnight. To dilwhons of the wecine lead acetate was added to a final concentration of $20 \mathrm{mu}$; ml. A volume of $0.1 \mathrm{mbl}$ of the vaccine in lead acetate was injected intravenously in the tril wein. Weaths were recorded 7 days after injection. To inject. $10 \mathrm{mg}$ of fraction II per mouse, fraction II was concentrated by treaze-drying after dialysis. Lead acetate $(0.1 \mathrm{mbl})$ was injected 15 min before the injection of $0.1 \mathrm{mil}$ of fraction II $(100 \mathrm{nng} / \mathrm{ml})$

TD $D_{\text {sio. }}$ Vaccine doses that were lethal to sot of lead acetatemsensitized mice (TD graphically as described by Nowotony (17).

Statistical evaluation. Significance lavals for protection were determined by the Fisher exact test, as described by Bradley (4).

\section{RESULTS}

Crossed immunoeleetrophoresis. Crossed immunoelectrophoresis of fractions I and II against $\mathrm{fr}$. I-Ab and $\mathrm{fr}$. II-Ab, respectively, resulted in different precipitation patterns (Fig. $1 \mathrm{~A}$ and B). Precipitation patterns of fraction I against fr. II-Ab and of fraction II against fr. I$\mathrm{Ab}$ demonstrated the presence of cross-reacting material in fractions $\mathrm{I}$ and $\mathrm{II}$ (Fig. $1 \mathrm{C}$ and $\mathrm{D})$. fr. I-Ab contained antibodies precipitating with LPS (Fig. 1E). No precipitation was observed when LPS was run against fr. II-Ab (Fig. 1F). Absorption of fr. I-Ab with fraction I $(5 \mathrm{mg} / \mathrm{ml})$ resulted in the complete disappearance of the precipitation pattern of fraction I against $a b$. sorbed fr. I-Ab (Fig. 2A). After absorption of fr. II-A b with fraction II $(5 \mathrm{mg} / \mathrm{ml})$, only one weak precipitation line was visible when fraction II was run against absorbed fr. II.Ab (Fig. 2B). Part of the precipitation pattern of fraction I against, fr. I-Ab disappeared when fr. I-Ab were absorbed with LPS or with whole cells of $P$. aeruginosa (Fig. $2 \mathrm{C}$ and E). No loss of precipitation lines from the precipitation pattern of fraction II against fr. II-Ab was observed when fr. II-Ab were absorbed with LPS or with bacterial cells (Fig. 2D and F).

Detection of antibodies to LPS by EILISA. By means of ELISA, antibodies to LPS could be detected in fr. 1-A.b and in fr. II-Ab (Table 1). The concentration of antibodies to LPS in fr. I. Ab was 8 to 16 times higher than that in $\mathrm{fr}$. II$A b$. Absorption of fr. I-Ab and fr. II-Ab with increasing concentrations of LPS resulted in a gradual decrease in the titer of antibodies against LPS. Also, absorption of $\mathrm{fr}$. I-Ab and $\mathrm{fr}$. II-Ab with whole cells of $P$. aeruginosa reduced the titer of antibodies to LPS. Absorption of $\mathrm{fr}$. II-Ab with fraction II did not reduce the titer of antibodies to LPS.

Passive protection of mice with fr. I-Ab and fr. II-Ab. fr. I-Ab and fr. II-Ab protected 

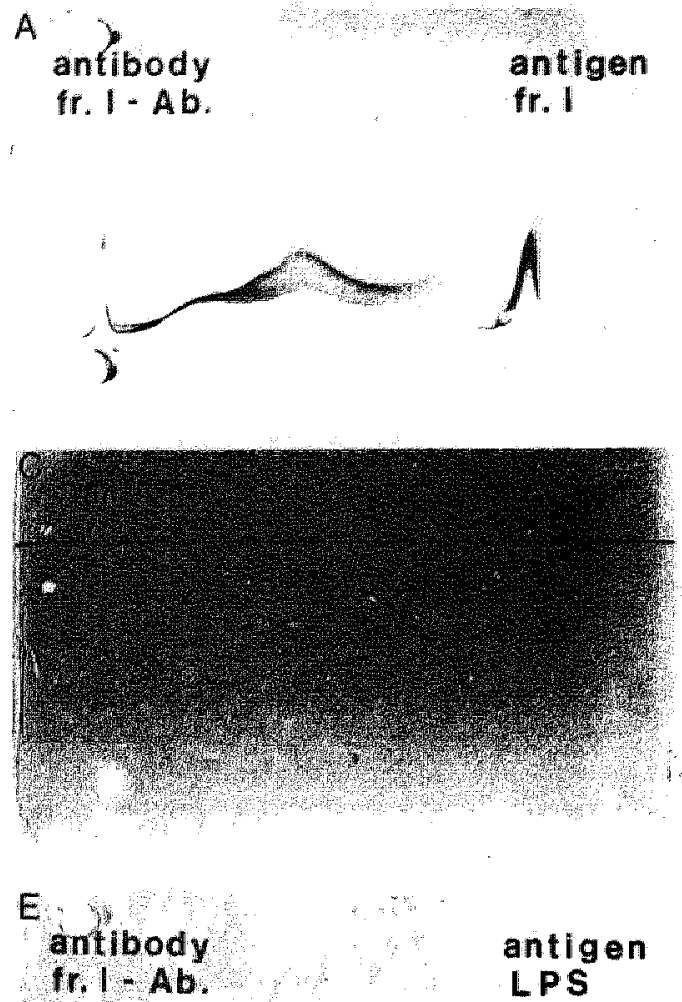

the

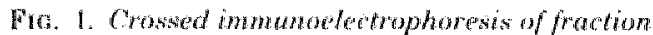

mice against a lethal challenge with $P$. aeruginosa (Table 2). To obtain similar percentages of survival, concentrations of $\mathrm{fr}$. II-Ab about 10fold higher than those of $\mathrm{I}$. I-Ab were required. Decomplementation of the antibody prepara. tions by heating for 30 min at $56^{\circ} \mathrm{C}$ reduced the protection by the 1:10 dilution of fr. II-Ab ( $P$ value with respect to the conesponding dilution of untreated $\mathrm{f}$. II-Ab was 0.03 . Treatment of decomplemented $\mathrm{Cr}$. I-Ab and fr. II-Ab with $\beta$. mercaptoethanol demonstrated that immunoglobulin $M$ antibodies did not contribute to the protection.

Passive protection experiments with absorbed decomplemented antibodies were performed to study the specificity of the protective antibodies in $\mathrm{fr}$. I-Ab and $\mathrm{fr}$. II-Ab. Preliminary experiments indicated that LPS was impracticable for absorbing the antibody preparations which had to be used in passive protection experiments. Part
B

\section{antibody}

fr. II- $A$ b.

antigen

fr. II
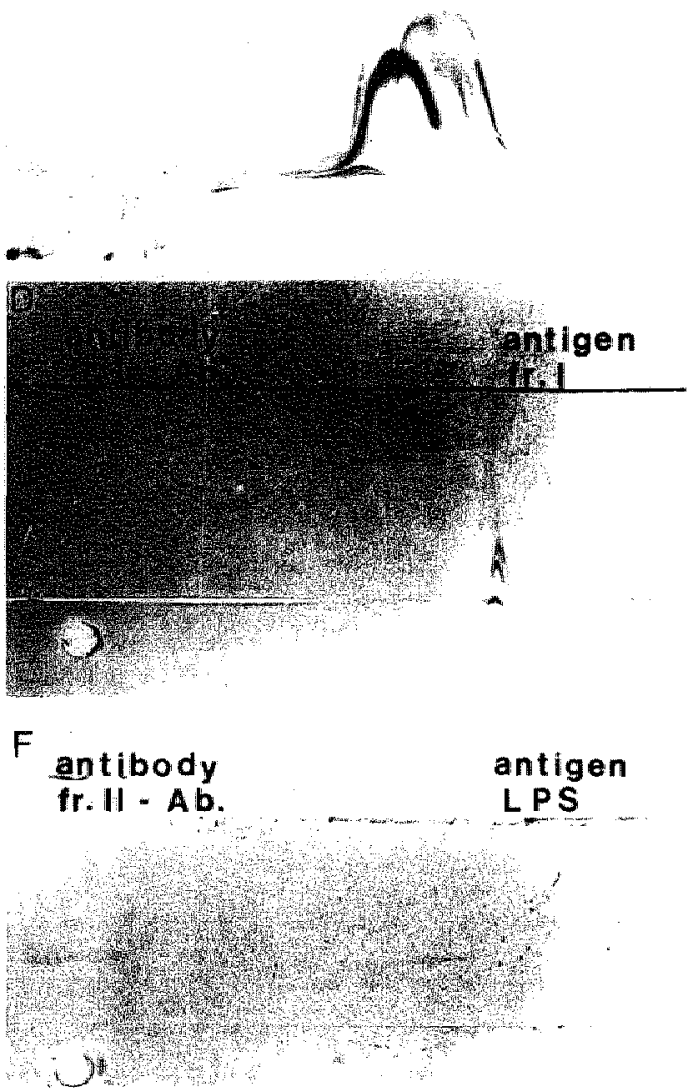

I. fraction II, and LPS against in: I-Ab and fr. II.Ab.

of the LPS remaned in the antibody preparation and influenced the outcome of the passive protection experiments due to its toxicity. Therefore, absorption of the antibodies was performed with whole cells of $P$. aeruginosa. The results demonstrated that protection by Fr. I-Ab and fr. II-Ab was due to antibodies against cell envelope components (Table 3). Absorption of fr. II-Ab with fraction II did not reduce the protection by fr. II-Ab.

Antibodies to LPS in mice induced by different doses of LPS, fraction I, and fraction II. The titers of antibodies to L.PS in sera of mice and the percentages of survival of mice that were vaccinated with graded doses of LPS, fraction I, and fraction II are shown in Table 4. By means of ELISA, antibodies to L.PS were detected at 6 days after a single vaccination with I.PS, fraction I, or fraction II. Increasing doses of vaccine were assuciated with increasing titers 
A
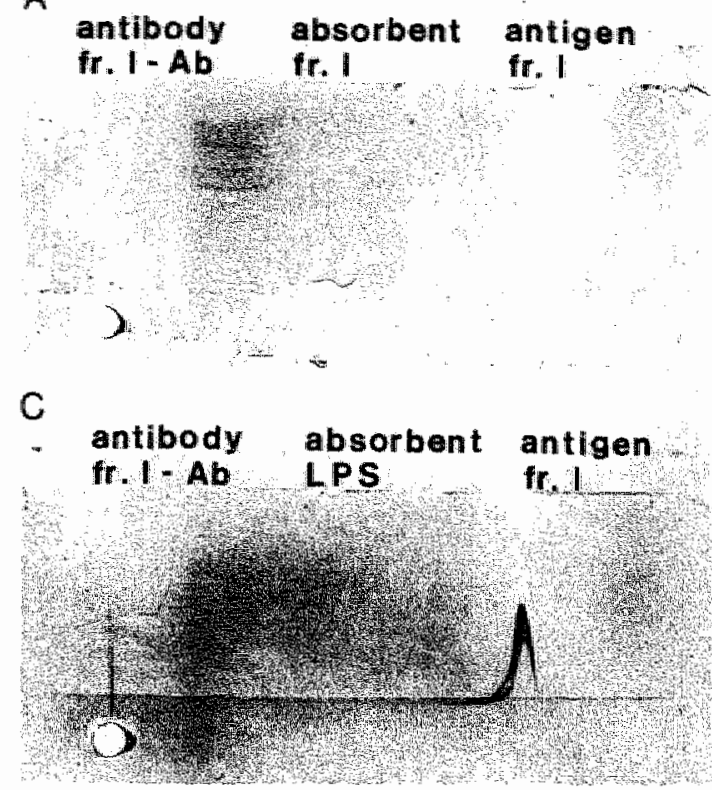

$E$

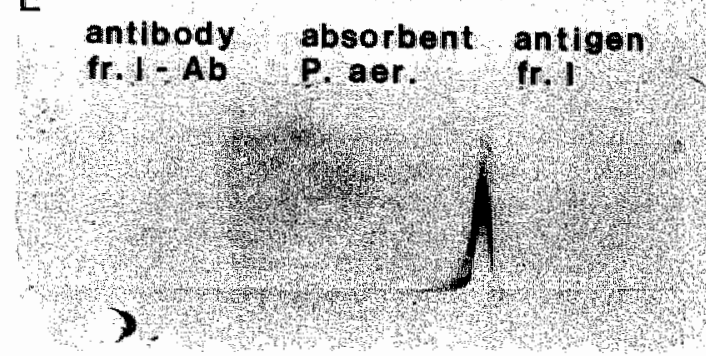

B
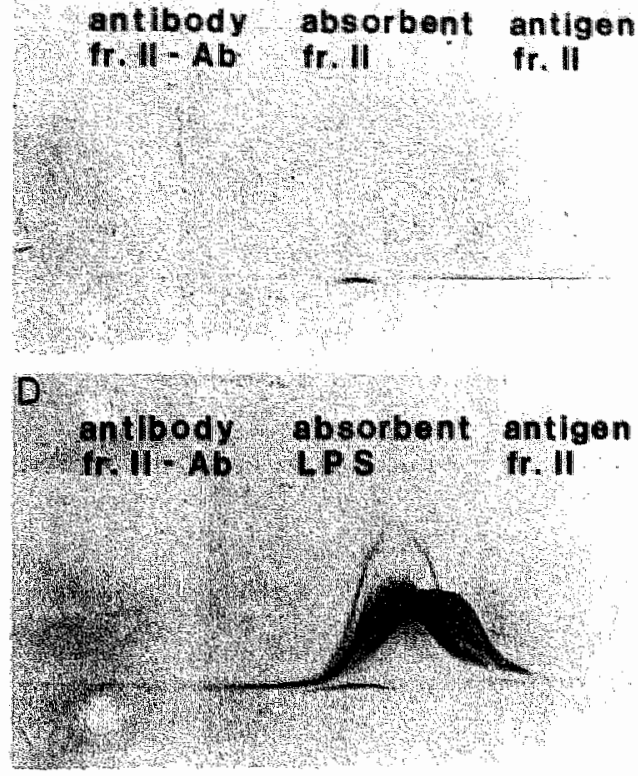

F

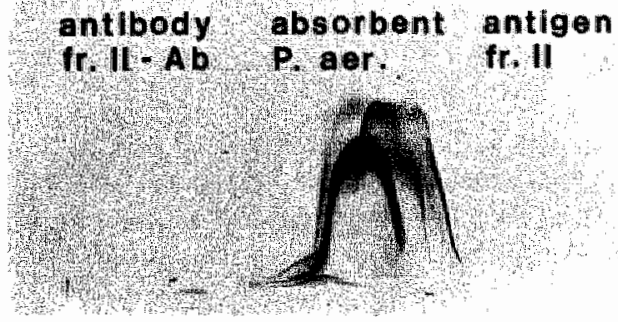

FIG. 2. Crossed immumoelectrophoresis of fractions I and II against fr. I.Ab and fr. II-Ab after absorption of the antibody preparations with different antigens. $P$. aer. $P$. aevuginosa cells.

of antibodies and increasing percentages of mouse survival.

When the percentages of survival were plotted as a function of the corresponding titers of amtibodies to LPS, it appeared that similar correlation existed between survival and titers of antibodies to LPS induced by fraction I or LPS (Fig. 3). The results suggested that protection by fraction II was associated with lower titers of antibodies to LPS than was protection by fraction I or LPS.

Since in fractions I and II the presence of LPS was demonstrated by the ability of the fractions to induce antibodies to LPS, it was of interest to determine whether the protective capacity of fraction I, fraction II, and LPS was correlated with the concentration of LPS in these vaccines. The $P D_{50}$ values of the vaccines were calculated from the results shown in Table 4. LPS was estimated by the determination of KDO. It ap- peared that the $\mathrm{PD}_{60}$ of the purified LPS vaccine contained 24 times more L.sS than did the PDst of fraction I (Table 5). Ass LPS could not be detected in fraction II by the determination of $\mathrm{KDO}_{\mathrm{s}}$ the amount of LPS in the PDin of fraction II could only be estimated to be less than $1.3 \mathrm{ng}$.

Restoration of the protective activity of RNase-treated fraction II by the addition of $\operatorname{poly}(A \cdot U)$. Incubation of fraction II with RNase A, ENZYGEL reduced the protective activity of this vaccine (Table 6). Different amounts of poly(A.U) were added to RNase. treated fraction II in an attempl to restore the protective activity of this ribosomal vaccine. Addition of 50 or $300 \mu \mathrm{g}$ of poly(A.U) to RNasetreated fraction II increased the protective activ. ity significantly. Injection of $300 \mu \mathrm{g}$ of poly(A. U) alone also induced protection.

Toxicity of LPS, fraction I, and fraction II for lead acetate-sensitized mice. Selye et 


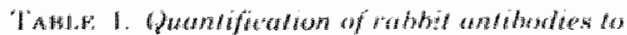

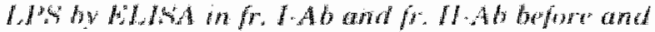

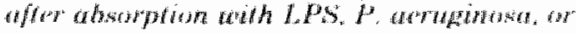
frotion II

\begin{tabular}{|c|c|c|}
\hline Antibualy perepot & 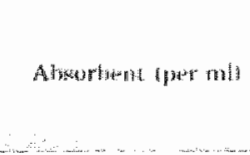 & 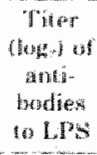 \\
\hline $\mathrm{fr}, \mathbb{1} \cdot \mathrm{Ab}$ & & 14 \\
\hline fr. $1-A^{i s}$ & $0.5 \mathrm{mg}$ of LIS & 8.5 \\
\hline fr. $1 . b^{\prime \prime}$ & $1.0 \mathrm{mig}$ of $\mathrm{L} / \mathrm{s}$ & 7 \\
\hline fr. $1-A^{6}$ & 20 man of $1 . \mathrm{P}^{3} \mathrm{~s}$ & 6 \\
\hline fr. $\mathrm{L}-\mathrm{Ab}^{\prime \prime}$ & $\begin{array}{l}1.25 \times 10^{31} H \\
\text { aeruginowa }\end{array}$ & 12 \\
\hline $\begin{array}{l}\text { Preimimune } \\
\text { antibodies }\end{array}$ & & 6.5 \\
\hline fit: II-AL & & 10.5 \\
\hline $\mathrm{fa} \cdot 11 \cdot \mathrm{Ab}$ & $0.5 \mathrm{mg}$ of $\mathrm{LPS}$ & 8 \\
\hline fr. $11-\mathrm{Ab}$ & $1.0 \mathrm{mg}$ of L.LS & $\pi$ \\
\hline$\| 1 \cdot 11 \cdot A l)$ & $2.0 \mathrm{mg}$ of Ll's & 6 \\
\hline Di: $11 . A b$ & $\begin{array}{l}1.25 \times 10^{113} P \\
\text { aeruginosi }\end{array}$ & 8.5 \\
\hline 1r. $11 \cdot \mathrm{Ab}$ & 5 meg of fraction II & 10 \\
\hline $\begin{array}{l}\text { Treinumune } \\
\text { antibodies }\end{array}$ & & 6 \\
\hline
\end{tabular}

fr. I-Ab wers diluted T:S betion absorption.

al. (18) demonstrated that intravenous injection of lead acetate increased the susceptibility of rats to the toxicity of LPS. Misfeldt and Johnson (13) applied this method to mice. Graded doses of LPS, fraction I, and fraction II were injected into lead acetate-sensitized mice to determine the toxicity of these vaccines. This toxicity is likely to be due to the LPS in the vaccine. The TD: concentration of LPS in the TD was determined by an independent method (Table 7 ). The concentration of LPS in the $T \mathrm{~T}_{\text {sol }}$ of fraction I and that in the TD' of the purified LPS preparation were about the same $(2.9$ and $2.1 \mathrm{\mu g}$, respectively). No LPS was detectable in fraction II, indicating that less than $1.6 \mu \mathrm{Mg}$ of L.PS is present in the TD, of fraction II.

Ratio of the PD to the TD $_{\text {sin }}$ of I.PS, fraction 1 , and fraction II. 'The ratio of the protective capacity of a vaccine to its toxicity has been used as a measure for its therapeutic quality (2). The lower the $\mathrm{PD}_{\text {sid }} / \mathrm{TD}_{\text {sid }}$ ration the less toxic is the vaccine dose needed to achieve a defined level of protection. The ratio of the $\mathrm{PD}_{\{x \mid}$ to the $\mathrm{TD}_{\text {sut }}$ for lead acetate-sensitized mice of LPS, fraction I, and fraction II is shown in Table 8 .

As judged by the $P D_{*} / T_{5 \times t}$ ratio, the therapentic quality of LPS is inferior to that of fractions I and II. The $\mathrm{PD}_{50} / \mathrm{TD}_{50}$ ratio of fraction II is somewhat higher than that of fraction I.

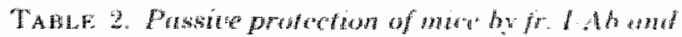
fr. II Ah

\begin{tabular}{|c|c|c|c|}
\hline \multirow[b]{2}{*}{ Anthody prepn } & \multicolumn{3}{|c|}{ 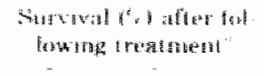 } \\
\hline & Nomet: & 56 & " \\
\hline $\begin{array}{l}\text { fr. } 1-A b^{*} \text { at dilution of: } \\
1: 20 \\
1: 50 \\
1: 100\end{array}$ & $\begin{array}{l}75 \\
160 \\
40\end{array}$ & $\begin{array}{l}85 \\
53 \\
50\end{array}$ & $\begin{array}{l}7+5 \\
60 \\
15\end{array}$ \\
\hline $\begin{array}{l}\text { Premmune antibodies } \\
\text { (1:20 dilution) }\end{array}$ & 10 & 5 & $\mathrm{ND}^{\prime}$ \\
\hline $\mathrm{PBS}$ & 0 & & \\
\hline $\begin{array}{l}\text { Ir. } 11-A b \text { at dilution of: } \\
1: 2 \\
1: 5 \\
1: 10\end{array}$ & $\begin{array}{l}83 \\
80 \\
60\end{array}$ & $\begin{array}{l}8: 3 \\
60 \\
3 ; 3\end{array}$ & $\begin{array}{l}509 \\
5 \times 5 \\
259\end{array}$ \\
\hline $\begin{array}{l}\text { Preammune antibodies } \\
\text { (1:2 dilution) }\end{array}$ & 20 & 17 & $\mathrm{NJI}^{\prime \prime}$ \\
\hline PBs & 7 & & \\
\hline
\end{tabular}

"fr. I-Ab and fr. II-Ab were applied without I reatment and after heating for $30 \mathrm{~min}$ in $56^{\circ} \mathrm{C}$ or after heating and treatment with $\beta$-mercaptuethano: $(/ \beta$ Miri).

"Groups of 20 mice were injected intraperitionerally" will $0.2 \mathrm{ml}$ of different dillutions of $\mathrm{fr}$. I-Ah and chai. lenged 3 h later with athal dose of $P$ aeruginost.

- Croups of 30 mice were injected intraperitoneally with $0.2 \mathrm{ml}$ of different dilutions of $\mathrm{f}$. $11-\mathrm{Ab}$ and challenged $3 \mathrm{~h}$ later with a lethal dose of $P$ aeruginosa. In the case of injection with $\mathrm{fr}$. II-Ab which were hented at $56^{\circ} \mathrm{C}$ and treated with $\beta-\mathrm{MF}^{\circ}$, only 20 waice per group were used.

"ND" Not determined.

\section{DISCUSSION}

Conflicting results have been reported regard. ing the nature of the inmunogen(s) in ribosomal vaccines. Recently, several authors concluded that the protection induced by their ribosomal vaccine was due to contaminating cell envelope components $(7,15)$; no evidence was found for $x$ function of the ribosomes in these vaccines. In contrast, a purified ribosomal vaccine (fraction II.) of $P$. aeruginosa, of which the protective activity was destroyed by treatment of the vaccine with RNase, thas been described (8). Since the protective activity of this vaccine was dependent on the presence of intact RNA, RNA may have been the immunogen in the ribosomal vaccine. Alternatively, RNA could have acted as a carrier or an adjuvant for traces of contaminating cell surface antigens. No cell envelope components, in particular, no ISPS, were detected in fraction II by means of chemical anal- 


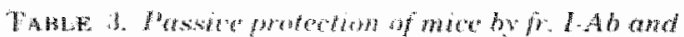

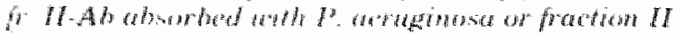

\begin{tabular}{|c|c|c|c|c|}
\hline \multirow{2}{*}{\multicolumn{2}{|c|}{ 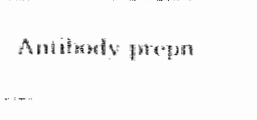 }} & \multicolumn{3}{|c|}{ 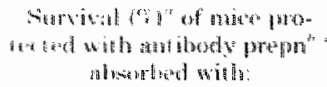 } \\
\hline & & & & $\ldots \ldots$ \\
\hline 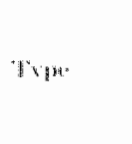 & Dolation & MBS & 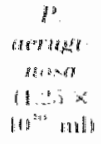 & 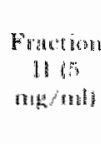 \\
\hline$\therefore A B$ & 1.36 & 45 & 15. & \\
\hline $1 . A$ & 1.50 & sis & $100^{4}$ & \\
\hline 115 & & $n$ & & \\
\hline$\| . M-A h$ & $1: 2$ & 64 & $\mathrm{rr}^{i}$ & 100 \\
\hline$\left\|^{2},\right\| I-A$ & 1.5 & 47 & $b y^{y i}$ & 55 \\
\hline 164 & & ) & & \\
\hline
\end{tabular}

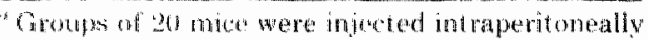

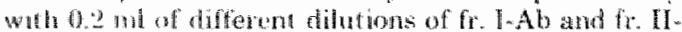
Ab and thallomged if h later with a lethal dose of $P$.

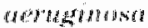

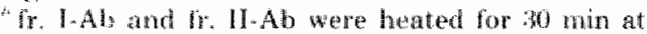

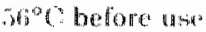

- I-Ab were dituted $1: 8$ before absorption.

" $p$ value is <ndol with respect to corresponding ditutions of the antibody preparations that were not in worbert

Ysis (8). In this paper, an analysis of antisera to fraction II was presented which demonstrated the presence of I.PS in the ribosomal vaccine.

Crossed immunoelectophoresis with fr. II-Ab demonstrated the presence of many different antigens in the ribosomal fraction. Some ribosomal antigens cross-reacted with antibodies to fraction 1 , fraction which contained cell envelope components. Antibodies to LIS could not be defected in fr. II-Ab by crossed immunotectrophoresis. However, antibodies to Id's ware dekeded in fr. II-Ab by ELISA. When fr. II-Ab were absorbed with fraction II, the antibodies which precipitated with the ribosomal antigens in crossed immunoelectrophoresis disappeared (Fig. 2B). In contrast, the titer of antibodies to LPS in fr. II-Ab was not reduced by this treatment (Table 1). Thus, LPS was present in the ribosomal vaccine. but the amount of LPS in fraction 11 was not sufficient to reduce the titer of antibodies to LPS.

Mice could be protected by fr. I-Ab and fr. II. Ab against a lethal challenge with $P$. aterugiNetsid. Absomption of fr. II-Ab with P. aeruginosa cells and with fraction If demonstrated that the protection by $\mathrm{f} r$. $|\mathrm{f}-\mathrm{A}| \mathrm{l}$ ) was due to antibodies to cell envelogre antigens. Antiborlies to ribosomal andigens did not contribute to the protection. Although it is likely that the protective activity of $\mathrm{fr}$. I-Ab and $\mathrm{fr}$. II-Ab is mainly dee to the

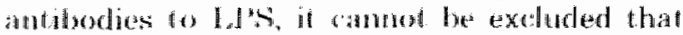

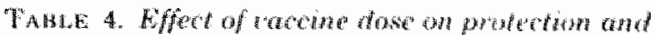

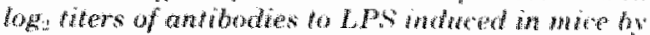
L.PS, fraction 1 , and fraction It

\begin{tabular}{|c|c|c|c|}
\hline Vateinte & 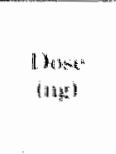 & $\begin{array}{c}\text { Suracial } \\
f^{x} ; 1\end{array}$ & 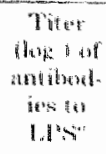 \\
\hline \multirow[t]{4}{*}{ L.11s } & 0.1 & $\|(27)^{k}$ & 28 \\
\hline & 1.0 & $90(-7)$ & $5 x$ \\
\hline & 100 & $11(20)$ & $1 i .8$ \\
\hline & 100.0 & $35(20)$ & $\mathrm{BS}$ \\
\hline \multirow[t]{5}{*}{ Fatrotion 1} & (1). 1 & $50(20)$ & 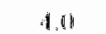 \\
\hline & 1.0 & $19(27)$ & 5.4 \\
\hline & {$[0.01$} & $41(27)$ & 76 \\
\hline & 1000 & $8, i(27)$ & 9.3 \\
\hline & $1,000,0$ & $100 ; \geq 0\}$ & 9.6 \\
\hline \multirow{4}{*}{$\begin{array}{l}\text { Fracion II, plus } \\
\text { DIDA }\end{array}$} & 10,0 & $0(2,27)$ & 1.2 \\
\hline & 100.0 & $4(27)$ & 2.5 \\
\hline & $1,000.0$ & $(8727)$ & 4.5 \\
\hline & $10,000,0$ & $90\{20\}$ & 7.8 \\
\hline Buffer & & $(1)(28)$ & 1.8 \\
\hline Buffer phus DDA & & $7(28)$ & 25 \\
\hline
\end{tabular}

"Determined by lid. LSA. Wach number represents the mean walue of determinations of three pouls of sera.

"Number of mice is given within parontheses.

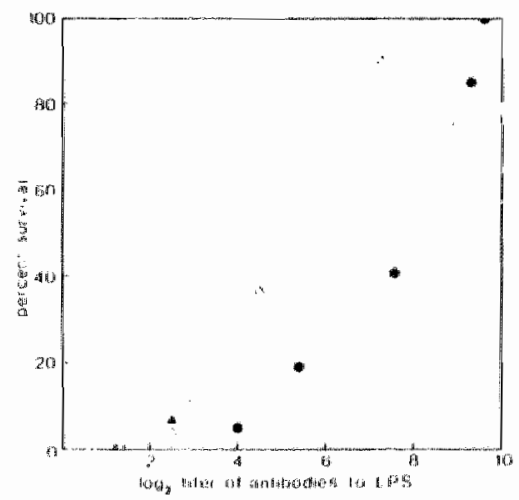

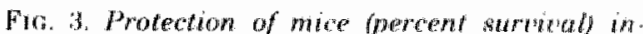
dinced by $L P S_{n}$ fraction 1 , and fraction II as a function of the corresponding loge titer of antibodies to $L P \mathrm{~S}$. Symbols: O LPS, fration I: $\triangle$, fraction II plus DDA: $\square$, buffer: $\triangle$, buffer plat DDA.

antibodies to other cell envelope components contributed to the protection. In this study, LPS was considered to be an indicator for the presence of cell envelope components.

In mice, fraction 1, fraction II, and LPS in duced antibodies to LPS at 6 days after a single vaccination. Increasing doses of vaccine wert 


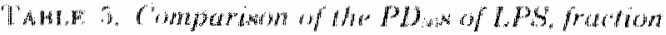

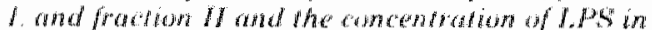
the $P D_{s i}$

\begin{tabular}{|c|c|c|}
\hline 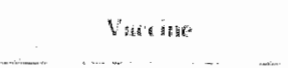 & $P D_{\alpha}$ ingrir & $\begin{array}{l}\text { Ins and } 1 \\
\text { in Ply: }\end{array}$ \\
\hline J.PS & 22 & 24 \\
\hline Fraction l & 10 & 1 \\
\hline Fration II phus DJ D & 1,600 & $<1.3$ \\
\hline
\end{tabular}

"T"the values are calculated roon the results shown in Tibles 4 .

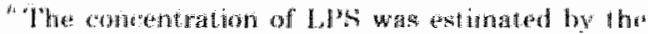
desterminat iont of KDO

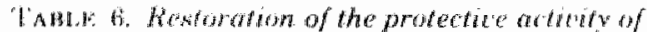
RNase trated fraction It by the addition of $\operatorname{pol}(\mathrm{A} \cdot(\mathrm{C})$

\begin{tabular}{|c|c|c|c|}
\hline Vatations & 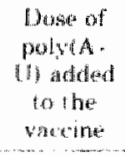 & 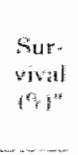 & Pval \\
\hline 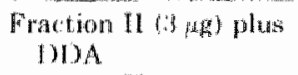 & a & 50 & \\
\hline 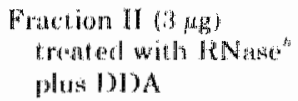 & 0 & $1 \%$ & $<0.9 M^{\circ}$ \\
\hline 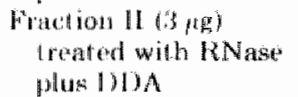 & iti & 17 & $016,63^{x i}$ \\
\hline 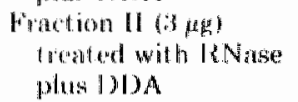 & 50 & $\ln i$ & $* 11.101^{t}$ \\
\hline 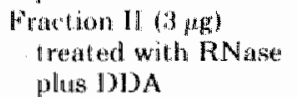 & $: 000$ & 83 & $0.04^{*}$ \\
\hline Bulfer plus DOA & 5 & 3 & \\
\hline Buffer plus DDA & 50 & 3 & \\
\hline Buffer plus DDA & 300 & 60 & \\
\hline Hulfer plus IDDA & 0 & 0 & \\
\hline
\end{tabular}
mice.

"Thath wallue was determined after challenging 30

"RN Ise, RNAwe A. ENZYGLL.

- Calcutatea with respect to fraction II phus DDA whinh was not treated whth RNase.

"Galculated wilh despect to fraction In treated with INNase plus DDA without poly(A.11, added to the wacine,

"Colculated with respect 10 buffer plus DDA to which 300 un af poly (A. U) wh added.

astontated with increasing titers of antibodies to I. $\mathrm{I}$ 's and increasing percentages of monses survival. It is conchuded that traces of LPS which ane, at least in part, responsible for the protective antivity of fartion II by the capacity to induce antibodin's 16 dids ate present in the ribosomal varceinse.

As treathent of fration II will RNase re"huced the protective activat of the ribosomal vateine, RNA might function als an adjunant or

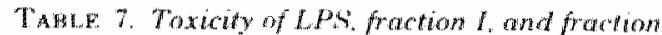
II in lead acetate sensthized mole

\begin{tabular}{|c|c|c|c|c|}
\hline Vaccine & Darae inge & $\begin{array}{c}\text { Surviwal } \\
\text { (\%) }\end{array}$ & 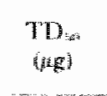 & 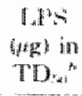 \\
\hline LPS & $\begin{array}{c}10 \\
1 \\
0.1\end{array}$ & $\begin{array}{l}3(185)^{r} \\
57(45) \\
79(34)\end{array}$ & 1.9 & 2.1 \\
\hline Wraction 1 & $\begin{array}{r}100 \\
10 \\
1\end{array}$ & $\begin{array}{l}38(47) \\
60(57) \\
87(32)\end{array}$ & 295 & 2.8 \\
\hline Fraetion II & $\begin{array}{r}10,000 \\
1,000 \\
100\end{array}$ & $\begin{array}{l}10(20) \\
71(51) \\
82(45)\end{array}$ & $1.945_{2}^{5}, 3$ & $<16$ \\
\hline Control & & $95(59)$ & & \\
\hline
\end{tabular}

"Mice were injected intravenously with $2 \mathrm{mg}$ of lead acetate mixed with the vacine.

no phe concentration of LPS was estimated by the determination of $\mathrm{KDO}$.

Number of mice is given within parentheses.

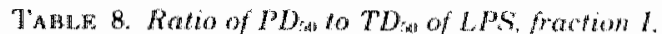
and fration II

\begin{tabular}{|c|c|}
\hline Vaccina & 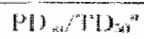 \\
\hline $11 \mathrm{l}^{4}$ & $1.2 \times 10$ \\
\hline Fraction 1 & $34 \times 10^{4}$ \\
\hline Fraction 11 & $8.1 \times 10$ \\
\hline
\end{tabular}

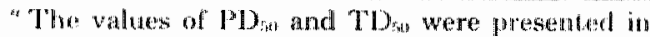
'lables 5 and 7 , respectively.

A carrier in the presentation of the contaminating cell. surfice antigens. The reduced protective activity of RNase-treated fraction II could be restored by the addition of poly(A.U). This result indicated that a synthetic polyribonucle otide could replace the adjuvant function of the ribosomal RNA and restore the capacity of cell envelope antigens to induce protective antibud. ies.

Concerming the role of RNA in the ribosomal vaccine, two observations must be discussed. The results shown in Fig. 3 suggested that protection by fraction II was associated with lower titers of antibodies to LPS than was protection by fraction I and LPS. "This might indicate that an additional protective mechanism contributed to the protective activity of fraction II. It was also observed that a high dose of poly (A. U) 6300 pug) protected mice against a lethal challenge with $P$ aeruginosa (Table 6). Simiha observa. tions were nade by Weinstein ef v1. (23), who found that injections of mice with polymosinic acid-polvey idylic at increased their resistance to bacterial infections. Preliminary experiment: have demonstrated that RNA isolated from the 


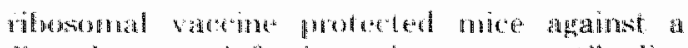
Powndommas infertion, whereas no ancibodies io LAS whe detected in the sera of these antmaxts. "Thum, there are several indications that the protective artivity of the ribosonal vaccine is oot due only to its capacity to induce antibod. as $10 \mathrm{LDS}$

As the serotype-specific protection by fraction I (6) was like ly due to the L.Psin this fraction. it was a sumpise to find a discrepanoy betwen the concentrations of LPSin the D'D of fraction Ind in the I" Dri of the purified L. PS preparation (1 ind 24 ng of $L P S$, respectively). This discrepancy might be due to the presence of different monumugens in fraction I. However, the titers of antibodies to LPS induced by fraction I and the 1. Ps vaccine were associated with similar percentages of survival (Fig. 3). Therefore, it is unlikely that protection induced by fraction $I$ is primarily due to antibodies against non-LPSlike antigens. Anothex explanation could be that the immurogenicity of the purified LPS vaccine was decreased by the purification method. Skidnure et al. (19) and Morrison and Leive (16) heve reported that several properties of LDS wete affected whan phenol extraction was used in comparison with milder extraction procedellews.

Low tuxicity has been mentioned as one of the altractive prospects of ribosomal vaccines, as thentse vanes might contain low concentrations of toxic cell envelope components (10). However, only a lew investigators have determined the toxicity of their ribosomal vaccine (2). Trial experiments have pointed out that toxic effects of the vaccines used in this study, including LPS, could be determined only when extremely high concentrations were applied. Therefore, the concontration of endotoxin in fractions I and II has baten tested in lead acetate-sensitized mice since these were reported to have an increased sensitivity to the toxic effects of LPS (18). The toxcity of non-LS-like materials in the vaccines was considered negligible. The TD of the pu. rifued LPS vaccine, fraction $I_{\text {, and fraction II }}$ we restinated to contain $2.1,29$, ard less than $1.6 \%$ of $L \mathrm{PS}$, respectively, by an independent muthod for a determination of TPS. "Thtus, the toxirity of fraction 1 was in agreement with the concestration of $L_{i}$ HS in this fraction. If the conceutration of desin the TDis of fracion II is near $1.6 \mu g$, the toxicity of fraction II could be dut to the It in this fraction. However, hagh quantities of muterial had to be injected intravengusly to reach axic dose of fraction II, which nimht have influenced the determination of the "Th of the ribosomal waceine.

Wheres the conentration of LPs in the PDY, whe purified 1 PS vane was 24 fold higher

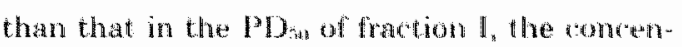
tration of LPS in the "TD of traction I and that in the purified LPS vaccine were similar. If the former result is due to a clecrease in the imnu. nogenicity of purified LPS by the extraction method, the lat ter result implies that the toxicity of LPS is not decreased proportionally by the extraction. Since the toxicity of I.PS is ascoxiated with the lipid $A$ part of the molechule. whereas the cambohydrate side chains carry the serotypespecific o antigens, toxicity and im. monogenicity may have ben affected differently by the phenol extraction.

Calculation of the $\mathrm{PD}_{\mathrm{m}} / \mathrm{TD} \mathrm{D}_{\mathrm{in}}$ ratio revealed that protection by fraction I was associated with the lowest toxicity for lead acetate-sensitized mice. This ratio was 2.4-fold higher for fraction II and 35-fold higher for the $\mathrm{L}$ PS vaccine. Thus, under these experimental conditions, protection by the ribosomal vaccine is associated with a slightly higher toxicity than is protection by fraction I. The purified LAS preparation is the most toxic vaccine.

Lieberman has prepared a purified ribosomal vaccine of $P$, aeruginosa, peak $B$, which was shown to be free of LPS by the use of labeled I.PS and by chemical means (10). This vacuine indured mouse protectiva antibodies in rabbits (11). The nature of the antigens to which these protective antibodies were directed was not clarified. No evidence was found that antibodies to L.PS were present in the antiserum to peak $B$ by means of a passive hemagglutination assay. However, the protection by the ribosomal vac cine, as well as the passive protection of mice by the antiserum to the ribosomal vaccine, wist reported to be serotype specific $(10,11)$. In view of our experience with the determination of antibudies to LPS, it is questionable whether the method used by lieberman et al. for detecting antibodies to $\mathrm{LPS}$ in antiserum 10 peak $\mathrm{B}$ thas been sensitive enough to exclude the presence of antibodies to LPS in this antiserum.

Different opinions have been expressed conceming the role of RNA in RNase-sensitive vaccines. Youmans and Youmans $(25)$ concluded that RNA was the immunogenic plinciple in the ribosomal vaccine of $M$. tuberoulosis. Araujo and Temington (3) found that protection againgt: Toxoplasma gondic would be induced with IRNA isolated from Toxoplasma cells, as well as with RNA from different soures, including synthetic polynucleotides. Tluss, RNA might nonspecifi. cally enhance rosistance against Toroplasma. Andron and Eigelsbach (1) demonstrated that an IRNage-sensitive RNA vacoine of Francisella Marensts induced opsonizing antibodies in mice. Also, Thompson and Fisenstein (20) found that an RNase-sensitive subesllular preparation 


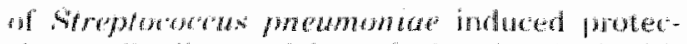

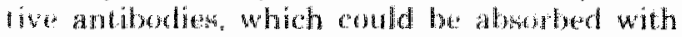
the whole bacterial aells. These tat sugnested that HNA might pay a role in the presentarion (1) konbalic antigens.

"The results prestented in this palper conlinmed the latter obserwations "The punfed ribusomal vactine of $P$ arapinosa has the capacity to induce antibodies to 1 PS, and the protective netwity of thin vacune is sersidin to RNase, suggesting that the ribosomes have the turction of a camer or an adjuwant in the plesentation of the cell surfuct antigens.

\section{ACKNOWLEDGMENT}

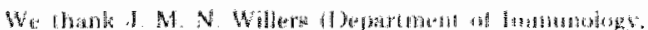

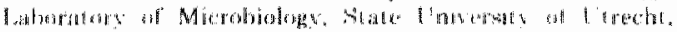

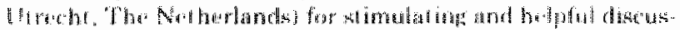
kirstes:

\section{LATEATURE (ITED}

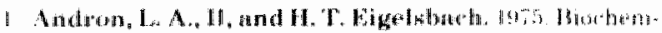

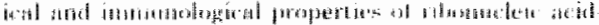

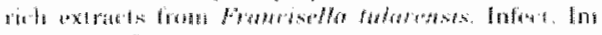

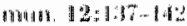

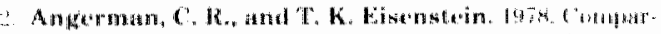

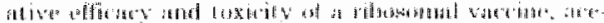

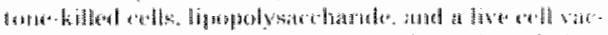

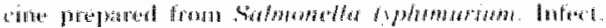

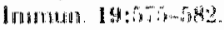

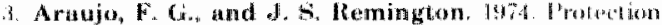

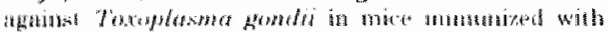

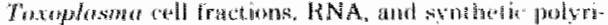

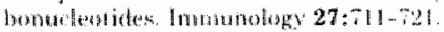

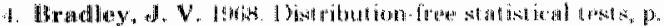

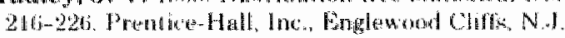

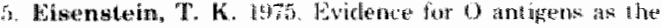

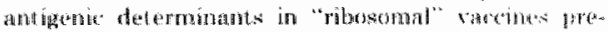

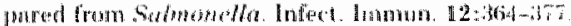

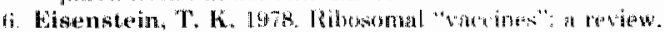

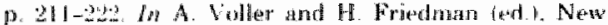

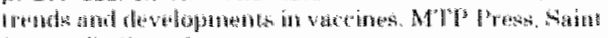

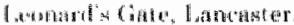

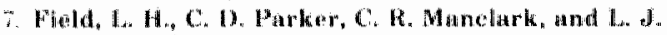
特

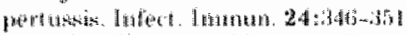

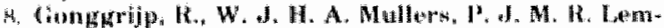

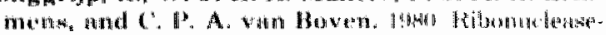

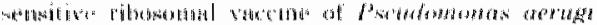
f:

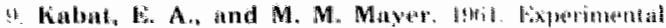

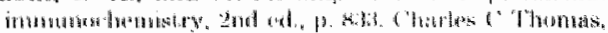

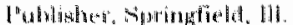

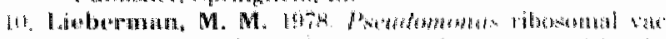

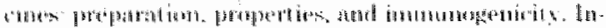

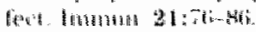

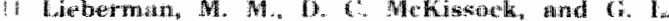

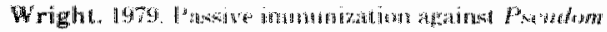

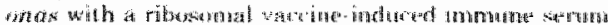

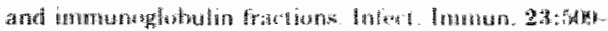
521 .

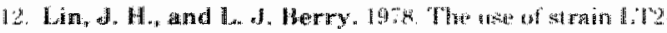

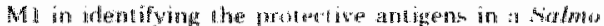

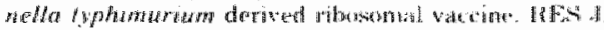

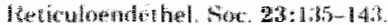

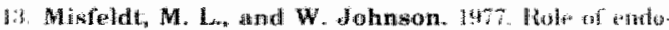

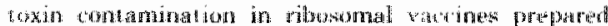

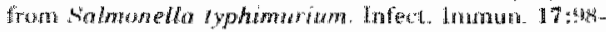
104.

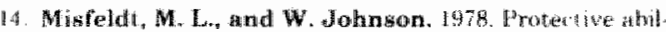

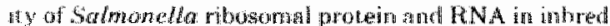

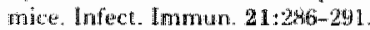

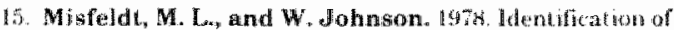
protertive cell surbate proteins lin robosomal fractions

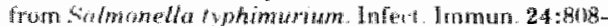
1․ 16 .

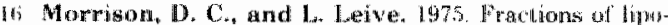

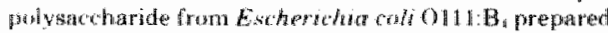

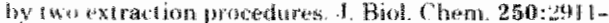

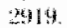

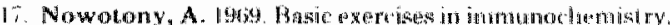

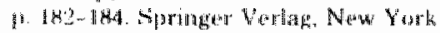

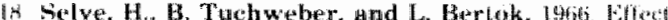

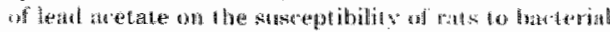

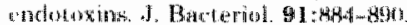

19. Shidmore, B. J., D, C. Morrison, .I. M. Chiller, and

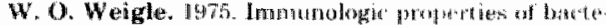

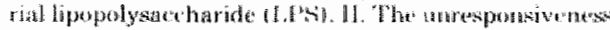

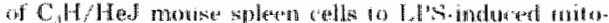
penesis is dependent ant the methot used to extrot

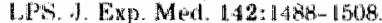

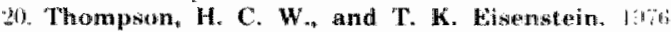

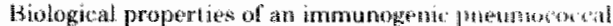

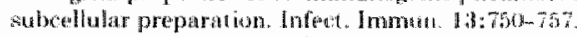

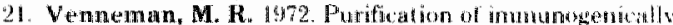

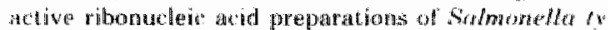

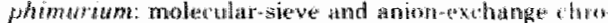
matorraphy. Infect. Immun $5.269-2 k 2$

20. Vas, J. G, J. Buys, J. C. Hanstede, and A. M. Hate

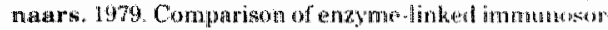

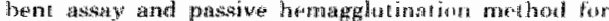

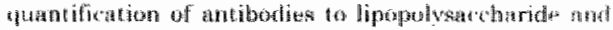

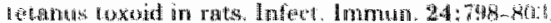

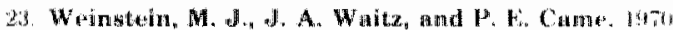

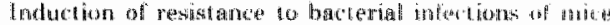

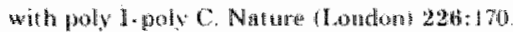

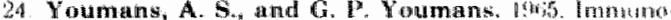

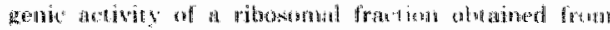

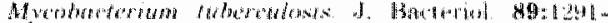
1. 2 is

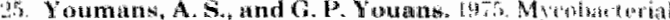

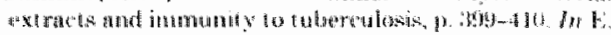

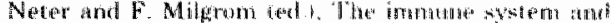

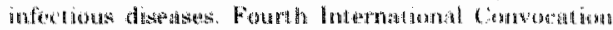

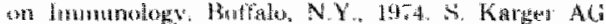

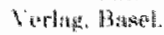




\title{
Serotype-Nonspecific Protection Induced by Ribonucleic Acid Isolated from the Ribosomal Vaccine of Pseudomonas aeruginosa
}

\author{
RINSKE GONGGRIJP* WIL J. H. A. MULLFRS, AND C. P. A. WAN BOVEN

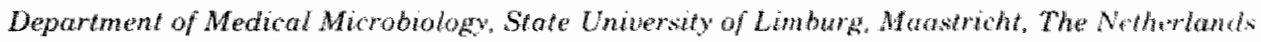

Received 27 January $1981 /$ Accepted 17 April 1981

\begin{abstract}
A ribosomal vaccine of Pseudomonas aeruginosa and a vaccine containing purified lipopolysaccharide (LPS) were compared with respect to their capacity to protect mice against a lethal challenge with $P$, aeruginosa. The route of vaccination appeared to be important for the protective activity of the ribosomall vaccine. Optimal protection was measured if both the immunizing and the challenge injection were given intraperitoneally. The ribosomal vaccine protected mice as early as 1 day after vaccination, and the protection lasted at least 6 days. LPS-specific antibodies were detectable 6 but not 2 days after vaccination. The ribosomal vaccine protected mice also against a heterologous serotype of Psin domonas. Injection of purified LPS did not protect mice earlier than at way 3 , and the protection induced by LPS was serotype specific. Ribonucleic acid (RNA) isolated from the ribosomal vaccine hat the same protective properties as the ribosomes. RNA induced serotype-nonspecific protection as quickly as I day after injection, and the protection lasted at least 6 days. However, the capacity to induce antibodies to LPS was lost or reduced. It is concluded that the serotype. nonspecific protection induced by RNA and the serotype-specific protection induced by LPS are due to different mechanisms. Experiments with combined vaccines containing RNA and LPS demonstrated that the addition of RNA to LPS resulted in a slight increase in LPS-specific antibodies. The data presented indicate that both the serotype-specific protection induced by LPS and the serotype-nonspecific protection induced by RNA contribute to the protertive activity of the ribosomal vaccine.
\end{abstract}

Protective vaccines have been prepared from the ribosomes or ribosomal extracts of many different microorganisms, including Mycobacte. rium tuberculosis, Salmonella typhimuriam, Streptococcus pnewnoniae (5), and Pseudomonas aeruginosa $(9,16)$. "The diversity" of the microorganisms from which protective ribosomall preparations could be prepared has raised the question of whether the ribosomes have a unique function in the induction of an immune response. However, several investigators recently concluded that the protective activity of their ribosomal vaccines was due to contaminat. ing cell envelope antigens $(6,17,18)$. Only a few experiments with ribosomal vaccines vielded evidence to support the idea that the ribosomes are required for the protective activity of the ribosomal waccines $(1,2,22)$.

In previous reports, a ribosomal vaccine of $P$. aeruginosa (fraction II) was described, the protective activity of which was decreased by treatment with ribonuclease (RNase) (9). This ribosomal vaccine also induced protective antibodies to lipopolysaccharide (LPSI (10), which pointed to the presence of contaminating cell envelope componenis. Since the RNase sensitivity of the ribosomal vaccine indicated that ribonucleatc acid (RNA) was required for tho protective at.tivity of this vaccine, it was suggested that the ribosomes or RNA might act as a carrier or an adjuvant in the presentation of traces of the contaminating cell envelope antigens.

In this paper, experiments to elucidate the role of RNA are deseribed. "The ribosomal vaccine and a purified LPS vaccine were compared. The conditions for optimal protedion and the specificity of the protection wer" determined. II is shown that the ribosomal vateine induced serotype-nonspecific protection as early as I day after vaccination. Similar results were obtained with RNA isolated from the ribosomal vaccine. In addition, the protective activity of combined vaccines containing $R N A$ and LPS were compared with the protective activity ollained with RNA or LPS allone.

\section{MATERIALS AND METHODS}

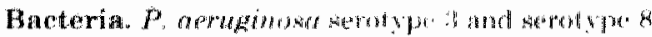




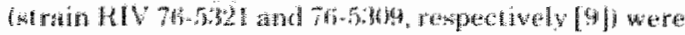
used throughut for the preparation waches and as olvallengung orgenisms.

Animals. Oubred male and female Cph $\$$ F swiss mice body weight, 18 to $20 \mathrm{~g}$ were purchased from TNO. Central Instutute for the Breeding of laboratory Animals, Zo wit., The Nothertands.

Vaccines. "The ribostmal vaceine thaction II) was obtained from a crude ribosomal preparation by molecular sieve chromatography on sepharose Cl.2B as described previcusly 19). Four hatche were pooled and further used as the ribosomat vaccine. The mount of RNA was extimat by the orenol method of Herhert al (13), using yeast IRN Boehringer Matunham Coop., Mantheiny, West Gomburyi as the standerd. The concentration of protein was determined by the follin method modified by Hartio (12)

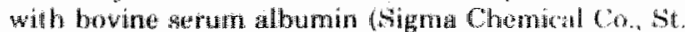

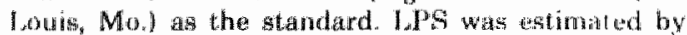
detarmination of the 2-keto-3 deoxvortonate (KDO) as follows. A sample (4 mg dry weight) was laydrolyzed with $0.014 \mathrm{~N} \mathrm{H}$.SO for $20 \mathrm{~min}$ at $100 \mathrm{C}$. K1)O was determined by the thiobarbituric acid method of Weissbanth and Hurwitz (21) with KDO (sigma Chem. ical Co.) as the standand. The amount of LPS was calculated by assuning that LPS contained $5 \%$ KDO (14). The lower limit of detection was $3 \mu$ of LAS. The ribosomal vaccine contained $632 \mathrm{\mu g}$ of $\mathrm{PNA}$ and 345 $\mu \mathrm{g}$ of protein per mg (dry weight). No LPS was detected in this preparation which implies that the ribosomal vaccine contained less than $0.8 \mu \mathrm{g}$ of LPS per mg (dry weight) (9). LPS of serotype 3 was extracted and purified as described previously (10). LPS of serotype 8 was extracted according to Galanos et al. (8) and purified by treatment with deoxyribonuclease, RNase, and pronase $\mathbf{E}$ as described for LPS of serotype 3 (10). The LPS of serotype 3 contained $24 \mathrm{Hg}$ of RNA, $80 \mu \mathrm{g}$ of protein, and 1,100 $\mathrm{gg}$ of LPS per mg (dry weight), whereas the LPS of serotype 8 contained 47 $\mu \mathrm{g}$ of RNA, $100 \mu \mathrm{g}$ of protein, and $840 \mu \mathrm{kg}$ of LPS per $\mathrm{mg}$ (dry weight).

Inolation of RNA and protein from the ribocomal vaccine. BNA was extracted from the ribosomal vacoine with phenol and sodium dodecyl sulfate and purifed a described by Poulson (19). The final RNA preparation contained 5 mg of RNA per ma and $0.042 \mathrm{mg}$ of protein per $\mathrm{ml}$. The recovery of $\mathrm{R}$ NA was 71 . Protein was isolated from the ribosomal waccine by extraction with acetic acid by the method of Hardy at al. (11). The protein supernatants were dialyzed against water overnight at $4^{\circ} \mathrm{C}$. The final preparation contained $173 \mu$ of protein per $\mathrm{ml}$, and $76 \%$ of the protein was retovered. No RNA was detectable in this preparation.

Vaccination and challenge. $P$. aeruginosa serotype 3 was the source of the vacines and the challenging onganism, unless otherwise stated. Mice were vaccinated intraperitoneally. In the first experiment, the ribosomal vaccine was also injected subcutaneouds. Where indicated, vaccines were mixed with an equal wolume $(0.1 \mathrm{ml}$ ) of the adjuvant dimethy dioctade $e^{2} y^{4}$ mmonium bromida (DDA), which was soncatcl in phosphate buffered saline (PBS) before ase (1.5 mg of DDA per ml of $12 \mathrm{~B}$ ) . The preparation of the chall soge and the determination of the 50 s lethal

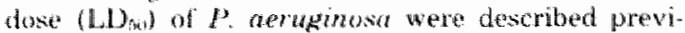

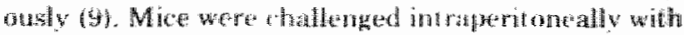

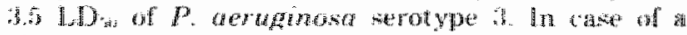
challenge with $P$. aersmings serotype 8 , the challenge dose contained $3 \mathrm{LD}$ The $\mathbb{L}$ w of $P$ aeruginosin 5321 (gerotype 3) wass $2 \times 10^{\circ}$ bacteria. The LD of $P$.

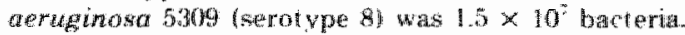
Whenever different challenging doses wero applied. it is noted in Results. Deat ths, which oc iurred principally within 2 days after challenge, we recorded 7 days arter challenge.

Antibodies to LPS. Antibodies to LPS were determined by an enzme-linked inmunanorbent asay

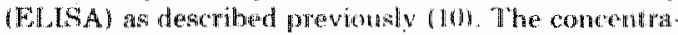

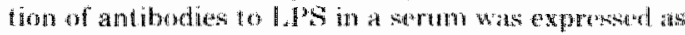
tha log: of the haghest dilution of the setum griving pewinge reation

Statistical evaluation. The signilicane loven $\mid P_{\mid}$ for protection was determined loy the Fisher ext test. as ofescribed by Bradley (3). Determinat ion of the oneside significance level $(p)$ in the pairnd comparison of antibody titers induced by different vaccines was performed by the Wilcoxon signed-rank test (15). "The? data concerning the protection induxed by combined vaccines containing RNA plus LPS and by waccines containing only RNA or LPS were analyzed to test the hypothesis that the protection by LPS acted additively 1.0 the protection by RNA. The data were represented by a threedimensional frequency table for the wariables survival, LPS dose, and RNA dose, and were andyzed by the log-linear model with only first-order interactions present (7). The significance level of the Pearson chi-square statistic (goodness of fit for the modell is indicated as $Q$.

\section{RESULTS}

Effect of vaccination route on the protective activity of the ribosomal vaccine. Mice were vaccinated either subcutaneously or intraperitoneally with different doses of the ribosomal vaccine with or without the adjuvant DDA. Six days after vaccination, all mice were challenged intraperitoneally with a lethal dose of $P$. aeruginosa. Intraperitoneal vaccination with 5 or $20 \mu \mathrm{g}$ of the ribosomal vaccine resulted in significantly higher percentages of survival than subcutaneous vaccination (Table 1). The adjuvant DDA enhanced the protective activity of subcutaneously as well as intraperitoneally injected ribosomes.

Effect of interval between vaccination and challenge on the protective activity of the ribosomal vaccine and of LPS. Mice were vaccinated with the ribosomal vaccine or with LPS at various intervals before the challenge was given (Fig. 1). The results indicated that the ribosomal vaccine protected mice as early as $\mathbb{1}$ day after vaccination, whereas with LPS the same level of protection was reached only 3 days after immunization. "The protection by the ribosomal vaccine or by LPS lasted about 9 days.

Antibodies to LPS induced by the ribosomal vaccine or by LPS at 2 or 6 days after 
TABLE 1. Affret of tacinafion route on the

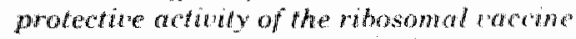

\begin{tabular}{|c|c|c|c|c|}
\hline $\begin{array}{l}\text { Vaccine } \\
\text { Type }\end{array}$ & $\begin{array}{l}\text { Dusate } \\
(\mu, t)\end{array}$ & 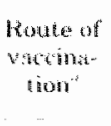 & 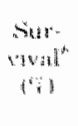 & $f^{p}$ \\
\hline Ribosomes & 5 & $\begin{array}{l}\text { s.c. } \\
\text { i.p. }\end{array}$ & $\begin{array}{r}5 \\
45\end{array}$ & $<0.6 \mathrm{~s}$ \\
\hline Ribnsomese + Hold & 5 & $\begin{array}{l}\text { s.t. } \\
\text { i.p. }\end{array}$ & $\begin{array}{r}5 \\
85\end{array}$ & $-00 \%(4)$ \\
\hline Rallowsomes & 20 & $\begin{array}{l}\text { s.c. } \\
\text { i.p. }\end{array}$ & $\begin{array}{l}20 \\
80\end{array}$ & 0.02 \\
\hline Hilussomes + EDI A & 20 & $\begin{array}{l}\text { s.e. } \\
\text { i.p. }\end{array}$ & $\begin{array}{l}15 \\
45\end{array}$ & $(0), 01$ \\
\hline Buffer + DDA & & $\begin{array}{l}\text { s.t. } \\
\text { i. }\end{array}$ & $\begin{array}{l}3 \\
0\end{array}$ & \\
\hline
\end{tabular}

"s.c., Subentaneous; i p.. intraperitoneal.

" Croups of 20 mice were rachented as indicated and challenged 6 days later.

" $P$ values with respect to subcutaneously injected vaccine were calculated by the Fisher test.

vaccination. The titer of LPS-specific antibodies was determined in the sera of mice injected intraperitoneally with the ribosomal vaccine or with LPS. Neither the ribosomal vaccine nor the LPS vaccine induced detectable antibodies to LPS 2 days after vaccination. After 6 days, both vaccines induced LPS-specific antibodies (Table 2).

Serotype specificity of the protection induced by the ribosomal vaccine or by LPS. Mice were vaccinated with the ribosomal vaccine or with LPS derived from $P$. aeruginosa serotypes 3 and 8 . Two or six days after vaccination, all mice were challenged with serotype 8 Pseudomonas (Table 3). The ribosomal waccines from both serotypes protected the mice to the same extent at 2 days after vaccination, whereas no protection was obtained with LPS. Six days after vaccination, only the LPS derived from the homologous serotype protected the mice, whereas both of the ribosomal vaccines induced significant protection. Thus, at 2 days as well as at 6 days after vaccination, the ribosomal vaccine derived from serotype 3 protected mice against a heterologous challenge. Six days after vaccination, the protection afforded by the homologous ribosomal vaccine may have been betver than the protection by the heterologous ribosomal vaccine, although the difference between the percentages of survival was not statistically significant $(P=0.1$ ).

Protective activity of RNA and protein isolated from the ribosomal vaccine. To oblain information about the nature of the protective components in the ribosomal vaccine, the protective activity of RNA and protein isolated from the varcine was tested. IRNA protected mice against a lethal wallenge with thathe art. nosa (Table 4). The amount of PNA required for protection corresponded to the amoum of RNA in protective doses of the ribosonat vac. cine. Also, RNA protected mice as early as 1 day after vaccination (Fig. 1). Protein isolat od from the ribosomal vaceine did not protect mine whether it was combined with the adjuwant DDA or not. Protection by the ribomomal vace. cine 6 days after vaceination was assercated with the presence of antibodits to LPS rable $2: 101$. In contrast, RNA protected mice is days after vaceination, whereas no antibodies to LPS were detectable in their sera ("Tuble 4). The protection by RNA was not serotype specific: RNA derived from seroptye 8 Pseudomonas proutected mice against a challenge with surotype if $P$ sedofomo. nas (Tables 5 and 6 ).

Protective activity and antibodies to L.PS induced by combined vaccines containing RNA and LPS. "To investigate whether IRNA could potentiate the immune response to $1 \mathrm{MS}$, different amounts of LPS were added to RNA vaccines. The titers of antibodies to LPS and the protection induced by vaccines containing RNA plus LPS were compared with the titers of antibodies and the protection induced by vaccines containing LPS or RNA alone. All of the vaccines were incorporated in DDA.

The titers of LPS-specific antibodies which were induced by RNA plus LPS were slightly increased compared with those induced by lips alone (Tables 5 and 6 ). Determination of the one-side significance level pointed out that a positive effect of RNA on the induction of ILSspecific antibodies cannot be neglected $(p<0,06$ for titers presented in Table 5 and $p<0.0 \%$ fom titers presented in Table 6).

The protection induced by combined wacines containing LPS from the same serotype as the challenging organism in addition to RNA from either serotype was higher than the protection induced by RNA or LPS alone (Tables 5 and 6 ). In contrast, when the LAS in the combined vaccine was derived from a different serotype than the challenging strain, the presence of the heterologous LPS did not alter the protertion by RNA (Table 5).

The survival induced by combined vace ines was associated with lower titers of 1.PS-specific antibodies than the survisal induced by wactoses containing only LI's For example. a combined waceine induced $60 \%$ sumival and an LIS-specific antibody titer of 1.4, whereas $1 . P S$ indured $57 \%$ survival and an antibody titer of $2.3 \times \mathrm{CT}$ able 5). Likewise, a combined vaccine induced sor survival and an antilbody titer of 4.7. whereag L.PS induced 63\% survival and an anthody tites 
of 6.0 (19able 6). Thus, the higher protection induced by combined wacrines was not due only to the increased titers of 1.1 \%-specific antibodies.

The data on the survival induced by vaccines with different RNA and I.PS doses were statistically analyzed to test the hypothesis that the protection induced by LPS acted only additively to the protection induced by RNA. The Q (sig- nificance level of the gowdness of fit for the model) was 0.66 for the data presented in Tablle 5 , supporting the hypothesis that LPS and RNA contributed additively to the survival. The $Q$ was 0.09 for the percentages of survival presented in Table 6 indicating that the survival could not be explained by only additive protective effects of RNA and LPS.

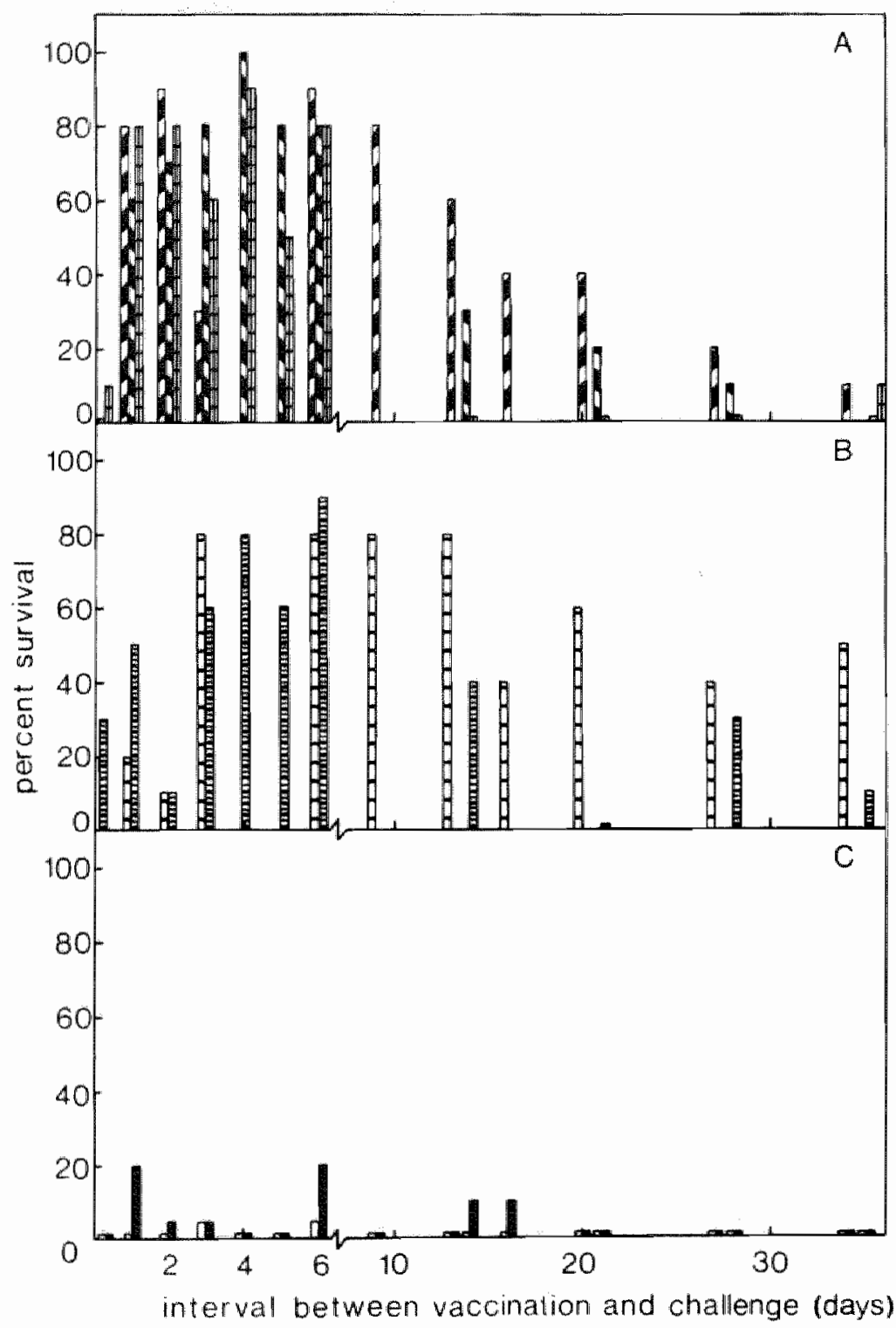

Fia. 1. Effert of intertal between taccination and challenge on the protective activity of the ribosomal bacoint and of LPS. Oroups of 10 mice each were immunized intraperitoneally on different days wath the ribosiomal waccin plus DDA or RNA plus DDA (A), with LPS (B), or with buffer or buffer plus DDA (C) AL mice were challenged at the same day wh $P$. aeruginosa. Symbols: (A) A, I ig of ribosomal vaccine plus

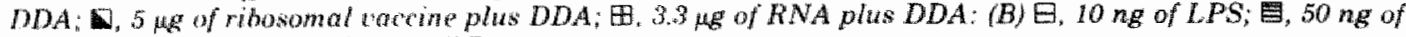
I.PS: (C) D. buffer: buffer phus DDA. 


\section{DISCUSSION}

Although efrente ribosomal vaccines have h.4: prepared from many microorganisms, the natue of the immunogen(s) in these vaccines has not been clarified. In particular, the function of the ribosomes in the vaccines has been discussed, since contaminating cell envelope antigens were found in several of the ribosomal preparations $(6,17,18)$. Previous studies of this laboratory (9) showed that a ribosomal vaccine of $P$. aeruginosa could be prepared which was sensitive to RNase, indicating that the ribosomal RNA was required for the protective activity of this vaccine. In addition, this vaccine could induce antibodies to the cell envelope component LPS (10). These results suggested that the RNA might act as a carrier or an adjuvant for cell envelope antigens. The purpose of the present study was to compare the properties of the ribosomal vaccine with those of an LPS vaccine in order to obtain more information about the function of RNA in the ribosomal vaccine.

The conditions for optimal protection by the

TABLE 2. Anthodies to LPS induced by the ritoromal vaccine or by LAS at 2 or 6 days after intraperitomeal accoination

\begin{tabular}{|c|c|c|c|}
\hline \multicolumn{2}{|l|}{ Varcine } & \multicolumn{2}{|c|}{$\begin{array}{l}\text { Loge titer of } \\
\text { antibodies to } \\
\text { I.PS }\end{array}$} \\
\hline Type & $\begin{array}{c}\text { Dose } \\
\text { (prig) }\end{array}$ & 2 days & ti days \\
\hline Ribosomes + DDA & 10 & 0.9 & 7.3 \\
\hline Ribosomes + DDA & 1 & 0.5 & 4.6 \\
\hline LPS & 0.1 & 0.9 & 8.7 \\
\hline LPS & 0.01 & 1.0 & 6.9 \\
\hline Buffer & & 1.6 & 1.3 \\
\hline Buffer + DDA & & 0.0 & 1.3 \\
\hline
\end{tabular}

"Determined by WLISA. Each value wepresents the mean of two determinations on different pooled sera of five mice. ribosomal vaccine were determined first. "Th" efficacy of the ribosomal vacche was infuenced by the route of vaccination. When the ribosomal vaccine was injected intraperitoneally, lower concentrations of the vacuine were required 10

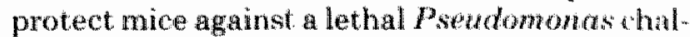
lenge in comparison with subcutaneous injec. tion. In subsequent experiments, all vacciness were injected intraperitoneally so that vaccina. tion and challenge were given by the same route.

The ribosomal vaccine protected mice as soon as 1 day after injection. Two days after" vaccination with either the ribosomal vaccine or LPS, no antibodies to LPS could be detected in the sera of the mice. At this time, the ribosomal vaccine protected mice also against a heterolo.

TARLE 4. Protective activity of RNA and protein isolated from the riboswmal raccine

\begin{tabular}{|c|c|c|c|c|c|}
\hline \multicolumn{2}{|l|}{ Vabcine" } & \multicolumn{3}{|c|}{ Survival } & \multirow{2}{*}{ 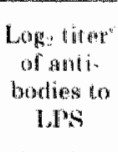 } \\
\hline Type & $\begin{array}{l}\text { Doxige } \\
(\mu g)\end{array}$ & $\%$ & $\begin{array}{c}\text { No. } \\
\text { chas. } \\
\text { lomged }\end{array}$ & $\underset{v a l}{P}$ & \\
\hline $\begin{array}{l}\text { Ribosomes + } \\
\text { D) }) \text { A }\end{array}$ & 5 & 85 & 20 & $<0.01$ & 5.0 \\
\hline $\mathrm{RNA}+\mathrm{DDA}$ & 3.3 & 54 & 17 & $<0.01$ & 0.1 \\
\hline $\mathrm{RNA}+\mathrm{DDA}$ & 5 & 65 & 20 & $<001$ & 20 \\
\hline Protein + DDA & 5 & 10 & 30 & 0.3 & 0.9 \\
\hline Jrotein + 1)DA & 15 & 13 & 30 & 0.2 & 0,0 \\
\hline Protein & 15 & 0 & 30 & 1.0 & 0.0 \\
\hline Buffer + DIDA & & $d$ & 30 & & 1.0 \\
\hline Buffer & & 0 & 30 & & 0.1 \\
\hline
\end{tabular}

"All vaccines were derived from serolype is $P$ stu. domonas.

* Mice were challenged with $P$, aeraginosa serolype 36 days after an intraperitoneal vaccination.

Dettermined in pooled sera of five mice by FILISA. Each value represents the mean of lwo determina. tions.

${ }^{2} P$ values with respect to the corresponding conn trols (buffer or buffer pllus DDA) were calculnted by the Fisher test.

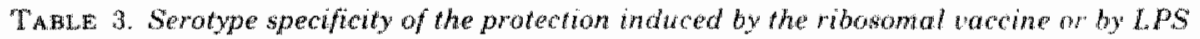

\begin{tabular}{|c|c|c|c|c|c|c|c|}
\hline \multicolumn{2}{|l|}{ Viane } & \multicolumn{6}{|c|}{ Survivals" } \\
\hline \multirow[b]{2}{*}{ TYYot } & \multirow[b]{2}{*}{$\begin{array}{l}\text { Dose: } \\
\text { (y) }\end{array}$} & \multicolumn{3}{|c|}{2 days } & \multicolumn{3}{|c|}{ thetarion } \\
\hline & & $\%$ & $\begin{array}{l}\text { No. ehal } \\
\text { loriged }\end{array}$ & $P$ value $e^{x^{*}}$ & r & $\begin{array}{c}\text { No ind } \\
\text { lenged }\end{array}$ & Pylluge \\
\hline Ribonomes (serotype 8 ) + DDA & 5 & 77 & 30 & $<0.01$ & 57 & 30 & $<0.0 \|$ \\
\hline 1. $P S$ (serolype 8$)$ & 0.05 & 3 & 30 & 0.8 & 75 & 20 & $<0.01$ \\
\hline Ribosomes (sterotype 3$)+D D A$ & 5 & 70 & 30 & $<0.01$ & 37 & 30 & $<0.01$ \\
\hline LPS (serotype 3! & 0.05 & 3 & 30 & 0.8 & 10 & 20 & 0.16 \\
\hline Buffer + DDA & & 27 & 30 & & 1 & 30 & \\
\hline Buffer & & 3 & 30 & & 0 & 30 & \\
\hline
\end{tabular}

"Mice were challenged with $P$. aerughosa serotype 8 at 2 or 6 days after intraperitonest wacination with homologous or heterologous vacines.

${ }^{\circ} P$ values with respect to the corresponding controls (buffer or buffer plus DDA were calculated by the Fisher test. 


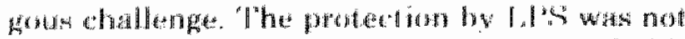
evident for 3 days after vaccination, and this protedtion was serotype specific. It is concluded that the ribosomal vaceine could induce early, serotype-nonspecific protedtion which was likely to be different from the serotype-specific protection induced by LPS.

The ribosomal vaccine also induced serotypenonspecific protection 6 days after vaccination. Although 2 days after vaccination the homologous and heterologous ribosomal vaccine prom tected mice to the same extent the results suggested that 6 days after vaccination higher percentages of survival could be induced with the ribosomall vaccine derived from the challenging organism than with the heterologous ribosomal vaccine. This was best explained by the finding that 6 days after vaccination detectable amounts of antibodies to LPS were induced by the ribosomal vaccine.

In a previous report, it was demonstrated that the subcutaneously injected ribosomal vaccine derived from serotype 3 could not protect mice against a challenge with serotype 8 Psetudomonas (9). Preliminary experiments supported the explanation that this difference was due to the route of vaccination.

RNA and protein were isolated from the ribosomal vaccine to determine whether the pro-

TABne 5. Protectise activity and antibodies to LPS indweed by combined vaccines containing RNA and LPS from P. aerugunosa seratype $8^{\circ}$

\begin{tabular}{|c|c|c|c|c|}
\hline \multicolumn{2}{|r|}{ Dose } & \multirow{2}{*}{$\begin{array}{c}\text { Logs titer" of } \\
\text { antibodies to } \\
\text { L.PS }\end{array}$} & \multicolumn{2}{|c|}{$\begin{array}{l}\text { Survival (o) after } \\
\text { challenge with: }\end{array}$} \\
\hline $\begin{array}{l}\text { RNA } \\
(\mu g)\end{array}$ & $\mathrm{I}_{\mathrm{H}} \mathrm{B}$ (ngs) & & $\begin{array}{l}\text { Sero- } \\
\text { Eype } 8^{-}\end{array}$ & $\begin{array}{l}\text { Sero. } \\
\text { type } i^{f t}\end{array}$ \\
\hline 5 & & 1.0 & 43 & 45 \\
\hline \multirow[t]{2}{*}{$\$$} & 0.01 & 0.8 & & 50 \\
\hline & 0.01 & 0.9 & & \\
\hline \multirow[t]{2}{*}{ : } & 0.1 & 1.0 & & 45 \\
\hline & 0.1 & 0.4 & & \\
\hline \multirow[t]{2}{*}{5} & 1.0 & 1.4 & 60 & 58 \\
\hline & 1.0 & 0.9 & 23 & \\
\hline \multirow[t]{2}{*}{5} & 10 & 3.6 & 79 & 55 \\
\hline & 10 & 2.3 & 57 & \\
\hline 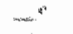 & - & 1.6 & 10 & 0 \\
\hline
\end{tabular}

"All vaccines were incorporated in DDA

"The log. titer of antibodies to LPS derived from 1.. arerginosa sutyotype 8 was determined in sera of nice o days after vactuation. Wach value represents the mean of three determinations on different pooled sera of live mice.

Each value was determined after challenging 30 mice with an inoculum containing $3 L D$ of $P$. arerugrnosa serotype 86 days after vaccination.

Fach value was determined after challenging 20 mice with all inoculum containing 3.5 LD of $P$. aeruginosa serotype 36 days after vaccination.

"- Cotrols infected with buffer in DDA.

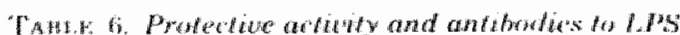

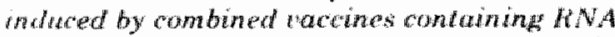
fresm saprotype 8 and $L P S$ from serotype it of $P$. aeruginosint

\begin{tabular}{|c|c|c|c|}
\hline \multicolumn{2}{|c|}{ Dersie } & \multirow{2}{*}{$\begin{array}{l}\text { Logg }_{2} \text { iterer } \\
\text { of annt- } \\
\text { bodies to } \\
\text { LPS }\end{array}$} & \multirow{2}{*}{$\begin{array}{c}\text { Survival } \\
\text { (ow inter } \\
\text { challenge } \\
\text { with sero } \\
\text { lype } 3\end{array}$} \\
\hline $\mathrm{BNA}(\mu \mathrm{g})$ & LPS Ing & & \\
\hline 5 & & 1.1 & 40 \\
\hline \multirow[t]{2}{*}{ 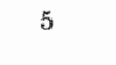 } & 1 & 4.7 & 80 \\
\hline & 1 & 4.0 & 13 \\
\hline \multirow[t]{2}{*}{5} & 10 & 6.8 & 87 \\
\hline & 10 & 6.0 & 63 \\
\hline it & - & 0.8 & 3 \\
\hline
\end{tabular}

"All vaccines were incorporated in DDA.

"The $\log _{2}$ titer of antibodies to LPS derived from $P$. aeruginosa serotype 3 was determined in sera of mice to days gfter waccination. Fach value represents the mean of three determinations on different pooled sera of five mice.

"Each value was determined after challenging 30 mice with an inoculum containing $4 \mathrm{LD}_{5 *}$ of $P$. aerughnosa serotype 36 days after vaccination.

"-. Controls were injected with buffer in DDA.

tective activity of the ribosomes remained asso. ciated with one of these two components. No protection was obtained with protein isolated from the ribosomal vaccine. In contrast, RNA exhibited the same protective properties as the ribosomal vaccine. RNA induced protection as quickly as 1 day after vaccination, and the protection by RNA was not restricted to the homologous serotype. The concentration of RNA which was required to induce protection was similar to the concentration of RNA in protective doses of the ribosomal vaccine. However, in contrast to the ribosomal vaccine, RNA did not induce antibodies to ILPS 6 days after vaccination. Probably the concentration of contaminating LPS in the ribosomal waccine had been reduced during the isolation of RNA below the level that was required to induce antibodies.

Combined vaccines containing RNA plus LPS were used to investigate the function of RNA in the ribosomal vaccine. The addition of RNA to an LPS vaccine resulted in higher concentrations of LPS-specific antibodies. Also, the protection by combined vaccines containing RNA and LPS which was derived from the challenging serotype was increased in comparison with the protection induced by RNA or LPS alone. The higher protection induced by combined vaccines was in part serotype specific, since the protection by RNA was not affected by the addition of LPS from a different serotype than the challenging strain. The protection by combined vaccines is not due only to the increased titer of LPS-specific antibodies. The percentages of survival in. 


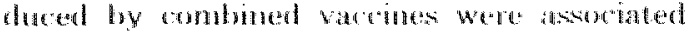

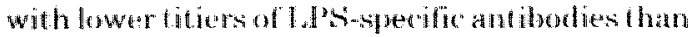
the surval indued by las alone. A previous report demonstrated that the protection induced by the ribosomal vaccine was associated with lower titers of LPS-specific antibodies than the protection induced by purifed LPS $(10)$. It is concluded that RNA contributed to the protective activity of the ribosomal vaccine in two ways. RNA induced serotype-nonspecific protection which was independent of the presence or absence of LPS-specific antibodies. In addition, RNA enhanced the production of antibodies to contaminating cell envelope antigens, i.e., L.PS.

Preliminaty experiments pointed out that the protection induced by $\mathrm{RNA}$ was not restricted to the Pseudomonas species; Pseudomonas RNA could also protect mice against a challenge with Escherichia coli. Thus, the protection induced by RNA might be nonspecific.

Coppel and Youmans (4) reported that the mycobacterial ribosomal fraction which was incomporated in Freund incomplete adjuvant prorected mice against a lethal challenge with Kleb. siella pneumoniae during 4 days after immunization. No protection was obtained against a challenge with Listeria monocytogenes. Weinstein et al. (20) demonstrated that nonspecific protection against several microorganisms was also obtained $\mathbb{l}$ day after injection of polyinosinic-polycytidylic acid without adjuvant. Araujo and Remmington (2) found that synthetic polynucleotides and RNA extracted from macrophages of mice protected mice against a challenge with Toxoplasma gondii at 30 days after the injection of RNA. Macrophages of mice which were immunized with RNA extracted from toxoplasma cells resisted a challenge with L. monocytogenes in vitro. Thus, although sevm eral investigators found that RNA could induce nonspecific protection in mice against different microorganisms, the results varied with respect to the duration of the protection, the degree of protection against particular microorganisms (i.e., L. monocytogenes), and several other aspectis.

The present report demonstrates that serotype-nonspecific protection induced by $R N A$ isolated from the ribosomal vaccine of $P$. aerugi. nosic could come to expression only under cer" tain conditions, i.e. the use of an adjuvant, intraperitoneal injection of the vaccine (via the same route as the challenge was given), and injection of the challenge within 6 davs after vaccination. These conditions might provide an explanation of why several investigators of ribosomal vaccines have not found any evidence that RNA contributes to the protective activity of their ribosomal prepatations $(6,16,17,18)$. As the (serotype) nonspecific prutection by $R$ NA Was induced as early as $\mathbb{1}$ day after vaccination. the protection mav have been due to a nonspe. cife increase in the resistance of the host by an effect on the phagocytic systen. The data in Table 5 suggested that the protective effects of RNA and LPS acted additively. Therefore, the protective activity of the ribosomal vaccine might be the result of an enhanced phagocytic capacity of the host induced by RNA and of the presence of serotype-specific antibodies which facilitated the phagocytosis of the organism from which the ribosomal vaccine was isolated.

\section{ACKNOWLEDGMENTS}

We thank Arno M. M. Mujitiens (Department of Biophysics, State University of Limburg. The Netherlands for the statistical analygis. We also thank B. Dawies (Department of Bacteriology, De Wever Hospital, Heerlen, The Netherlands) and J. M. N. Willers (Department of Immunology, Laboratory of Microbiology. State University of Vireabu. The Nethep. lands) for critically reading the manuscrift.

\section{LTTEATURE CTTED}

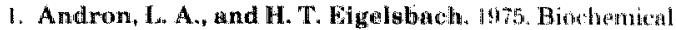
and immunological properties of ribmucteic ard-rieh extracts from Francisplla twarensis. Infect. Immun. 12: $1137-142$.

2. Araujo, F, G., and J, S. Remmington, 1974 . Brobetion againgt Toxoploswat gondi in mio innmunised with Toxoplasma cell fractions, RNA, and synthetic polyribonucleotides. Immunology $27: \pi 11-721$.

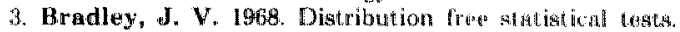
Prentice-Hall, Inc. Englewood Cliffs, N. $\%$,

4. Coppel, S., and G. P. Youmans. 1969 specificity of acquired resistance produced by immunization with mycobacterial cells and mycobacterisal fractionss, J. Barieriol $97: 114-120$.

5. Eisenstelm, T. K. 1978 . Ribosomal wecines: a reviow, $p$.

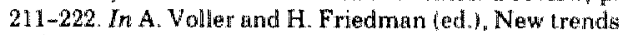
and developments in vaccines MTP Press Limilod, $8 \mathrm{i}$. Learard Gate. England.

6. Field, L. H, C. D. Parker, C. R. Manelark, and L. J. Berry, 1979 . Evaluation of a ribosamal vaceine against. pertussis. Infect. Immun $24: 346-351$.

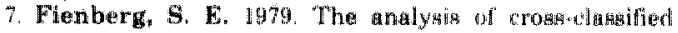
centegorial data. The MIT Prese, Levindon, Fingtand.

8. Gallanos, C., O Luderitz, and $O$. Weatphal. 1969 A rew method for the extraction of $K$ lipopolvench rides. Eur. J. Biochem. 9:245-249.

9 Conggrijp, R., W. J. H. A. Mullers, P. J. M. R. L. ni-

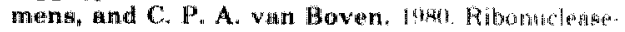

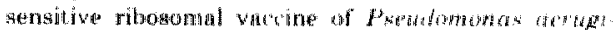
mosas. Intect. Immun $27: 204-210$.

10. Gongurijp, R, M. P. W, Volleberg, P. J, M. R. Lemmens, and C. P. A. van Hoven. Ligh. Evidlence fol

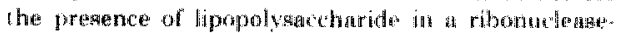

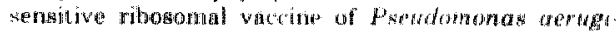
nowa. Infert. Immun. $31: 4 y_{3}-905$.

11. Hardy, S. J. S., C. G. Kurland, F". Voynow, and $G$.

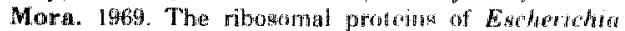

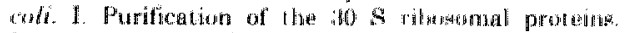
Hiochemistry $8: 2897-290 \%$.

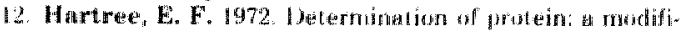
cation of tha Lowry method that ance a linew photo. metrie responsie. Antal. Biocthem. 48,42-427.

11. Herbert, D., P. H. Phipps, and It. F. Strange. 1971 


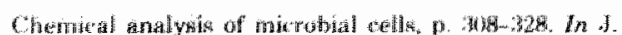

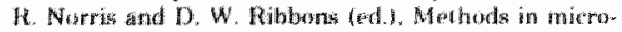

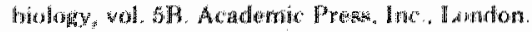

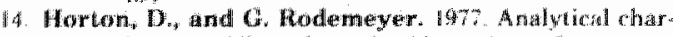

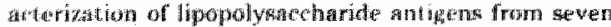

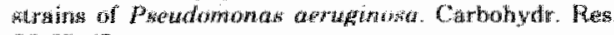
$55: 13,4=2$

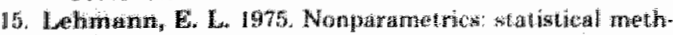

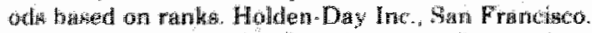

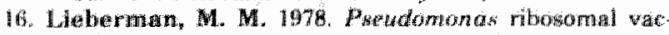
cines preparation, properties, and immunogerticily. In feet. Imroum. 21:76-686

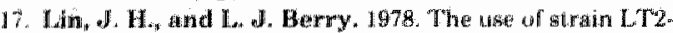
MI in identifying the protectse antigens in a salmo. nello typhimurium derived ribomonal vaccine. RES d Reticulondot hel ane: $23: 135-14 \%$.

In Miafeldt, M. Lu, and W. Jolhnson. 1978. Identification of protective cell surface proteifu in ribosomal fraction

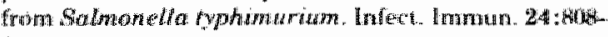
816.

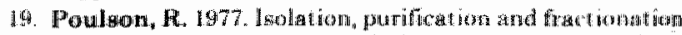
of RNA. p. 343-344. In P. R. Sitewart and D. S. Letham (ed). The ribonudeic acids. 2nd ed. Springer Vurlag Inc, New York.

20. Weinstein, M. J. $J_{*} A$ Waitz and P. E. Came. 1970. Induction of pesistance to bacterial infections of nuivo with poly" poly C. Nature (London) 226:170.

21. Weissbach, A., and J. Hurwitz. 1959. The formation of 2. keto-3 deoxyheptonic acid in excracts of Escherichia coli B. 1. Identification. J. Bial. Chem. 234:705 709.

22. Youmans, A. S., and G. P. Youmang. 1966. Effect of trypsin and ribonuclease on the immunogenic activity of ribosomes and ribonucleic acid isolated from $M y c o-$ bacterium tuberculosis. J. Bacteriol. 91:2146-2154. 


\section{Protection induced by ribosomal ribonucleic acid of Pseudomonas aeruginosa not due to contaminating lipopolysaccaride.}

\section{SUMMARY}

The protective activities of a purified ribosomal vaccine, ribonucleic acid (RNA) isolated from the ribosomes, and purified lipapolysaccharide (LPS) from Pseudomonas aeruqinosa were compared, using different approaches. In the RNA preparation isolated from purified ribosomes no LPS was detected with the limulus test. Injection of RNA protected mice against $P$. aeruginosa without inducing LPS specific antibodies. $\mathrm{C}_{3} \mathrm{H} / \mathrm{HoJ}$ mice which are relativeIy insensitive for the protective activity of LPS could be protected with the ribosomal and RNA preparations. Defective LPS, containing lipid $A$ and some of the core polysaccharides, was isolated from a LPS-defective mutant strain of P. aeruginosa, PAC 605. This LPS had I000 fold lower protective activity than the LPS from PAC IR, the parent strain of PAC 605. The RNA preparations from ribasomes of PAC 605 and PAC IR induced low, but similar percentages of survival. The protective activity of RNA from ribosomes of $P$. aeruginosa was nonspecific since mice were also protected against challenge with Escherichia coli. RNA from ribosomes of P. aeruginosa, E. coli and the non-LPS containing Saccharomyces cerevisiae had similar protective activities. No protection was obtained with the RNA from the E. coli phage MS2.

In conclusion: the protective activity of ribosomal RNA is not due to 0 antigens of contaminating LPS, nor to the mitogenic activity of fragments of LPS in the RNA preparation. The protective activity of the RNA preparations could not be correllated with the integrity of the RNA molecules.

\section{INTRODUCTION}

Effective ribosomal vaccines have been prepared from many different microorganisms (8). Youmans and Youmans have prepared a non-living highly potent ribosomal vaccine from Mycobacterium tuberculosis (29). Some ribosomal vaccines induced serotypenonspecific protection $(20,24)$ and ribosomal vaccines are gene- 
rally believed to be relatively non-toxic (1). Although many efforts were devoted elucidating the nature of the protective components in ribosomal vaccines, no satisfactory explanation has been found. Recently several authors have concluded that contaminating cell envelope components were the principal immunogens in their ribosomal vaccines $(9,19,21,23)$. In that instance vaccine preparations containing bacterial cell envelope components have many advaritages over laboriously prepared ribosomal vaccines. Several ribosomal vaccines from Gram-negative bacteria have been found to be contaminated with lipopolysaccharide (LPS; 7, 12, 19). The most probable cell envelope component contaminating ribosomal vaccines from Pseudomonas aeruginosa is also LPS. A few nanograms of LPS from this microorganism appeared to be sufficient to protect mice against a lethal challenge with the homologous microorganism (22). In previous experiments we demonstrated that ribosomal RNA and LPS both contributed to the protective activity of a ribosomal vaccine from $P$. aeruginosa. The RNA induced serotypenonspecific protection as early as one day after injection, while traces of contaminating LPS in the ribosomal vaccine contributed to the protective activity by the induction of LPS-specific antibodies (13).

In this study it is demonstrated that the protective activity of RNA in - or isolated from - the ribosomal vaccine is not due to contaminating LPS or fragments of LPS. The experiments provided also some information on the demands on the molecular structure of RNA which is necessary for the induction of protection.

\section{MATERIALS AND METHODS}

Bacteria. P. aeruginosa serotype 3 (strain RIV 76-5321) (11) was used for the preparation of the vaccines and as the challenging organism unless otherwise stated. P. aeruginosa serotype 8 (strain RIV 76-5309) was described previously (11). The P. aeruginosa strain PAC IR serotype 3 (18) and the LPS defective mutant PAC 605 which was derived from PAC $I R$ were a gift of dr. P.M. Meadow (University College London, England). The defective LPS of PAC 605 contained the lipid A, 2-keto-3-deoxyoctonic acid (KDO), heptose, galactosamine and alanine characteristic of the wild type LPS but it lacked the neutral sugars of the LPS core as well as the 0 antigenic carbohydrate side chains (18). The Escherichia coli strain 25922 which was used as a challenging organism was isolated by $\mathrm{dr}$. E.E. Stobberingh from patient material.

Animals. Dutbred male and female Cpb SE Swiss mice (body weight $18-20 \mathrm{~g})$ were purchased from TNO, Central Institute for the breeding of laboratory animals, Zeist, The Netherlands. Inbred male and female $\mathrm{C}_{3} \mathrm{H} / \mathrm{HeJ}$ and $\mathrm{C}_{3} \mathrm{Heb} / \mathrm{FeJ}$ mice were obtained from Jackson Laboratories, Bar Harbor, Maine. 
Vaccines. The preparation of the crude ribosomal vaccines and the isolation of purified ribosomes (fraction II) by molecular sieve chromatography were described previously $(11,12)$. The amount of RNA was estimated by the orcinol method (15), using yeast RNA (Boehringer Mannheim Corp., Mannheim, West Germany) as the standard. The concentration of protein was determined by the Folin method modified by Hartree (14) with bovine serum albumin (Sigma Chemical Co., St. Louis, Mo.) as the standard.

LPS was estimated by the determination of KDO. In brief: a sample was hydrolyzed with $0.014 \mathrm{~N} \mathrm{H}_{2} \mathrm{SO}_{4}$ for $20 \mathrm{~min}$ at $100^{\circ} \mathrm{C}$. $K D O$ was determined by the thiobarbituric acid method (27) with KDO (Sigma Chemical Co.) as the standard. The amount of LPS was calculated by assuming that LPS contained 5\% KDO (16). LPS from PAC IR contained $3 \%$ KDO (4); LPS from PAC 605 contained 6.75\% KDO (P.M. Meadow, personal communication). The crude ribosomal preparation of $P$. aeruginosa strain 5321 contained 46\% RNA and 56\% protein (11); the purified ribosomal preparation consisted of $63 \%$ RNA and $35 \%$ protein (13). No KDO was detected in purified ribosomes from P. aeruginasa strain 5321, PAC 1R, or PAC 605.

The extraction of RNA from the crude ribosomal preparation was performed in the same way as the extraction of RNA from the purified ribosomes, which was described previously (13). Both preparations of RNA contained $2{ }^{\text {gr protein. }}$

LPS from $P$. aeruginasa (strain 5321) and the defective LPS from the mutant strain PAC 605 were extracted according to the method of Galanos (10), while LPS from P. aeruginosa strain PAC 1R was extracted according to the method of Westphal (17). The LPS preparations were purified with the aid of ribonuclease and pronase as was described previously (12). The LPS from P. aeruginosa strain 5321 contained 93\% LPS, 4\% protein and 3\% RNA. The LPS from $P$. aeruginosa strain PAC IR contained 135\% LPS, $14 \%$ protein and $3 \%$ RNA. The LPS from strain PAC 605 was estimated to contain $60 \%$ defective LPS, 16\% protein and 4\% RNA. Ribosomal RNA from E. coli MRE 600 and RNA from the phage MS2 were purchased from Boehringer. The ribosomal RNA from Saccharomyces cerevisiae and ribosomal RNA from E. coli R-13 were obtained from P.L. Biochemicals Inc., Milwaukee, Wisc.

Enzyme linked immunosorbent assay (ELISA). Antibodies to LPS were determined by an ELISA as described previously (12). The concentration of antibodies to LPS in a serum was expressed as the $\log _{2}$ of the highest dilution of the serum giving a positive reaction.

Limulus test. Determination of LPS with the Limulus amebocyte lysate pyrogent (lot OHT, Mallinckrodt Inc., St. Louis, Mo.) was performed according to the manufacturer's instructions. 
Vaccination and challenge. Mice were vaccinated intraperitoneally and were challenged six days later via the same route unless otherwise stated. Vaccines containing ribosomes or RNA were mixed with an equal volume $(0.1 \mathrm{ml})$ of the adjuvant dimethyldioctadecylammonium bromide (DDA) (Eastman Kodak Co., Rochester, N.Y.), which was sonicated in phosphate buffered saline (PBS) before use (1.5 mg DDA per m1 PBS). Bacteria which were used for challenge were inoculated from an overnight culture in fresh Trypticase soy broth (BBL. Microbiology Systems, Cockeysville, Md) at a final concentration of $1.5 \times 10^{7}$ bacteria per $\mathrm{ml}$ and grown for $3 \mathrm{~h}$ at $37^{\circ} \mathrm{C}$ under shaking. The preparation of the challenge and the determination of the 50\% lethal dose $\left(L D_{50}\right)$ of $P$. aeruginosa were described previously (11). The challenge dose of P. aeruginosa strain 5321 contained $6.4 \angle D_{50}$ (i.e. $7 \times 10^{7}$ colony forming units (CFU)). A challenge dose of $\mathrm{P}$. aeruginosa strain 5309 contained $1.1 \times 10^{8}$ CFU per mouse. The challenge dose of $E$. coli strain 25922 was higher at 2 days after vaccination than at $5 i x$ days after vaccination and contained $4 \times 10^{8} \mathrm{CFU}$ and $1.2 \times 10^{8}$ CFU respectively. $\mathrm{C}_{3} \mathrm{H} / \mathrm{HeJ}$ and $\mathrm{C}_{3} \mathrm{Heb} / \mathrm{FeJ}$ inbred mice were challenged with $3 L_{50}(8 \times$ $\left.10^{7} \mathrm{CFU}\right)$ of $P$. aeruginosa strain 5321 .

Deaths, which occurred principally within two days after challenge, were recorded till seven days after challenge.

(Poly)acrylamide gel electrophoresis of RNA. RNA samples were heated at $60^{\circ} \mathrm{C}$ in $60_{\%}^{\circ}$ formamide for 4 min prior to electrophoresis. The gels contained 3\% acrylamide, $0.15 \%$ bis acrylamide, $0.1 \% N, N, N^{\prime}, N^{\prime}-$ Tetramethylethylenediamine (TEMED) and $0.01 \%$ persulphate. The electrophoresis buffer $\mathrm{pH} 7.8$ consisted of $0.04 \mathrm{M}$ tris(hydroxymethy 1 ) aminomethane, $0.02 \mathrm{M}$ sodium acetate, $0.002 \mathrm{M}$ ethylenediaminetetraacetic acid (EDTA) and $0.1 \%$ sodium dodecyl sulphate. Pre-electrophoresis was performed for $2 \mathrm{~h}$ at $5 \mathrm{~mA}$ per gel. Samples containing approximately $2 \mu \mathrm{g}$ RNA in $10 \%$ sucrose were layered on top of the gel. Electrophoresis was performed for $2.5 \mathrm{~h}$ with $5 \mathrm{~mA}$ at $20^{\circ} \mathrm{C}$. The gels were washed in $10 \%$ acetic acid during $1 \mathrm{~h}$ and subsequently washed repeatedly in $\mathrm{H}_{2} \mathrm{O}$. The gels were analyzed spectrophotometrically at $260 \mathrm{~nm}$. Ribosomal RNA of E. coli which was purchased from P.L. Biochem. Inc. was used as $\bar{a}$ reference.

Statistical evaluation. Significance levels for protection were determined by the Fisher exact test, as described by Bradley (3).

RESLLIS

The induction of LPS-specific antibodies and protection by RNA from ribosomal preparations.

In order to determine whether contaminating 0-antigens contri- 
Table 1. LPS-SPECIF IC ANTIBODIES AND PROTECIION INDUCED BY RNA ISOLATED FROM CRUDE CUR PURIFIED RIBOSOMAL PREPARATIONS OF P. AERUGINOSA.

\begin{tabular}{|c|c|c|c|}
\hline \multicolumn{2}{|c|}{ RNA prepn. ${ }^{a}$} & \multirow{2}{*}{$\begin{array}{l}\log _{2} \text { titer of } \\
\text { antibodies to LPS }\end{array}$} & \multirow{2}{*}{$\begin{array}{c}\text { Survival } \\
\left(\begin{array}{c}0 \\
\text { (o) }\end{array}\right)\end{array}$} \\
\hline $\begin{array}{l}\text { Source } \\
\text { of RNA }\end{array}$ & $\begin{array}{l}\text { Dose of } \\
\text { RNA }(\mu g)\end{array}$ & & \\
\hline
\end{tabular}

Crude ribo-

somal prepn.

$\begin{array}{lrr}5 & 8.8 & 90 \\ 1 & 5.5 & 90 \\ 0.2 & 2.0 & 10 \\ 0.04 & 1.7 & 0\end{array}$

Purified ribo-

somal prepn. 5

$2.10 \quad 85$

$11.5 \quad 20$

$0.2 \quad 0.8 \quad 10$

$0.04 \quad 0.7 \quad 5$

Buffer

0.7

0

A RNA was mixed with the adjuvant DDA before injection. Contrals were injected with buffer and DDA.

b LPS-specific antibodies were determined in the pooled sera of five mice by an ELISA. Each number represents the mean value of determinations of two pools of sera.

C Croups of 20 mice were injected as indicated and challenged six days later with a lethal dose of the homologous P. aeruqinosa strain. 
Table 2. DETECIION OF LPS COMTAMINATION WITH THE LIMULUS TEST.

\begin{tabular}{|c|c|c|c|}
\hline Sample ${ }^{a}$ & $\begin{array}{l}\text { Lowest sample } \\
\text { dose (ng) } \\
\text { positive in } \\
\text { Limulus test }\end{array}$ & $\begin{array}{l}\text { Highest sample } \\
\text { dose ( } \mathrm{ng} \text { ) } \\
\text { negative in b } \\
\text { Limulus test }\end{array}$ & $\begin{array}{l}\text { OPS }(X)^{c} \\
\text { in sample }\end{array}$ \\
\hline Endatoxin standard & 0.1 & 0.05 & \\
\hline LPS of P.aeruginosa & 20 & 15 & \\
\hline Puriffled ribosomes & $5 \times 10^{3}$ & $2.5 \times 10^{3}$ & $0.3 \%<x<0.8 \%$ \\
\hline $\begin{array}{l}\text { RNA isolated from } \\
\text { purified ribosomes }\end{array}$ & & $5 \times 10^{6}$ & $x<0.0004 \%$ \\
\hline $\begin{array}{l}\text { Endotoxin standard } \\
\text { plus } 5 \mathrm{mg} \text { RNA }\end{array}$ & 0.1 & 0.05 & \\
\hline
\end{tabular}

All sample preparations except for the endotoxin standard were derived from P. aeruginosa strain 5321. Endotoxin standard, a preparation which was supplied with the Limulus test kit, was prepared from E. coli.

b Craded doses of each sample were examined for the presence of LPS with the 1. Anulus tost. The lowest sample dose in which LPS was detected with the Limulus test (positive in Limulus test,) and the highest sample dose in which no LPS could be detected (negative in Limulus test) are presented.

$c$ The percentage of contaminating LPS of $P$. aeruginosa in $r$ ibosonal preparations was calculated considering that the highest negative sample dose contained less than 20 ng of LPS while the lowest positive sample dose contalned more than $15 \mathrm{ng}$ of LPS. 
buted to the protective activity of RNA from ribosomal preparations, the ability of these preparations to induce LPS-specific antibodies was examined. RNA isolated from a crude ribosomal preparation induced significant titers of LPS-specific antibodies (Table 1). However, RNA isolated from the purified ribosomes gave rise to very low anti-LPS titers, which could not account for the protective activity of this RNA preparation.

Detection of LPS contamination by means of the Limulus test.

The Limulus test appeared to be less sensitive for LPS from P. aeruginosa than for the endotoxin standard from E. coli which was supplied with the Limulus test kit. Twenty ng of LPS from $P$. aeruginosa strain 5321 was required to obtain a positive result while $0.1 \mathrm{ng}$ of endotoxin standard was sufficient for gel formation (Table 2). LPS was detected in $5 \mu \mathrm{g}$ of the purified ribosomal preparation. The amount of LPS in this $\mathrm{r}$ ibosomal preparation was estimated to lie between 0.3 and $0.8^{\circ}(\mathrm{w} / \mathrm{w})$. Since no L.PS could be detected in $5 \mathrm{mg}$ of RNA isolated from the purified ribosomes, this preparation was estimated to contain less than $0.0004 \%$ LPS. A control experiment in which $5 \mathrm{mg}$ of RNA was added to different concentrations of the endotoxin standard demonstrated that RNA did not interfere with the reaction between LPS and the Limulus reagent.

The protective activity of RNA and LPS in $\mathrm{C}_{3} \mathrm{H} / \mathrm{HeJ}$ and in $\mathrm{C}_{3} \mathrm{Heb} / \mathrm{FeJ}$ mice.

$\mathrm{C}_{3} \mathrm{H} / \mathrm{HeJ}$ mice are known to be insensitive to the mitogenic and immunogenic properties of LPS in comparison with $\left.C_{3} \mathrm{Heb} / \mathrm{Fe}\right]$ mice which are of the same genetic background (25). A possible contribution of LPS to the protective activity of RNA isolated from purifind ribosomes was tested in these two strains of mice.

$\mathrm{C}_{3} \mathrm{Heb} / \mathrm{FeJ}$ mice were protected by the injection of a lower dose of LPS than $\mathrm{C}_{3} \mathrm{H} / \mathrm{HeJ}$ mice (Table 3 ). In contrast, similar survival percentages of $\mathrm{C}_{3} \mathrm{H} / \mathrm{HeJ}$ mice and $\mathrm{C}_{3} \mathrm{Heb} / \mathrm{FeJ}$ mice were obtained when these mice had been treated with the ribosomal vaccine or with RNA isolated from the purified ribosomes. The titers of antibodies to LPS induced by each of the vaccines were higher in $C_{3} \mathrm{Heb} / \mathrm{FeJ}$ mice than in $\mathrm{C}_{3} \mathrm{H} / \mathrm{HeJ}$ mice. However, in the control sera the anti-LPS titers also were higher in the former strain of mice than in the latter.

Protective activity of ribosomal vaccines isolated from a LPSdefective mutant strain of $P$. aeruginosa, PAC 605 , and its parent strain PAC 1R.

LPS, purified ribosomes, and RNA isolated from these ribosomes were prepared from a LPS-defective mutant strain of $P$. aeruginosa, PAC 605 and from the parent strain of this mutant, PAC IR. The protective activity of these preparations was tested in Swiss 
Table 3. PROTECTIVE ACTIVITY OF RNA AND LPS IN $\mathrm{C}_{3} \mathrm{H} / \mathrm{HeJ}$ ANO $\mathrm{C}_{3} \mathrm{Heb} / \mathrm{FeJ}$ MOUSE STRAINS.

\begin{tabular}{|c|c|c|c|c|c|}
\hline \multicolumn{2}{|c|}{ Prepn. } & \multicolumn{2}{|c|}{ Survival $\left(y^{\prime}\right)$ b } & \multicolumn{2}{|c|}{$\begin{array}{l}\log _{2} \text { tites of } \\
\text { antibadies to LPS }\end{array}$} \\
\hline Type & Doge ( $(49)$ & $\mathrm{C}_{3} \mathrm{H} / \mathrm{HeJ}$ & $\mathrm{C}_{3} \mathrm{Heb} / \mathrm{FeJ}$ & $\mathrm{C}_{3} \mathrm{H} / \mathrm{HeJ}$ & $\mathrm{C}_{3} \mathrm{Heb} / \mathrm{FeJ}$ \\
\hline \multirow[t]{2}{*}{ LPS } & 1 & 43 & $90^{d}$ & 2.6 & 6.1 \\
\hline & 0.1 & 0 & $67^{d}$ & 2.6 & 5.3 \\
\hline \multicolumn{6}{|l|}{ Purified } \\
\hline ribosomes & 50 & 97 & 93 & 2.8 & 5.6 \\
\hline plus DDA & 5 & 77 & 73 & 2.4 & 2.9 \\
\hline \multicolumn{6}{|l|}{ RNA firom } \\
\hline $\begin{array}{l}\text { purified } \\
\text { ribosomes }\end{array}$ & 50 & 97 & 83 & 1.8 & 2.9 \\
\hline plus DDA & 5 & 43 & 30 & 1.1 & 2.8 \\
\hline Buffer & & 0 & 0 & 1.3 & 2.3 \\
\hline \multirow{2}{*}{\multicolumn{2}{|c|}{$\begin{array}{l}\text { Buffer } \\
\text { plus DDA }\end{array}$}} & & & & \\
\hline & & 15 & 0 & 1.5 & 2.5 \\
\hline
\end{tabular}

All preparations ware isolated from P. aeruginosa strain 5321 .

b Groups of 30 mice of each inbred strain were vaccinated as indicaled and challanged six days later with the homologous $P$. aeruginosa strain 5321 .

$c$ The titer of antibodies to LPS was determined in pooled serum of five mice by the ELISA. Each number represents the mean value of determinations on 4 pools of sera.

d The P-values were $<0.01$ with respect to the percentages of survival of $\mathrm{C}_{3}$ H/HeJ mice which wre vacoinated with LPS. 
outbred mice using $P$. aeruginosa strain 5321 as challenge organism. Ten $\mu 9$ of defective LPS from PAC 605 was required to induce $50^{\circ}$ survival whereas as 1 itt 1 e as $10 \mathrm{ng}$ of $L P S$ from PAC IR was sufficient to protect the same percentage of mice (Talie 4). Much higher titers of LPS-specific antibodies were induced by the LPS from PAC IR than by the LPS from PAC 605. Likewise, higher percentages of survival and higher titers of antibodies to LPS were induced by the purified ribosomal vaccine from PAC IR than by the purified ribosomes from PAC 605. No LPS-specific antibodies were induced by RNA isolated from the purified ribosomes of either PAC IR or PAC 605, and similar percentages of survival were induced by these two RNA preparations. The $P$ values for the protective activity of $25 \mu \mathrm{g}$ of RNA from PAC $1 R$ and of 5 and $25 \mu \mathrm{g}$ of RNA from PAC 605 were $<0.01$ with respect to the corresponding controls.

Non-specific protection induced by RNA isolated from different microorganisms.

The protective activity of commercially available RNA preparations from ribosomes of E.coli (MRE600), ribosomes of 5 . cerevisiae, and from the phage $\mathrm{MS2}$ were compared with the protective activity of ribosomal RNA from two different serotypes of $P$. aeruginosa prepared in our laboratory. The rapid induction and the non-serotype-specificity were considered to be characteristic properties of the ribosomal RNA from $P$. aeruginosa (13).

Therefore the protective activity of the commercially avalable RNA preparations was tested as early as two days after injection of the RNA, and the challenge injections were given with two serotypes of $P$. aeruginosa and with $E$. coli.

RNA from ribosomes of $P$. aeruqinosa protected mice not only

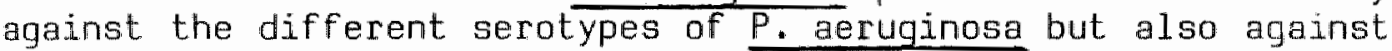
a challenge with E. coli (Table 5). Ribosomal RNA from E. coli or from 5 . cerevisiae protected mice to the same extent as ribosomal RNA from $P$. aeruginosa against $P$. aeruginosa or $E$. coli two and six days after injection. In contrast, $5 \mu \mathrm{g}$ RNA from the phage MS2 had no protective activity, neither 2 nor 6 days after injection.

\section{Polyacrylamide gel electrophoresis of RNA.}

The RNA preparations used in the experiments presented in Table 5 were analyzed by polyacrylamide gel electrophoresis to see whether the protective activity of the RNA preparations could be correlated with the integrity and the size of the RNA nolocules.

Fig. 1 demonstrates that intact 235 and 165 RNA was present in the RNA preparations isolated from the procaryotic ribosomes of P. aeruqinasa, while 185 and 285 RNA peaks were seen in the RNA preparation from the eucaryotic ribosomes of S. cerevisiae. The non-protective RNA from phage MS2 contained undegraded, high molecular weight RNA. In contrast, the protective ribosomal RNA from E. coli (MRE600) appeared to be extensively degraded. 
Table 4. PROTECTION AND ANTIBODIES TO LPS INOUCED BY LPS AND RIBOSOMAL PREPARATIONS DERIVED FROM A LPS-DEFECTIVE MUTANT STRAIN OF P. AERUCINUSA PAC 605 AND ITS PARENT STRAIN PAC IR.

\begin{tabular}{|c|c|c|c|c|c|}
\hline \multicolumn{2}{|c|}{ Prepn. a } & \multicolumn{2}{|c|}{$\begin{array}{l}\text { Survival (\%) induced } \\
\text { by vaccines from }\end{array}$} & \multicolumn{2}{|c|}{$\begin{array}{l}\log _{2} \text { titer }{ }^{b} \text { of anti- } \\
\text { bodies to LPS induced } \\
\text { by vaccines from }\end{array}$} \\
\hline Type & Dose ( $\mu g)$ & $P A C \quad I R$ & PAC 605 & PAC IR & PAC 605 \\
\hline $\begin{array}{l}\text { LPS } \\
\text { (or defective } \\
\text { LPS) }\end{array}$ & $\begin{array}{l}10 \\
1 \\
0.1 \\
0.01 \\
0.001\end{array}$ & $\begin{array}{l}90 \\
85 \\
55 \\
20\end{array}$ & $\begin{array}{r}50 \\
15 \\
0 \\
10 \\
5\end{array}$ & $\begin{array}{r}10.5 \\
9.0 \\
7.2 \\
4.6\end{array}$ & $\begin{array}{l}4.9 \\
3.3 \\
1.0 \\
2.1 \\
0.5\end{array}$ \\
\hline $\begin{array}{l}\text { Purified } \\
\text { ribosomes } \\
\text { plus DDA }\end{array}$ & $\begin{array}{r}25 \\
5 \\
1\end{array}$ & $\begin{array}{l}95 \\
55 \\
21\end{array}$ & $\begin{array}{l}75 \\
20 \\
15\end{array}$ & $\begin{array}{l}7.3 \\
4.7 \\
2.1\end{array}$ & $\begin{array}{l}4.1 \\
0.9 \\
0.5\end{array}$ \\
\hline RNA plus DDA & $\begin{array}{r}25 \\
5 \\
1\end{array}$ & $\begin{array}{r}33 \\
20 \\
3\end{array}$ & $\begin{array}{l}55 \\
40 \\
17\end{array}$ & $\begin{array}{l}1.5 \\
0.9 \\
0.9\end{array}$ & $\begin{array}{l}1.1 \\
0.1 \\
1.0\end{array}$ \\
\hline Buffer & & 0 & 0 & 1.1 & 0.8 \\
\hline Buffer + DDA & & 3 & 13 & 0.0 & 0.0 \\
\hline
\end{tabular}

Swiss mice were injected with vaccines prepared from $P$. aeruginosa PAC IR and challenged six days later with P. aeruginosa strain 5321 which is of the same seratype as PAC IR. Croups of 20 mice were used for each dose of LPS or purified ribosomes, while groups of 30 mice were injected with the RNA preparations.

b Antibodies to LPS (serotype 3) were determined in pooled sera of 5 mice by the ELISA. Each number represents the mean value of determinations on 2 pools of sera. 


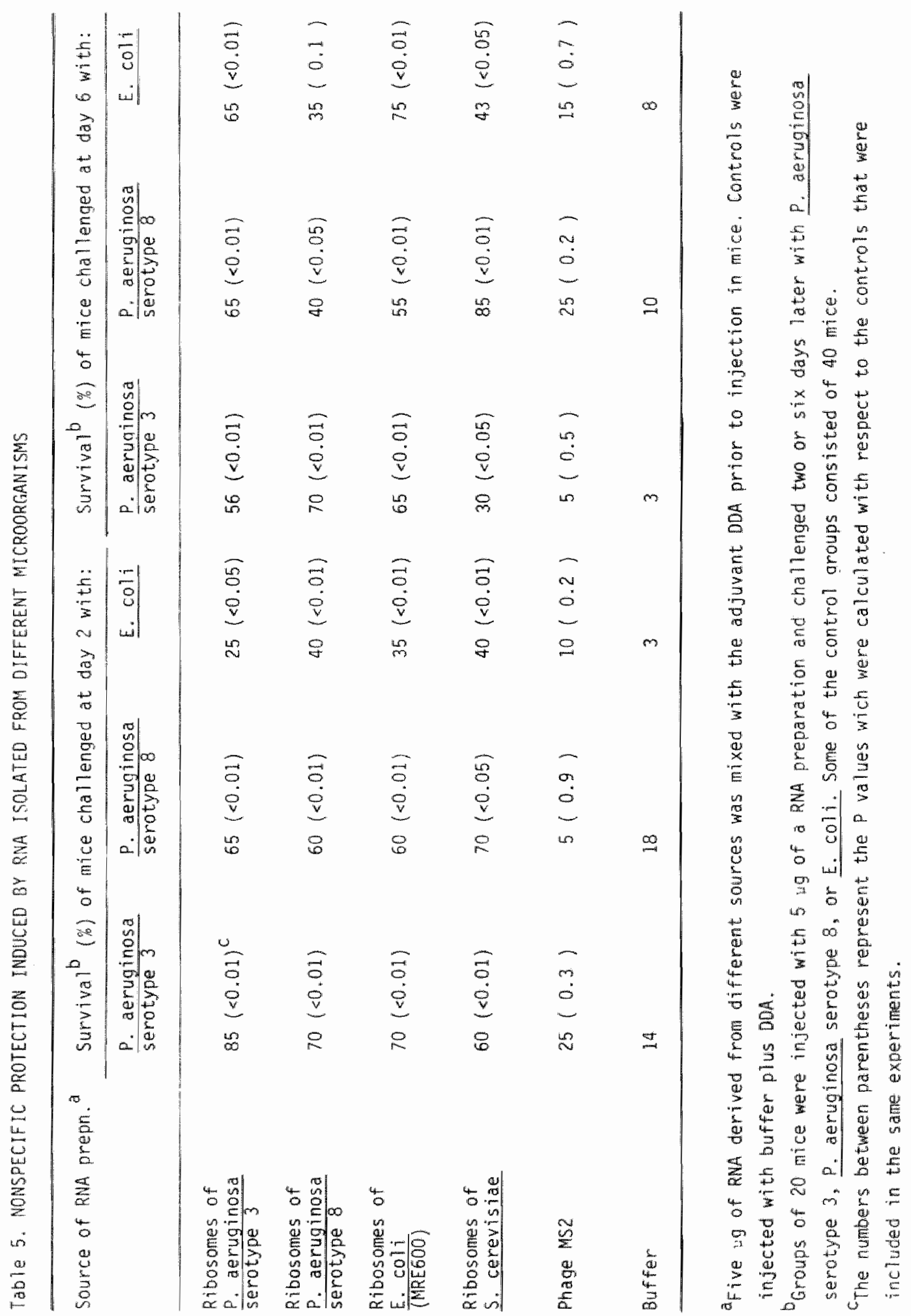




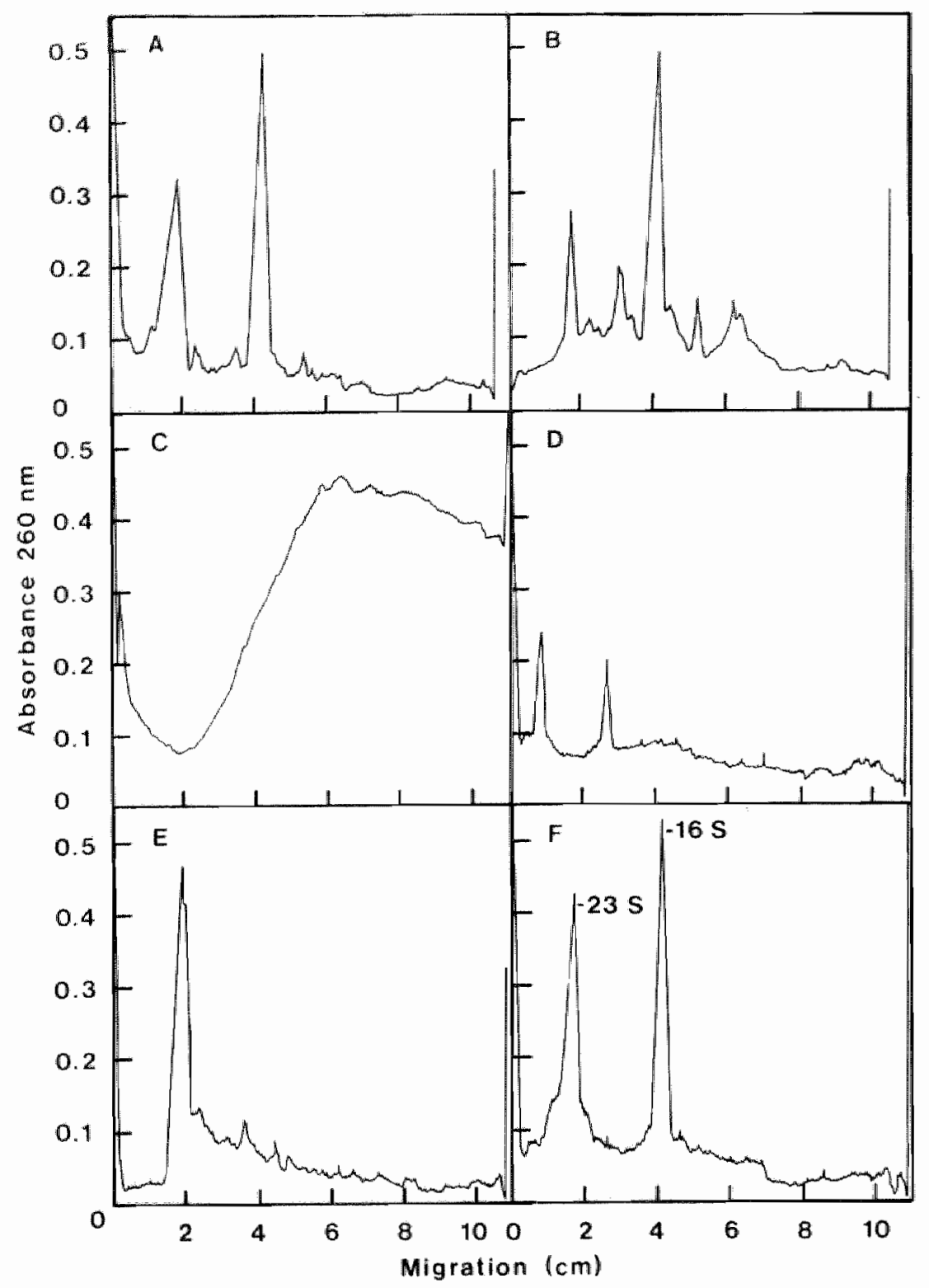

Fig. 1 Polyacrylamide gel electrophoresis of RNA isolated from different microorganisms. (A) RNA from purified ribosomes of P. aeruginosa serotype 3 (strain 5321); (B) RNA from purified ribosomes of $P$. aeruginosa serotype 8 (strain 5309); (C) RNA from ribosomes of $E_{*}$ cali (MRE600); (D) RNA from ribosomes of 5 . cerevisiae; (E) RNA from phage MS2; (F) RNA from ribosomes of E. coli (R-13). 
The discussion concerning the nature of the protective components in ribosomal vaccines has been focused on the question whether contaminating cell envelope antigens in the ribosomal preparations are totally, in part, or not at all responsible for the protective activity of these vaccines.

Although the ribosomal vaccine of $P$. aeruginosa, which was prepared in our laboratory, was contaminated with LPS, experimental results suggested that RNA did contribute to the protective activity of this vaccine by the induction of early and nonspecific protection $(12,13)$. In the present paper several experiments are described which confirm that the RNA is responsible for particular protective activities of the ribosomal vaccine.

RNA isolated from purified ribosomes gave rise to very low anti-LPS antibody titers which could not account for the protective activity of this preparation. With the Limulus test it was found that the RNA preparation contained less than 0.0004\% of LPS. From data of previous experiments it could be calculated that at least $5 \mathrm{ng}$ of LPS was required to induce the same percentages of survival which were induced by $5 \mu \mathrm{g}$ RNA (13).

$\mathrm{C}_{3} \mathrm{H} / \mathrm{HeJ}$ mice are low responders to LPS in comparison with strains with the same genetic background, i.e. $\mathrm{C}_{3} \mathrm{Heb} / \mathrm{FeJ}$. Only a weak antibody response was induced by LPS in $\mathrm{C}_{3} \mathrm{H} / \mathrm{HeJ}$ mice, while this strain of mice did not support mitogenic responses to LPS (25).

The protective activity of LPS and the anti-LPS antibody titer were lower in $C_{3} \mathrm{H} / \mathrm{HeJ}$ mice than in $C_{3} \mathrm{Heb} / \mathrm{FeJ}$ mice. In contrast, the protective activity of RNA isolated from purified ribosomes was equal in both strains of mice. The ribosomal vaccine also induced equal protection in both strains of mice. This was an unexpected result since previous experiments suggested that both RNA and LPS contributed to the protective activity of the ribosomal vaccine (13).

Not only the titers of antibodies to LPS in vaccinated $\mathrm{C}_{3} \mathrm{Heb} / \mathrm{FeJ}$ mice were higher than those in $\mathrm{C}_{3} \mathrm{H} / \mathrm{HeJ}$ mice, but also the titers in the non-vaccinated control groups of the former strain were higher than those in the latter strain of mice. In Swiss outbred mice only titers of LPS-specific antibodies $>5$ were associated with protection (12). These anti-LPS titers were only found in sera of $C_{3} \mathrm{Heb} / \mathrm{FeJ}$ mice. The anti-LPS titers and the protective activity of LPS in $\left.\mathrm{C}_{3} \mathrm{Heb} / \mathrm{Fe}\right]$ mice were lower than those which were usually obtained in Swiss outbred mice (12, Table 4). This might. explain why no contribution of LPS to the protective activity of the ribosomal vaccine was observed in $\mathrm{C}_{3} \mathrm{Heb} / \mathrm{FeJ}$ mice.

Defective LPS from a mutant strain of P. aeruginosa, PAC 605, 
contained Lipid $A$, and some core polysaccharides but lacked the neutral sugars of the LPS care as well as the 0 antigenic side chains (18). Protection by defective LPS was only abtained at a dose of $10 \mathrm{Hg}$, while $10 \mathrm{ng}$ of intact LPS from PAC IR, the parent strain of PAC 605, was sufficient to protect mice against $P$. aeruginosa. The ribosomal vaccine from $P A C$ IR also induced higher percentages of survival and higher anti-LPS titers than the ribosomal vaccine from the mutant strain PAC 605. In contrast, similar protective activity was obtained with the RNA preparations from ribosomes of PAC IR and PAC 605. No antibodies to LPS were induced by these RNA preparations. Although the protective activity of both of these RNA preparations was lower than the protective activity of RNA isolated from the P. aeruginosa strain 5321, repeated experiments confirmed that the RNA preparations of PAC IR and PAC 605 did have protective activity. LPS apparently did not contribute to the protective activity of the RNA preparations.

The mitogenic and the adjuvant activity of LPS have been ascribed to the 1 ipid A part of the molecule (5). The finding that the defective LPS of PAC 605, consisting of lipid A and some core polysaccharides, did not induce protection, confirmed our opinion that the non-specific protection by RNA was not due to the mitogenic activities of contaminating (fragments of) LPS. The protection and the slightly increased anti-LPS titer which were induced by $10 \mu \mathrm{g}$ of LPS from PAC 605, might be due to traces of 0 antigenic material in this preparation. LPS of PAC 605 normally contains less than 1 percent of the 0 antigenic content of the wild type (P.M. Meadow, personal communication).

The protective activity of ribosomal RNA appeared to be nonspecific. RNA preparations from ribosomal vaccines of two strains of P. aeruginosa, and ribosomal RNA from E. coli (MRE600) and S. cerevisiae protected mice against a lethal challenge with $\bar{P}$. aeruginosa or with E. coli. No LPS is present in the cell wall of S. cerevisiae. The results thus far strongly suggest that the protective activity of ribosomal RNA preparations is not due to contaminating LPS.

Dur results suggested that the ability to induce early, nonspecific protection is a property of any ribosomal. RNA, whether it was isolated from procaryotic or eucaryotic cells. Several authors reported the induction of nonspecific protection by ribosomes or ribosomal RNA $(2,6,20)$. However, the conditions under which protection by RNA was achieved varied with respect to the use of an adjuvant and the duration of the protection. Moreover, these reports were each concerned with protection against intracellular microorganisms, except for the early protection induced by mycobacterial ribosomes against Klebsiella pneumoniae (6). Weinstein et a1. (26) reported that early nonspecific resistance against several extracellular microorganisms could be induced by a synthetic polyribonucleotide, i.e. poly (I.C), without adjuvant. 
Further experiments are required to find out whether the early nonspecific protection induced by ribosomal RNA which is mixed with the adjuvant DDA is related to any of the above mentioned protective activities of ribosomal or synthetic RNA's.

The finding that RNA from the phage MS2 had no protective activity suggested that the protective activity of ribosomal RNA from procaryotic or eucaryotic cells might be due to a structure of the RNA molecules which is not present in the RNA of phage MS2. The lack of protection by MS2 RNA was not due to degradation of this preparation. Polyacrylamide gel electrophoresis demonstrated that the non-protective MS2 RNA was intact, while the ribosomal RNA of E.coli (MRE600) had retained its protective activity although it was extensively degraded.

Since ribosomal RNA's are modified by methylation while the RNA of MS2 is not, this difference in the structure of RNA might be connected with the different protective activities of these two types of RNA.

Youmans and Youmans (28) have reported that the protective activity of their mycobacterial RNA preparations was correlated with the integrity of the 20S-235 RNA molecules in the preparations. In contrast, our experimental results suggested, however, that degraded ribosomal RNA retained its protective activity. This difference might be due to the use of DDA which possibly resulted in larger RNA complexes.

\section{ACKNOWLEDGEMENTS}

We are indebted to P.M. Meadow (Dept. Biochemistry, University College of London, London) for her kind gift of the P. aeruginosa strains PAC $I R$ and PAC 605.

We thank J. van Duin (Biochemical Laboratory, State University of Leiden, The Netherlands) for valuable advice on the polyacrylamide gel electrophoresis of RNA.

The authors thank J.M.N. Willers (Department of Immunology, Laboratory of Microbiology, State University of Utrecht, The Netherlands) for his continuous interest, valuable contribution and advice concerning this work.

B.I. Davies (Dept. Bacteriology, De Wever Hospital, Heerlen, The Netherlands) is gratefully acknowledged for carefully reading the manuscript . 
1. Angerman, C.R. and T.K. Eisenstein. Comparative efficacy and toxicity of a ribosomal vaccine, acetone-killed cells, lipopolysaccharide, and a live cell vaccine prepared from Salmonella typhimurium. Infect. Immun. 19: 575-582.

2. Araujo, F.G. and J.S. Remington. 1974. Protection against Toxoplasma gondi in mice immunized with toxoplasma ce 1 fractions, RNA and synthetic polyribonucleotides. Immunology 27: $711-721$.

3. Bradly, J.V. 1968. Distribution free statistical tests, P. 216-226. Prentice Hal1 Inc , Englewood Cliffs, N.J.

4. Chester, I.R. and P.M. Meadow. 1975. Heterogeneity of the lipopolysaccharide from Pseudomonas aeruginosa. Eur. J. Biochem. 58: 273-282.

5. Chiller, J.M., B.J. Skidmore, D.C. Morrison and W.O. Weigle. 1973. Relationship of the structure of bacterial lipopolysaccharides to its function in mitogenesis and adjuvanticity. Proc. Nat. Acad. Sci. 70: 2129-2133.

6. Coppel, S. and G.P. Youmans. 1969. Specificity of acquired resistance produced by immunization with mycobacterial cells and mycobacterial fractions. J. Bacteriol. 97: 114-120.

7. Eisenstein, T.K. Evidence for 0 antigens as the antigenic determinants in "ribosomal" vaccines prepared from Salmonella. Infect. Immun. 12: 364-377.

8. Eisenstein, T.K. 1978. Ribosomal vaccines: a review, p. 211222. In A. Voller and H. Friedman (ed.), New Trends and developments in vaccines. MTP Press Limited. St. Leonard Gate.

9. Field, L.H., C.D., Parker, C.R. Manclark and L.J. Berry. 1979. Evaluation of a ribosomal vaccine against pertussis. Infect. Immun. 24: 346-351.

10. Calanos, C., 0. Luderitz and 0. Westphal. 1969. A new method for the extraction of R. lipopolysaccharides. Eur. J. Biochem. 9: $245-249$.

11. Gonggrijp, R., W.J.H.A. Mullers, P.J.M.R. Lemmens and C.P.A. van Boven. 1980. Ribonuclease sensitive ribosomal vaccine of Pseudomonas aeruginosa. Infect. Immun. 27: 204-210.

12. Gonggrijp, R., M.P.W. Volleberg, P.J.M.R. Lemmens and C.P.A. van Boven. 1981. Evidence for the presence of lipopolysaccaride in a ribonuclease sensitive ribosomal vaccine of Pseudomonas aeruginosa. Infect. Immun. 31: 896-905.

13. Gonggrijp, R., W.J.H.A. Mullers and C.P.A. van Boven. 1981. Serotype-nonspecific protection induced by ribonucleic acid isolated from the ribosomal vaccine of Pseudomonas aeruginosa. Infect. Immun. 33:

14. Hartree, E.F. 1972. Determination of protein: a modification of the Lowry method that gives a linear photometric response. Anal. Biochem. 48: 422-427. 
15. Herbert, D., P.H. Phipps and R.E. Strange. 1971. Chemical analysis of microbial cells, $p .308-328$. In J.R. Norris and D.W. Ribbons (ed.); Methods in Microbiology, vol. 5B. Academic Press Inc., London.

16. Horton, D. and G. Rodemeyer. 1977. Analytical characterization of lipopolysaccharide antigens from seven strains of Pseudomonas aeruginosa. Carbohydr. Res. 55. 35-47.

17. Kabat, E.A. and M.M. Mayer. 1961. Experimental immunochemistry, 2nd ed., p. 833. Charles C. Thomas Publishers, Springfield, Ill.

18. Koval, S.F. and P.M. Meadow. 1977. The isolation and characterization of lipopolysaccharide-defective mutants of Pseudomonas aeruginosa PAC 1. J. Gen. Microbiol. 98: 387-398.

19. Lin, J.H. and L.J. Berry. 1978. the use of strain LT2-M1 in identifying the protective antigens in a Salmonella typhimurium derived ribosomal vaccine. J. Reticuloendothel. Soc. 23: $135-143$.

20. Medina, S., S.J. Vas and H.G. Robson. 1975. Effect of nonspecific stimulation of the defense mechanisms of inbred mice. J. Immunol. 114: 1720-1725.

21. Misfeldt, M.L. and W. Johnson. 1978. Identification of protective cell surface proteins in ribosomal fractions from Salmonella typhimurium. Infect. Immun. 24: 808-816.

22. Pier, G.B., H.F. Sidberry and J.C. Sadoff. 1978. Protective immunity induced in mice by immunization with high-molecularweight polysaccharide from Pseudomonas aeruginosa. Infect. Immun. 22: 919-925.

23. Riottot, M.M., J.M. Fournier and H. Jouin. 1981. Direct evidence for the invoivement of capsular polysaccharide in the immunoprotective activity of Klebsiella pneumoniae ribosonal preparations. Infect. Immun. 31: 71-77.

24. Schalla, W.0. and $W$. Johnson. 1975. Immunogenicity of ribosomal vaccines isolated from group A, type 14 Streptacoccus pyogenes. Infect. Immun. 11: 1195-1202.

25. Watson, J. and R. Riblet. 1974. Genetic control of responses to bacterial lipopolysaccharides in mice. I. Evidence for a single gene that influences mitogenic and immunogenic responses to lipopolysaccharides. J. Exp. Med. 140: 1147-1161.

26. Weinstein, M.J., J.A. Waitz and P.E. Came. 1970. Induction of resistance to bacterial infections of mice with poly I : poly C. Nature 226: 170 .

27. Weissbach, A, and J. Hurwitz, 1959. The formation of 2-keto3-deoxyheptonic acid in extracts of Escherichie coli B. I. Identification. J. Biol. Chem. 234: 705-709.

28. Youmans, A.S. and G.P. Youmans. 1973. The relationship between sedimentation value and immunogenic activity of mycobacterial ribonucleic acid. J. Immunol. 110: 581-586. 
29. Youmans, A.S. and G.P. Youmans. 1975. Mycobacterial extracts and immunity to tuberculosis, P. 399-410. In E. Neter and F. Milgrom (eds.), The immune system and infectious diseases. Karger, Basel. 


\section{Chapter 8}

\section{Studies on the mechanism of nonspecific protection induced by ribosomal ribonucleic acid of Pseudomonas aeruginosa and the adjuvant dimethyldioctade- cylammonium bromide.}

\section{SUMMARY}

Five microgram of a ribosomal vaccine of Pseudomonas aeruginosa or of ribonucleic acid (RNA) isolated from this preparation induced nonspecific protection in mice as soon as one day after intraperitoneal injection. The ribosomal vaccine and RNA had to be combined with 150 microgram of the adjuvant dimethyldioctadecylammonium bromide (DDA) in order to be protective.

The lethal dose of $P$. aeruginosa for 50 percent of mice $\left(L_{50}\right)$ increased after intraperitoneal injection of DDA alone, but addition of RNA to DDA resulted in a still higher $L_{50}$. Although intraperitoneal injection of RNA + DDA induced a much higher, local resistance against intraperitoneally injected $P$. aeruginosa than subcutaneous or intravenous injection, indications were found that RNA + DDA, but not DDA alone, slightly increased the systemic resistance of the host. Intraperitoneal injected DDA attracted significant numbers of peritoneal cells, both macrophages (MAs) and polymorphonuclear leucocytes (PMNLs). Addition of RNA to DDA resulted in higher numbers of peritoneal cells, in particular PMNLs. No clear quantitative correlation was found between the numbers of peritoneal cells in treated mice and the LD 50 of $P$. aeruginosa for these mice. In vivo phagocytosis experiments with opsonized $P$. aeruginosa showed that an increase in the number of peritoneal cells was associated with an increase in the percentage of injected bacteria that was ingested. In addition, a lower bacteria to cell ratio resulted in a lower bacterial load of the MAs and probably in a better killing of the ingested bacteria. No indications were found for an enthanced phagocytic or killing activity of MAs from DDA or RNA + DDA treated mice. No interferon activity could be detected in the peritoneal fluid of RNA + DDA treated mice.

In conclusion the results suggested that the nonspecific protection induced by RNA + DDA was in part due to the attraction of 
phagocytic cells and in part to an yet undefined effect on the systemic resistance of the hast.

\section{INTRODUCTION}

Previous studies (10) have demonstrated that mice could be protected against Pseudomonas aeruginosa after a single intraperitoneal injection with 5 micrograms of a ribosamal vaccine combined with 150 micrograms of the adjuvant dimethyldioctadecylammonium bromide (DDA). Analysis of the protective components in the ribosomal waccine of $P$. aeruginosa revealed, that this vaccine was a multicomponent vaccine in which both a contaminating ce 11 surface antigen, i.e. Lipopolysaccharide (LPS), and ribosomal ribonucleic acid (RNA) contributed to the protective activity. Traces of contaminating LPS in the ribosomal preparation induced anti-LPS antibodies which were responsible for the serotype specific immunity (9).

Purified ribosomal. RNA mixed with DDA appeared to induce nonspecific protection against different $P$. aeruginosa serotypes and against Escherichia coli. In addition, RNA + DDA functioned as an adjuvant for the induction of antibodies by the contaminating LPS (10). The ribosomal vaccine, Iike the purified PNA, induced nonspecific protection. However, higher percentages of survival were reached after homologous than after heterologous challenge since the L.PS specific antibodies contributed only to the elimination of the homologous $P$. aeruginosa bacteria. Cooperation between the nonspecific protection induced by RNA + DDA and the specific immunity induced by LPS was demonstrated by the finding that the ribosomal vaccine induced higher percentages of survival at certain concentrations of anti-LPS antibodies than purified LPS (9, 10).

Since the contribution(s) of ribosomal components to the protective activity of the ribosomal vaccine were considered to be of particular interest, this report is focussed on the protective activity of RNA + DDA. The mechanism by which nonspecific protection was induced by RNA + DDA was studied first since these studies might also yield information about the mechanism by which RNA exerted its adjuvant function.

Previous experiments have demonstrated that the nonspecific protection by RNA + DDA was induced as soon as one day after injection, while it lasted not much longer than 6 days. Therefore it has been suggested that RNA + DDA might enhance the phagocytic activity of the host (10). The present paper describes studies on the events in the peritoneal cavity of the host after injection of RNA + DDA. The relevance of these events for the nonspecific protection is discussed. 
Bacteria. P. aeruginosa serotype 3 (strain RIV 76-5321) (B) was used throughout these studies for the preparation of vaccines and as the challenging organism.

Animals. Dutbred male and female $C p b$ SE Swiss mice (body weight 18 to $20 \mathrm{~g}$ ) were purchased from TNO, Central Institute for the Breeding of Laboratory Animals, Zeist, The Netherlands.

Bacterial preparations. The ribosomal vaccine (fraction II) was obtained from a crude ribosomal preparation by molecular sieve chromatography as described previously (8). Four batches were pooled and further used as the ribosomal vaccine.

The amount of RNA was estimated by the orcinol method of Herbert et al. (12) using yeast RNA (Boehringer Mannheim Corp., Mannheim, West Germany) as the standard. Protein was determined by the Fol in method modified by Hartree (11) with bovine serum albumin (Sigma Chemical Co., St. Louis, Mo.) as the standard. LPS was estimated by the determination of 2-keto-3-deoxyoctonate (KDO) after hydrolyzing the sample with $0.014 \mathrm{~N} \mathrm{H}_{2} 5 \mathrm{O}_{4}$ for $20 \mathrm{~min}$ at $100^{\circ} \mathrm{C}$.

KDO was determined by the thiobarbituric acid method of Weissbach and Hurwitz (20) with KDO (Sigma Chemical Co.) as the standard. The amount of LPS was calculated assuming that LPS contains 5\% KDO (13). The ribosomal vaccine contained 63\% RNA and 35\% protein. No LPS was detected in this preparation by determination of KDO. Ribosomal ribonucleic acid (RNA) was extracted from the ribosomal preparation with phenol and sodium dodecyl sulphate and purified as described by Poulson (16). The RNA preparation contained I: protein. LPS was extracted from P. aeruginosa according to the method of Galanos (7) and purified by treatment with deoxyribonuclease, ribonuclease and pronase $E$ as described previously $(9)$. The LPS preparation contained 93\% LPS, 4\% protein and 3\% RNA.

Antibodies to LPS. Antibodies to LPS were determined by an enzyme linked immunosorbent assay (ELISA) as described previously (9). The concentration of antibodies to LPS in a serum is expressed as the $\log _{2}$ of the highest dilution of the serum giving a positive reaction.

Treatment and challenge of mice. Mice were injected intraperitoneally and challenged 6 days later via the same route unless otherwise stated. Preparations containing ribosomes or RNA were 
mixed with an equal volume $(0.1 \mathrm{ml})$ of the adjuvant dimethyldioctadecylammonium bromide (DDA) (Eastman Kodak Co., Rochester, N.Y.), which was sonicated in phosphate buffered saline (PBS) before use ( $1.5 \mathrm{mg}$ DOA per ml PBS). Bacteria which were used for challenge were inoculated from an overnight culture in fresh Irypticase soy brath (BBL Microbiology Systems, Cockeysville, Md.) at a final concentration of $1.5 \times 10^{7}$ bacteria per $\mathrm{ml}$ and grown for 3 hours at $37^{\circ} \mathrm{C}$ under shaking. The preparation of the challenge batch was described previously $(8)$.

The determination of the $50 \%$ lethal dose ( $D_{50}$ ) of $P$. aeruginosa was performed according to the method of Reed and Muench (17). The challenge dose of $P$. aeruginosa strain 5321 contained $6.4 L_{50}$, i.e. $7 \times 10^{7}$ colony forming units (CFU) unless otherwise stated. Deaths, which occurred principally within two days after challenge, were recorded till seven days after challenge.

Collection and differentiation of peritoneal cells. Mice which were injected intraperitoneally with different preparations were killed by cervical dislocation after different periods. Peritoneal cells were harvested $1 \mathrm{~min}$ after injection of $2 \mathrm{ml}$ Hanks balanced salt solution (HBSS) containing 50 units heparin (BDH Chemicals Ltd., Poole, England) in the peritomeal cavity. Cells obtained from 3 mice were pooled for each determination. Pooled cells were centrifuged during $10 \mathrm{~min}$ at $140 \mathrm{~g}$, resuspended in HBSS containing 0.5 units of heparin, and centrifuged again. The number of cells was counted with a henocytometer and the percentage of lymphocytes, macrophages (MAs) and polymorphonuclear leucocytes (PMNLs) was determined by the differentiation of 200 cells in Maycrünwald-Giemsa-stained cytocentrifuge preparations. The mean number of cells per mouse was assumed to be the cell number in 2 $\mathrm{ml}$ of the harvested cell suspension (i.e. the volume which was injected in each peritoneal cavity).

Phagocytosis of $P$. aeruginosa in viva. Mice were injected with $\mathrm{PBS}, \mathrm{DDA}(150 \mu \mathrm{g})$ or RNA $(5 \mu \mathrm{g})+\mathrm{DDA}(150 \mu \mathrm{g})$ and 6 days later they were injected intraperitoneally with $1 \mathrm{ml}$ washed $\mathrm{P}$. aeruginasa bacteria to which $5 \%$ rabbit anti-LPS antibody was added. The rabbit antibody preparation to LPS was prepared as described for rabbit antibodies to fractions I and II (9). In experiments designed to compare the total phagocytic capacities of differentiy pretreated mice the same numbers of $P$. aeruginosa bacteria were injected in each mouse, i.e. $6.6 \times 10^{7}$ (mean number of 3 experiments). In experiments designed to compare the phagocytic capacities of MAs and PMNLs from differently pretreated mice the numbers of injected bacteria were so that the bacteria to cell ratio was approximately $9: 1$.

Mice injected with PBS, DDA, or DDA + RNA were injected with respectively $3 \times 10^{7}, 5.4 \times 10^{7}$, and $8.8 \times 10^{7} \mathrm{P}$. aeruginosa 
bacteria (mean numbers of 4 experiments). The above mentioned numbers of bacteria were determined by microscopic counting with the aid of a counting chamber with a depth of 0.01 min (Marius Instruments, Utrecht, The Netherlands) (micr. number). The numbers of viable bacteria were determined by counting colony forming units (CFU) (viable number). At $t=3.5 \mathrm{~min}$ mice were killed by cervical dislocation and at $t=4 \mathrm{~min} 2 \mathrm{ml}$ ice cold HBSS containing 50 units heparin and $2 \%$ foetal calf serum (FCS) were injected intraperitoneally. The peritoneum was massaged during 30 sec and the cell suspension was withdrawn from the peritoneal cavity and kept on ice. Cell suspensions of 4 mice were pooled for each experiment. Pooled cells were washed 3 times in HBSS containing $0.1^{\Phi}$ gelatin, 10 units heparin and $1 \%$ FCS by centrifuging 5 inin al $140 \mathrm{~g}$ and at $4^{\circ} \mathrm{C}$. The cells were resuspended in the same medium containing $5 \%$ FCS and counted with a hemocytometer. The number of cells per mouse was assumed to be the cell number that was present in $3 \mathrm{ml}$ of the original harvested cell suspension (i.e. the volume of injected bacterial suspension plus the volume of injected medium). Differential counts of 400 cells of each pool were made in May-Grünwald-Giemsa-stained cytocentrifuge preparations and the number of bacteria per MA and per PMNL was counted simultaneously. The number of cell associated viable bacteria was determined after thoroughly mixing $1 \mathrm{ml}$ cell suspension and $10 \mathrm{sec}$ sonicating to disrupt the cells. Calculations were made essentially according to Peterson et al. (15) as follows. The percentage of the injected bacteria (micr. number) that was MA or PMNL associated after $4 \mathrm{~min}$ in vivo phagocytosis (percentage uptake) was calculated from the differential counts with the use of formula 1 :

$$
\begin{aligned}
& { }_{0}^{*} \text { uptake } \\
& \text { in MA }
\end{aligned}=\frac{\begin{array}{l}
\text { mean micr number of bact.per MA } \times \text { number of MAs per } \\
\text { mouse }
\end{array}}{\text { micr.number of bacteria injected per mouse }}
$$

The percentage of viable injected bacteria that was recovered as viable bacteria from the washed peritoneal cells after $4 \mathrm{~min}$ in vivo phagocytosis ( 6 CFU in peritoneal cells) was calculated with the use of formula 2:

$\%$ CFU in number of viable bact. in peritoneal cells $\begin{aligned} & \text { peritoneal } \\ & \text { cells }\end{aligned}=\frac{\text { from } 1 \text { mouse }}{\text { number of viable bacteria injected per mouse }} \times 100$

The percentage of phagocytosed bacteria that was viable in the MAs plus PMNLs after 4 mill in vivo phagocytosis (\% viable of peritoneal cell associated bacteria) was calculated with formula 3 : 
\% viable of peritoneal cell assoc. = micr.number of bact. in MAs and PMNLs $\times 100$ bacteria

in $1 \mathrm{ml}$ peritoneal cell suspension

Desintegration of bacteria in peritoneal cells was estimated by counting microscopically the number of bacteria in MAs and PMNLs before and after 5 and $10 \mathrm{~min}$ in vitro incubation of the cells at $37^{\circ} \mathrm{C}$ rolling the tubes with the cell suspension on a roller bank.

Preparation and determination of interferon. Mouse interferon I was a gift of Dr. H. Schellekens (Primate Center INO, Rijswijk, The Netherlands). The virus-induced interferon I was purified according to Allen et al. (1). The final preparation contained $10^{6}$ units per mg pratein. Interferon was determined in the intraperitoneal fluid of mice which were injected with $5 \mu \mathrm{g}$ RNA + $150 \mu \mathrm{g} \mathrm{DDA}, 10 \mu \mathrm{g} \mathrm{RNA}+150 \mu \mathrm{g}$ DDA, $150 \mu \mathrm{g} \mathrm{DDA}$, or with $0.1 \mathrm{ml}$ PBS.

At $0,3,6,16,24,48$, or $72 \mathrm{~h}$ after treatment mice were killed by cervical dislocation and $1 \mathrm{ml}$ of HBSS containing 50 units heparin was injected in their peritoneal cavity. Fluid and cells were collected and the cells were separated from the fluid by centrifugation. Peritoneal fluid of 3 mice was pooled and stored at $-20^{\circ} \mathrm{C}$.

The peritoneal fluids were tested for the presence of interferon by $\mathrm{Dr}$. H. Schellekens according to the method described by Allen et al. (1).

Statistical evaluation. Significance levels for the percentages of survival of mice were determined by the Fisher exact test as described by Bradley (3). Significance levels for differences between the numbers of peritoneal cells were calculated by the Student's t-Test (4).

RESULTS

Effect of injection route on protection and titers of anti-LPS antibodies induced by ribosomes + DDA, RNA + DDA, or LPS.

The protective activities of ribosomes + DDA, RNA + DDA, and LPS injected subcutaneously (sc) or intravenously (iv) against an intraperitoneally (ip) injected challenge containing 6.4 LD $_{50}$ of $P$. aeruginosa were compared with their protective activities after ip injection (Table 1). All preparations protected mice at lower doses when they were injected ip than after sc or iv injection. Hiqher doses of the ribosomes + DDA induced protection after sc or iv injection, while similar doses of RNA + DDA injected SC or iv 
Table 1. EFFECT OF INJECTION ROUTE OF THE RIBOSOMES, RNA DR LPS ON PROTECTION AND ANT IBOOY-TITERS TO LPS.

\begin{tabular}{|c|c|c|c|c|c|c|c|}
\hline \multicolumn{2}{|c|}{ Injected prepn. } & \multicolumn{3}{|c|}{ Survival $\left(\begin{array}{l}0 \\
0\end{array}\right)^{6}$} & \multicolumn{3}{|c|}{$\begin{array}{c}\log _{2} \text { titer }{ }^{b} \text { of antibodies to } \\
\text { LPS }\end{array}$} \\
\hline Type & Dose (1rg) & $\mathrm{sc}$ & iv & $\mathbf{i p}$ & $\mathrm{sc}$ & iv & ip \\
\hline \multirow[t]{3}{*}{ Ribosones+DDA } & 50 & 45 & 70 & - & 6.1 & 8.1 & - \\
\hline & 20 & 27 & 70 & - & 3.0 & 7.3 & - \\
\hline & 5 & $-{ }^{c}$ & 30 & 85 & - & 4.1 & 5.0 \\
\hline \multirow[t]{3}{*}{$R N A+D D A$} & 60 & 7 & 20 & - & 0.5 & 3.3 & - \\
\hline & 20 & 3 & 0 & - & 0.1 & 2.5 & - \\
\hline & 5 & - & 0 & 65 & - & 0.0 & 2.0 \\
\hline \multirow[t]{3}{*}{ LPS } & 0.1 & 5 & 45 & 75 & 4.8 & 8.2 & 8.7 \\
\hline & 0.01 & 0 & 30 & 41 & 2.8 & 6.5 & 6.9 \\
\hline & 0.001 & - & 0 & 22 & - & 5.3 & 5.6 \\
\hline Buffer + DDA & & 0 & 5 & 3 & 1.3 & 0.4 & 1.0 \\
\hline Buffer & & 5 & 5 & 0 & 0.6 & 0.1 & 1.3 \\
\hline
\end{tabular}

a Groups of 20 mice were injected subcutaneously ( $5 c$ ), intravenously (iv) or intraperitoneally (ip) with different preparations and challenged six days later intraperitoneally with a lethal dose of $P$. aeruginosa.

b The $\log _{2}$ titer of antibadies to LPS was determined by the ELISA gix days after treatment. Each nurnber represents the mean value of determinations on two different pools of sera of 5 mice.

c Not determined.

did not protect the mice against ip challenge. Iv or sc injection with the same preparations did not protect mice 2 days after this treatment except for the $s c$ injection with $50 \mu \mathrm{g}$ ribosomes + DDA (results not shown). Five $\mu \mathrm{g}$ ribosomes + DDA or $5 \mu \mathrm{g}$ RNA + DDA induced significant protection 2 days after ip injection (10). The percentages of survival correspond with the titers of anti-LPS antibodies induced by the ribosomes + DDA or by LPS. However, ribosomes + DDA induced higher percentages of survival in comparison with LPS at similar titers of anti-LPS antibodies. For example iv injection of $50 \mu \mathrm{g}$ ribosomes + DDA induced 70\% survival and an anti-LPS antibody titer of 8.1 , while $0.1 \mu \mathrm{g}$ LPS induced 


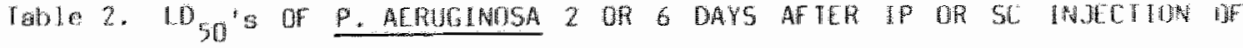

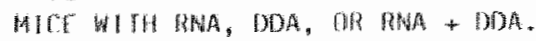

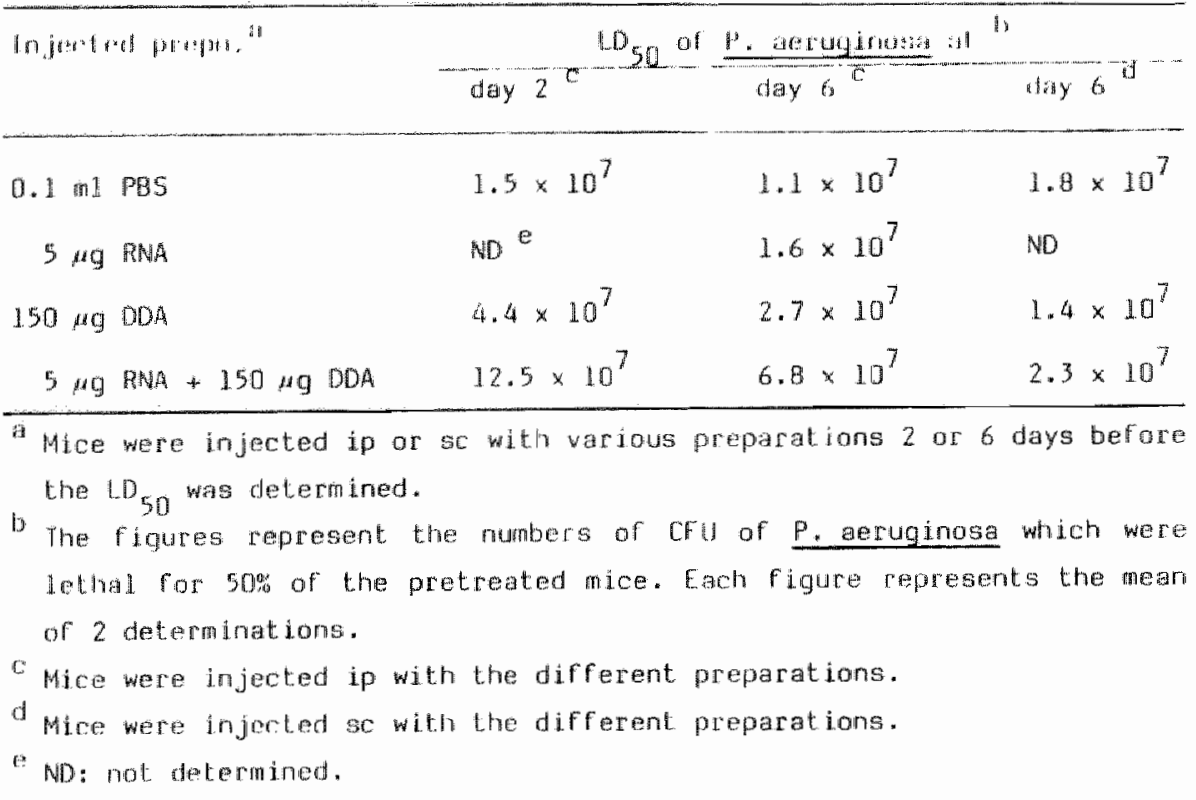

IGBIE 3. NLMBER OF DIFFERENT TYPES OF PERHIONEAL CCLL5 2 UR 6 DAYS AF ILR INJECTION OF MICE WITH DOA OR DDA + RRA.

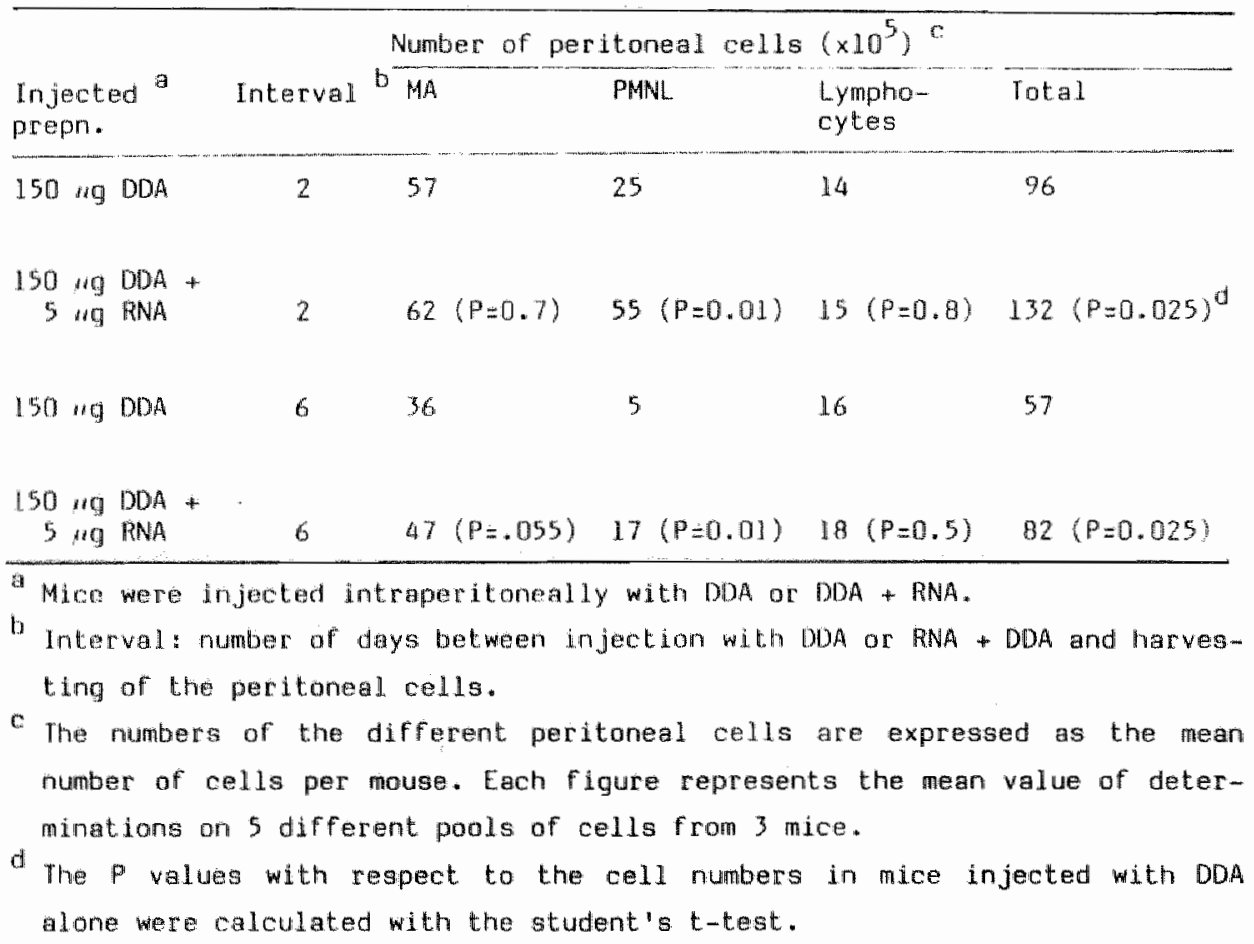


the same antibody titer but only $45 \%$ survival.

Determination of $L D_{50}$ 's of $P$. aeruginosa for mice treated with RNA \pm DDA, RNA, DDA, or PBS.

To quantify the resistance induced by $5 \mu \mathrm{g}$ RNA + $150 \mu \mathrm{g}$ DDA 2 or 6 days after injection the $L D_{50}$ of $P$. aeruginosa for mice treated with RNA + DDA has been compared with the LD 50 "s of mice injected with only DDA or RNA or with PBS. Two days after ip injection of DDA the resistance of mice for P. aeruginosa was increased 3 fold, while the addition of RNA to DDA increased the $L_{50}$ again 2.8 fold (Table 2 ). Six days after ip injection of DDA the $L_{50}$ was raised 2.5 fold, while addition of RNA to DDA increased the $L D_{50}$ again 2.5 fold. Injection of RNA without DDA only slightly increased the LD 50 in comparison with PBS. Sc injection of DDA did not increase the $L D_{50}$ of ip injected $P$. aeruqinosa 6 days later and Sc injection of RNA + DDA increased the $L_{50}$ only slightly.

Differential counts of peritoneal cells from mice injected with RNA, DDA or RNA + DDA.

To obtain information about the cell influx in the peritoneal cavity after ip injection of different preparations, differential counts have been made of peritoneal cells from mice treated with $0.1 \mathrm{ml}$ PBS, $5 \mu \mathrm{g}$ RNA, $150 \mu \mathrm{g}$ DDA, or $5 \mu \mathrm{g} \mathrm{RNA}+150 \mu \mathrm{g}$ DDA. The most renarkable influx of cells occurred after injection of DDA or RNA + DDA. Injection of RNA without DDA did not cause an increase in peritoneal cells in comparison with the cell numbers in PBS injected mice (Fig. 1).

The highest numbers of MAs and PMNLs were found from $16 \mathrm{~h}$ till 3 days after immunization with DDA or RNA + DDA. Six days after immunization the cell numbers in the peritoneum had declined. However, the peritoneal cavity of DDA injected mice contained still 1.5 fold more cells than that of PBS injected mice at this time, while mice injected with RNA + DDA had 1.6 fold more peritoneal cells than DDA injected mice.

Mice were injected with DDA or DDA + RNA and the numbers of peritoneal cells were determined repeatedly 2 and 6 days after treatment in order to find out whether they differed significantly. The total number of peritoneal. cells and the number of PMNLs were higher in mice injected with RNA + DDA than in mice injected with DDA alone, both 2 and 6 days after treatment (Table 3). The numbers of lymphocytes and MAs did not differ significantly, although the number of MAs in mice which were injected with RNA + DDA 6 days previously tended to be higher than in DDA injected mice. The morphology of MAs in mice injected with DDA and RNA + DDA was different from the morphology of MAs from PBS injected mice. The 


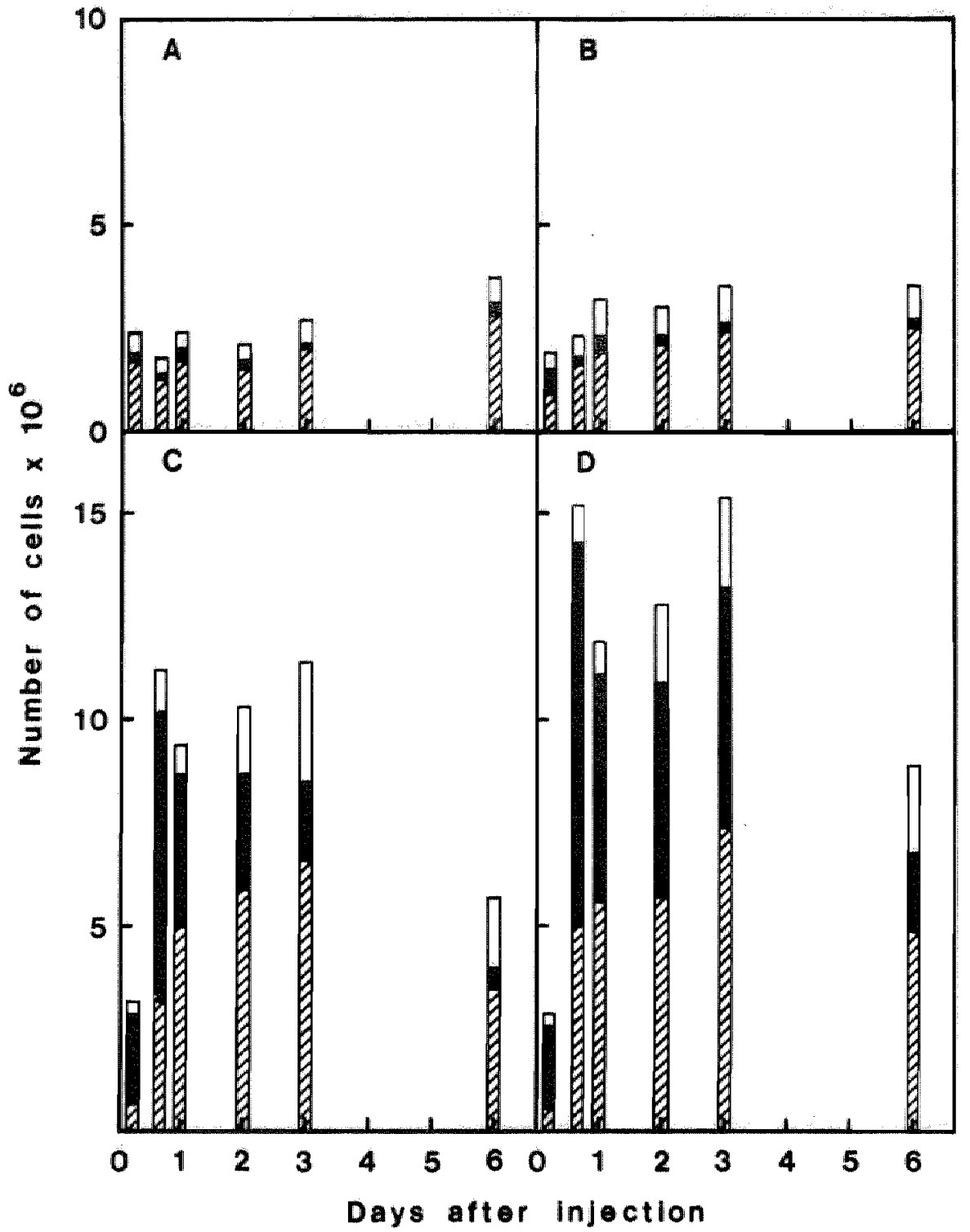

Flg. 1 Differential counts of peritoneal cells from differently treated mice. Peritoneal cells were obtained from mice at different intervals after intraperitoneal injection with $0.1 \mathrm{ml}$ PBS (A), $5 \mu \mathrm{RNA}$ (B), $150 \mu \mathrm{g}$ DDA (C), or $5 \mu \mathrm{g}$ RA + $150 \mu \mathrm{g}$ DDA (D). The number of peritoneal cells was determined and the cells were differentiated. The number of MAs ( $\square$ ), PMNLs ( $\square$ ) and lymphocytes ( $\square$ ) per mouse is indicated in the figures. Each value represents the mean of 3 determinations on different pools of peritoneal cells from 3 mice. 
former were larger and contained more granules and vacuolles than the latter (Fig. 2 ).

In vivo phagocytosis of $P$. aeruginosa by peritoneal cells of mice injected with RNA + DDA, DDA or PBS.

The phagocytic activity of peritoneal cells from mice injected ip 6 days previously with $5 \mu \mathrm{g}$ RA + $150 \mu \mathrm{g}$ DDA, $150 \mu \mathrm{g}$ DDA or with PBS was compared in two in vivo phagocytosis systems, which differed with respect to the number of bacteria injected in differently pretreated mice.

In both systems the $P$. aeruginosa bacteria were mixed with antiLPS antibodies prior to injection. Phagocytosis was allowed to occur during $4 \mathrm{~min}$ in vivo. Subsequently the peritoneal cells, loaded with bacteria, were harvested. The total numbers of viable and dead bacteria which were associated with the cells were determined microscopically, while the numbers of cell associated viable bacteria were determined by counting the CFU in a suspension of broken cells.

Table 4 represents the mean data of 3 experiments in which the same number of bacteria was injected in differently pretreated mice. Since injection of DDA and RNA + DDA induced increased numbers of peritoneal cells, the ratio of bacteria to cells was lower in these mice, than in PBS injected mice.

MAs from mice injected with PBS, DDA or RNA + DDA contained respectively $6.2,5.6$ and 3.6 bacteria per MA after 4 min phagocytosis. Although the MAs from RNA + DDA treated mice had ingested less bacteria per MA, the percentage of injected bacteria which was associated with the MAs from these mice was somewhat higher than for DDA treated mice, because the number of MAs obtained from RNA + DDA treated mice was higher. PMNLs from RNA + DDA injected mice took up $4 \%$ of the injected bacteria, i.e. only $12 \%$ of the total amount of cell associated bacteria, although the ratio of MAs to PMNLs was $2: 5: 1$. The percentage of the injected bacteria which was associated with MAs + PMNLs from RNA + DDA treated mice was 1.3 fold higher than for DDA treated mice, while MAs + PMNLs from the latter mice took up 1.5 fold more bacteria than MAs + PMNLs from PBS injected mice. The percentage of viable injected bacteria which was recovered as viable bacteria from peritoneal cells of RNA * DDA treated mice was somewhat lower than the percentage CFU recovered from cells of PBS or DDA treated mice. The percentage of peritoneal cell associated bacteria which was viable after 4 min phagocytosis was 1.9 fold higher for DDA treated mice than for RNA + DDA treated mice, while a 1.2 fold higher percentage of viable cell associated bacteria was found for PBS than for DDA treated mice.

The desintegration of bacteria in MAs or PMNLs from DDA or RNA * DDA injected mice was estimated by counting the number of bacteria 
A
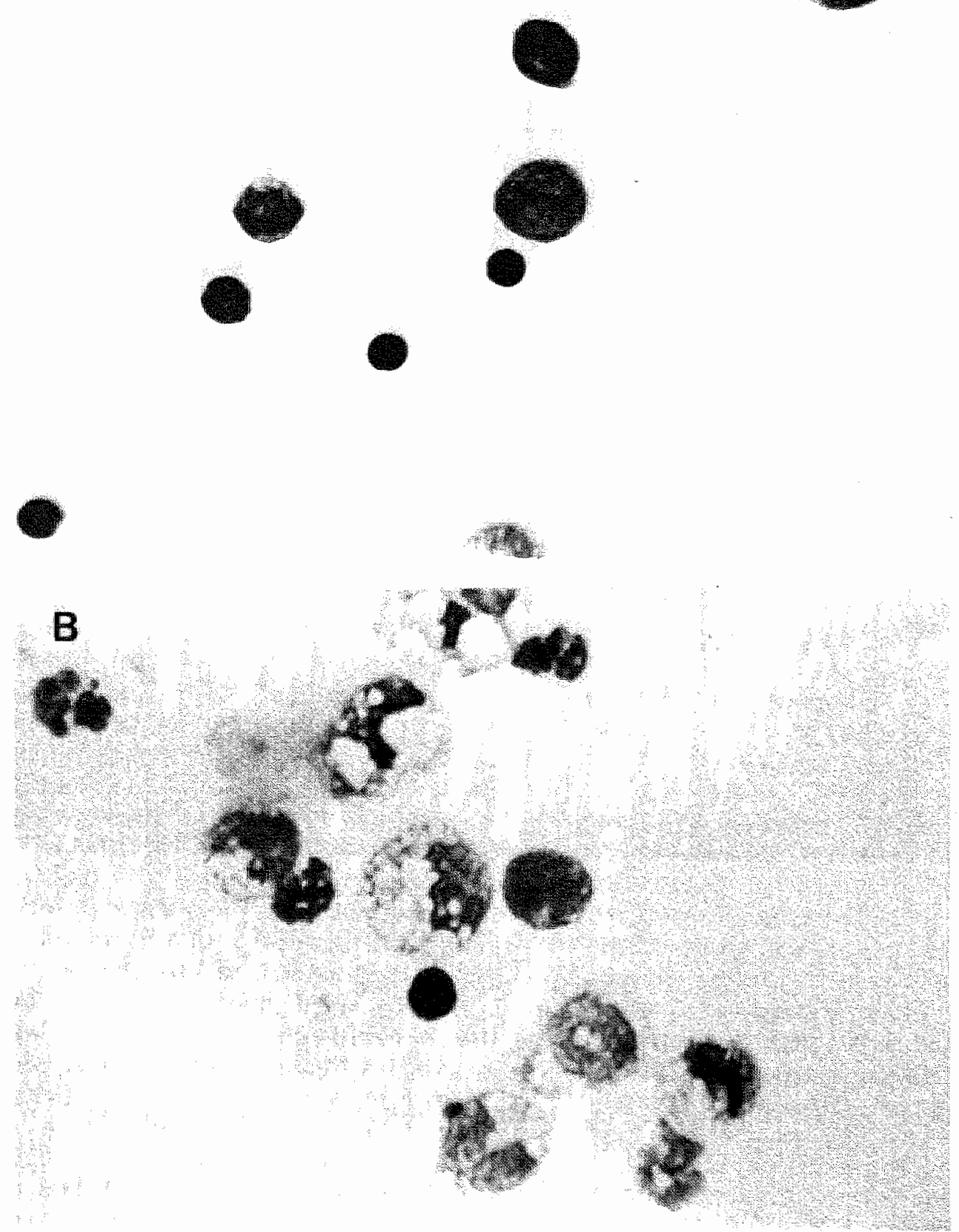

Fig. 2 Peritoneal exudate cells of treated mice. Mice were injected with $0.1 \mathrm{mll}$ PBS (A) or $150 \mu \mathrm{g}$ DDA (B) 2 days before harvesting of the peritoneal cells. 
TablR 4. IN VIVO PHAGOCYTOSIS OF P. AERUGINOSA BY PERITONEAL CELLS FRON DHFERENTLY TREATED MICE .

\begin{tabular}{|c|c|c|c|c|c|c|}
\hline $\begin{array}{l}\text { Injected b } \\
\text { prepn. }\end{array}$ & $\begin{array}{l}\text { Ratio of } \\
\text { injected } \\
\text { bacteria } \\
\text { to perito- } \\
\text { neal cellsc }\end{array}$ & $\begin{array}{l}\text { : Uptake } \\
\text { by MAs }\end{array}$ & $\begin{array}{l}\text { \% Lptake } \\
\text { by PlwNLs }\end{array}$ & $\begin{array}{l}\text { Of Uptake } \\
\text { MAs+PMNLs }\end{array}$ & $\begin{array}{l}\text { CFU in } \\
\text { peritoned } \\
\text { cells }\end{array}$ & $\begin{array}{l}\text { \% Viable of } \\
\text { peritoneal } \\
\text { cell asso- } \\
\text { ciated bac- } \\
\text { teria }\end{array}$ \\
\hline PQS & 22.9 & 20.5 & - & 20.5 & 11.5 & 47 \\
\hline $150,4 \mathrm{DDA}$ & 14.2 & 29.1 & 0.9 & 30.0 & 13.4 & 38 \\
\hline $\begin{array}{c}150 \mathrm{Hg} \text { DDA+ } \\
5 \mathrm{Hg} \text { RNA }\end{array}$ & 7.0 & 34.1 & 4.2 & 38.3 & 8.1 & 20 \\
\hline
\end{tabular}

${ }^{a}$ Pretreated mice were injected intraperitoneally with $6.6 \times 10^{7} \mathrm{P}$. aeruginosa, opsonized with anti-LPS antibodies and phagocytosis was allowed to nccur during $4 \mathrm{~min}$ in vivo. Determinations were perfarmed on washed peritoneal cell suspensions. The number of injected $P$. aeruginose was counted microscopically. All figures represent the mean values of three experiments.

b Mice were injected intraperitoneally with PBS, DDA or RNA + DDA 6 days prior to the injection of bacteria.

c The ratios of microscopically counted numbers of injected bacteria to the total numbers of peritoneal cells per mouse are presented.

Table 5. IN VIVO PHAGOCYTOSIS OF P. AERUGINOSA BY PERITONEAL CELLLS FROM DIFFERENTLY TREATED MICE. AT ABOUT EQUAL BACTERIA TO CELL RATIOS ${ }^{\circ}$.

\begin{tabular}{|c|c|c|c|c|c|c|}
\hline $\begin{array}{l}\text { Injecteg } \\
\text { prepn. }\end{array}$ & $\begin{array}{l}\text { Ratio of } \\
\text { bacteria } \\
\text { to perito- } \\
\text { neal cells" }\end{array}$ & $\begin{array}{l}\text { uptake } \\
\text { by MAs }\end{array}$ & $\begin{array}{l}\text { : Uptake } \\
\text { by PMNLs }\end{array}$ & $\begin{array}{l}\text { of Uptake } \\
\text { by MAs + } \\
\text { PMNLs }\end{array}$ & $\begin{array}{l}\text { a cFu in } \\
\text { perito- } \\
\text { neal } \\
\text { cella }\end{array}$ & $\begin{array}{l}\text { \% Viable of } \\
\text { peritoneal } \\
\text { cell aseoriam } \\
\text { ted bacterila }\end{array}$ \\
\hline PBS & 0.0 & 23 & 0.5 & 23.5 & 9.8 & 24 \\
\hline $150 \mathrm{ug} D D A$ & 10.2 & 24 & 1.7 & 25.7 & 6.5 & 16 \\
\hline $\begin{array}{c}150 \% \mathrm{H} \text { DDA+ } \\
5 \% \mathrm{gNA}\end{array}$ & 8.8 & 23 & 3.1 & 26.1 & 7.5 & 18 \\
\hline
\end{tabular}

a Pretreated mice were injected intraperitoneally with p. aeruginosa opsow nized with anti-LPS antibodies and phagocytosis was allowed to occur during $4 \mathrm{~min}$ in viwo. Determinations were performed on washed peritoneal cell sus pensions. All figures represent the mean values of 4 experiments.

b Mice were injected with PBS, DDA or RNA + DDA, 6 days prior to the injection of the bacteria.

c Patios of microscopically counted numbers of injected bacteria to the total numbers of peritoneal cells per mouse. 
in these cells (harvested after 4 min ir vivo phagocytosis) before and after 5 and 10 min in vitro incubation at $37^{\circ} \mathrm{C}$. Similar results were obtained for cells from DDA or RNA + DDA treated mice. In MAs and PMNLs respectively $15^{\circ}$ and $19^{\circ}$ less bacteria were counted on an average after 5 min in vitro incubation.

Table 5 represents the mean data of 4 phagocytosis experiments im which differently treated mice were injected with such a number of bacteria that similar ratios of bacteria to peritoneal cells in these mice were obtained. The mean ratios of injected bacteria to peritoneal cells in mice injected with PBS, DDA or RNA + DDA were respectively $8.0,10.2$, and 8.8 . The MAs from these differently treated mice contained similar numbers of bacteria per MA (respectively $2.4,3.6$, and 3.5 per MA from PBS, DDA, or RNA + DDA injected mice). Equal percentages of injected bacteria were ingested by the MAs. The contribution of the PMNLs to the phagocytosis of $P$. aeruginosa was very low: maximal $3.1 \%$ of the injected bacteria. The percentage of viable injected $P$. aeruginosa which was recovered from the peritoneal cells as viable bacteria was also similar for cells from PBS, DDA, or RNA + DDA injected mice. The sonewhat higher percentage for PBS injected mice was due to one exceptional high value.

Also the percentage of peritoneal cell associated bacteria that was viable after $4 \mathrm{~min}$ phagocytosis did not vary significantly for differently treated mice.

Interferon titers in the peritoneal fluid of mice and protective activity of interferon against $P$. aeruginosa.

Interferon activity was determined in the peritoneal fluid of mice injected with $5 \mu \mathrm{g}$ or $10 \mu \mathrm{g}$ RNA + 150 $\mu \mathrm{g}$ DDA, $150 \mu \mathrm{g}$ DDA or $0.1 \mathrm{ml}$ PBS. No interferon activity was found $0,3,6,16,24,48$ or $78 \mathrm{~h}$ after injection of these preparations (results not shown). To lest whether interferon might be capable to increase the resistance against $P$. aeruginosa purified mouse interferon $\mathbb{I}$ was injected ip in mice which were challenged 2 days later with $P$. aeruginosa. Interferon did not raise significantly the survival percentages (Table 6$)$.

\section{DISCUSSION}

The ribosomal vaccine of $P$. aeruginosa has appeared to be a multicomponent vaccine, in which both traces of contaminating LPS and ribosomal. RNA contributed to the protective activity. The LPS induced serotype-specific antibodies (9) whereby higher percerntages of survival were obtained with the ribosomal vaccine after homologous than after heterologous challenge. RNA was responsible For the nonspecific protection induced by the ribosomal vaccine. 


\begin{tabular}{lll}
\hline Prepn. a & Dose & Survival (M) b \\
\hline Interferon & 20.000 Units & $20(10)^{\mathrm{c}}$ \\
RNA + DDA & 100.000 Units & $14(7)$ \\
PBS & $5 \mu 9+150 \mu 9$ & $80(10)$ \\
DDA & $0.1 \mathrm{ml}$ & $10(20)$ \\
\hline
\end{tabular}

a The preparations were injected intraperitoneally.

b Mice were challenged with $p$. aerucinosa 2 days after injection with the different preparations.

C The figures in parentheses represent the number of mice.

In addition RNA had adjuvant activity for the contaminating LPS (10). Both the ribosomal vaccine and purified RNA had to be combined with the adjuvant DDA in order to obtain optimal protection $(8,10)$.

Since the protection by ribosomal RNA + DDA was nonspecific and detectable as quickly as one day after injection (10), it seemed unlikely that $B$ or $T$ lymphocytes were involved in the protective mechanism. This concept was supported by the finding that protection induced by RNA + DDA could not be transferred with serum of RNA + DDA treated mice (results not shown). Instead the features of the protection induced by RNA + DDA suggested that the resistance was due to an enhanced activity of the phagocytic system of the host.

The ribosomal vaccine protected mice after iv or sc immunization against ip challenge. Protection by the ribosomal vaccine was associated with the presence of anti-LPS antibodies. However, the systemic immunity induced by the ribosomes + DDA could not entirely be explained by the anti-LPS antibodies, since antibody titers induced by the ribosomes + DDA were associated with higher percentages of survival than similar antibody titers induced by purified LPS. Such a discrepancy between antibody titers and percentages of survival was previously reported after an ip injection of mice with ribosomes + DDA and LPS (9). In this case the higher survival rate induced by the ribosomal vaccine could be ascribed to the contribution of RNA + DDA to the protection (Tables 1 and 2) (10). However, SC or iv injected RNA + DDA did not induce significant protection against an ip administered $P$. aeruginosa challenge, suggesting that RNA + DDA induced only local resistance. Ip injec- 
tion of only DDA increased the $\mathrm{LD}_{50}$ of $\mathrm{P}$. aeruginosa for mice, while addition of RNA to DDA increased the LD50 again several fold. Sc injected DDA did not raise the $L_{50}$ and sc injected RNA + DDA raised the $L D_{50}$ only slightly. A slightly increased $L_{50}$ was also observed when RNA without DDA was injected ip. These results demonstrated that protection by ip injected RNA + DDA was in part due to a local resistance induced by DDA which was augmented by the addition of RNA to DDA. The findings that sc or iv injected ribosomes + DDA induced thigher percentages of survival than LPS at similar anti-LPS antibody titers, and that sc injected RNA + DDA

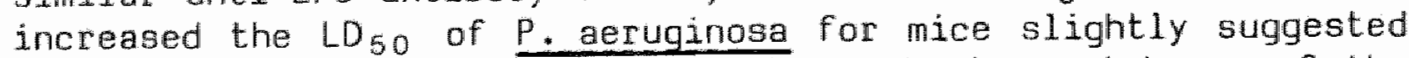
that RNA might have an effect on the systemic resistance of the host.

To study whether the quickly induced local protection by DDA and RNA + DDA might be associated with the influx of phagocytic cells in the peritomeal cavity the peritoneal cells from differently pretreated mice were counted. Injection of DDA alone induced increased numbers of peritoneal cells in comparison with injection of PBS both 2 and 6 days after treatment. Injection of RNA + DDA induced higher numbers of peritoneal cells, in particular higher numbers of PMNLs, than injection of only DDA. RNA alone did not attract more peritorieal cells than PBS.

Although higher numbers of peritoneal cells in treated mice were associated with higher $L D_{50}$ 's of $P$. aeruqinosa for these mice, there was no clear quantitative correllation between the peritoneal cell number and the $L_{50}$. For example, mice treated 2 days previously with DDA contained $1.0 \times 10^{7}$ peritoneal cells and the LD 50 was $4.4 \times 10^{7} \mathrm{CFU}_{\text {, }}$ while mice treated 6 days previously with RNA + DDA had $8.6 \times 10^{6}$ peritoneal cells and the LD 50 was 6.8 $\times 10^{7}$ CFU. Nevertheless it was likely that the increased numbers of phagocytic cells induced by DOA and RNA + DDA were at least in part responsble for the higher resistance of treated mice. Since in particular the numbers of PMNLs were increased in RNA + DDA injected mice, the contribution of PMNLs to the phagocytic activity of the peritoneal cells was of particular interest. In addition the morphology of MAs from DDA or RNA + DDA treated mice suggested that these cells were stimulated by DDA.

An in vivo phagocytosis system was used to appraach the question whether increased numbers of peritoneal cells and/or stimulation of phagocytic cells were responsible for the resistance of RNA + DDA and DDA treated mice. These experiments had to be performed with opsonized $P$. aeruginosa bacteria since without antiLPS antibodies almost no bacteria were ingested.

When equal numbers of bacteria were injected in mice which were treated 6 days previously with PBS, DDA, or RNA + DDA it appeared that increased numbers of peritoneal cells took up increased percentages of the injected bacteria. However, the total uptake of bacteria did not increase proportionally with the number of peri- 
toneal cells since a lower ratio of bacteria to cells resulted also in a lower number of bacteria per MA. For example, while 2 fold more peritoneal cells were obtained from RNA + DDA injected mice than from DDA treated mice, the cells from the former group took up only 1.3 fold more of the injected bacteria. The percentage of peritoneal cell-associated viable bacteria was lower in cells from RNA + DDA treated mice than in cells from DDA treated mice, suggesting that the killing was more efficient in the former group. This might be due to the fact that MAs from RNA + DDA treated mice contained less bacteria per MA than MAs from DDA treated mice.

When the ratio of injected bacteria to peritoneal cells was similar for PBS, DDA and RNA + DDA treated mice MAs from these mice had ingested similar percentages of injected bacteria after 4 min phagocytosis. The PMNLs from RNA + DDA injected mice took up only $3 \%$ of the injected bacteria and did not influence the total percentage of the uptake by the peritoneal cells significantly. The percentage of cell associated viable bacteria was similar for differently treated mice.

Since the phagocytosis experiments were performed with apsonized $P$. aeruginosa bacteria it is uncertain whether the results apply to the situation in the protection experiments, in which RNA and DDA were tested without anti-LPS antibodies. The phagocytosis experiments suggested that MAs from DDA or RNA + DDA treated mice had no enhanced capacity to ingest or kill $P$. aeruginosa. The higher $L D_{50}$ 's of $P$. aeruginosa for DDA and RNA + DDA treated mice might be due - at least in part - to the increased numbers of peritoneal cells in these mice which are able to ingest more of the injected bacteria. In addition the lower ratio of bacteria to peritoneal cells in RNA + DDA and DDA treated mice resulted in a lower bacterial load of the MAs and a better killing of the ingested bacteria. However, another mechanism might also contribute to the resistance of RNA + DDA treated mice, since there are discrepancies between the increase in the peritoneal cell-number and the increase in $L D_{50}$, and there are indications that RNA + DDA increased the systemic resistance of the host slightly.

Araujo and Remington (2) reported that 200 micrograms of toxoplasma RNA activated mouse macrophages, measured as resistance to challenge with Listeria monocytogenes in vitro. Activation of macrophages was detected 15 but not 30 days after injection of RNA, while mice were only 30 but not 15 days after treatment protected against challenge with toxoplasma. These results suggest that special conditions are required to detect enhanced activity of macrophages.

The contribution of PMNLs to phagocytosis of $P$. aeruginosa was in our system almost negligible in comparison with the phagocytic activity of the MAs. In particular PMNLs took up less bacteria per cell than MAs. In other systems quite different results have been 
obtained. Bullen et al. (5) concluded that resistance against $P$.

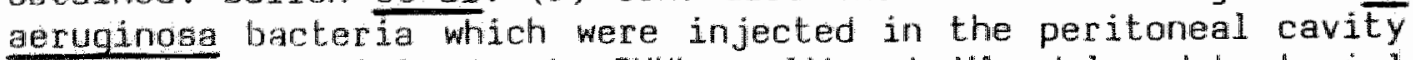
of rabbit was mainly due to PMNLs, although MAs delayed bacterial growth for several hours. Tatsukawa et al. (19) reported that the resistance of mice against iv injected $P$. aeruginosa was mainly due to carrageenan insensitive phagocytes, i.e. PMNLs. Peterson et al. (15) found that human PMNLs ingested in vitro approximately Ewice as much bacteria (Staphylococcus aureus, Escherichia coli or Listeria monocytogenes) Ehan MAs. Microscopic counting of bacteria might be misleading because of a rapid desintegration of intracellular bacteria. Comparing the disappearance of microscopic visible, cell associated bacteria in MAs and PMNLs during $5 \mathrm{~min}$ in vitro incubation no significant differences were found between the desintegration rate of bacteria in MAs or PMNLs. However, phagocytosis experiments with labeled $P$. aeruginosa are required to ascertain the contribution of the PMNLs to the ingestion of the bacteria.

Robert et al. (18) reported that bacterial ribosomes induced interferon in mice. Interferon has been found to stimulate the phagocytic activity of macrophages $(6,14)$. Such a mechanism might explain the induction of nonspecific resistance by RNA. However, no interferon activity has been found in the peritoneal fluid of RNA + DDA treated mice. Also ip injection of purified interferon did not increase the resistance of mice to $P$. aeruginosa. Thus it is unlikely that the nonspecific resistance induced by ribosomal RNA + DDA was due to the induction of interferon.

Although the degree of nonspecific resistance induced by RNA + DDA is small in terms of increase of $L_{50}$ the studies on the protective activity of the ribosomal vaccine of $P$. aeruginosa suggested that the nonspecific resistance induced by RNA + DDA contributed effectively to protection induced by this multicomponent vaccine. It has been shown that the ribosomal vaccine could effectively protect mice at relatively low anti-LPS antibody titers (Table 1) (9). Likewise, application of RNA + DDA might increase the effectivity of naturally occuring antibodies. Another interesting property of RNA is its adjuvant activity which might facilitate the use of relatively toxic antigens in multicomponent vaccines. It is not yet clear whether the adjuvant activity of RNA is nediated by its property to attract phagocytic cells, since RNA attracted in particular PMNLs which are not involved in the induction of specific immunity like the MAs.

\section{ACKNOWLEDGEMENTS}

We are indebted to $H$. Schellekens (Primate Center TNO, Rijswijk, The Netherlands) for his generous gift of mouse interferon and for the determination of interferon. 
1. Allen, P.T., H. Schellekens, L.J.L.D. van Griensven and A. Billiau. 1976. Differential sensitivity of Rauscher murine leukemia virus (MuLV-R) to interferons in two interferonresponsive cell lines. J. Gen. Virology 31: 429-435.

2. Araujo, F.G. and J.S. Remington. 1974. Protection against Toxoplasma gondii in mice immunized with toxoplasma cell fractions, RNA, and synthetic polyribonucleotides. Immunology 27: $711-721$.

3. Bradley, J.V. 1968. Distribution free statistical tests, $p$. 216-226. Prentice-Hall Inc., Englewood Cliffs, N.J.

4. Brownlee, KA. 1965. Statistical theory and methodology in science and engineering. John Wiley \& Sons, N.Y.

5. Bullen, J.J., S.N. Wallis and E. Griffiths. 1976. The effect of antipolymorphonuclear leucocyte serum on Pseudomonas aeruginosa infection in rabbits. Immunology 30: $60 \overline{3-610 .}$

6. Degré, M. and H. Rollag. 1979. Influence of interferon on the in vivo phagocytic activity of reticuloendothelial system cells. J. Reticuloendoth. Soc. 25: 489-493.

7. Galanos, C., D. Luderitz and 0. Westphal. 1969. A new method for the extraction of R. lipopolysaccharides. F.ur. J. Biochem. 9: $245-249$.

8. Conggrijp, R., W.J.H.A. Mullers, P.J.M.R. Lemmens and C.P.A. van Boven. 1980. Ribonuclease sensitive ribosomal vaccine of Pseudomonas aeruginosa. Infect. Immun. 27: 204-210.

9. Gonggrijp, R., M.P.W. Volleberg, P.J.M.R. Lemmens and C.P.A. van Boven. 1981. Evidence for the presence of lipopolysaccharide in a ribonuclease-sensitive ribosomal vaccine of Pseudomonas aeruginosa. Infect. Immun. 31: 896-905.

10. Conggrijp, R., W.J.H.A. Mullers and C.P.A. van Boven. 1981. Serotype-nonspecific protection induced by ribonucleic acid isolated from the ribosomal vaccine of Pseudomonas aeruginose. Infect. Immun. 33: 178-185.

11. Hartree, E.F. 1972. Determination of protein: a modification of the Lowry method that gives a linear photonetric response. Anal. Biochem. 48: 422-427.

12. Herbert, D., P.H. Phipps and R.E. Strange. 1971. Chemical analysis of microbial cells, p. 308-328. In J.R. Norris and D.W. Ribbons (ed.), Methods in Microbiology, vol. 5B. Academic Press Inc., London.

13. Horton, D. and G. Rodemeyer. 1977. Analytical characterization of lipopolysaccharide antigens from seven strains of Pseudomonas aeruginosa. Carbohydr. Res. 55: 35-47. 
14. Manejias, R.E., S.J. Hamburg and M. Rabinovitch. 1978. Serum interferon and phagocytic activity of macrophages in recombinant inbred mice inoculated with Newcastle disease virus. Cell. Immunal. 38: 209-213.

15. Petersan P.J., J. Verhoef, P. Schmeling and P.G. Quie. 1977. Kinetics of phagocytosis and bacterial killing by human polymorphonuclear leukocytes and monocytes. J. Infect. Dis. 136: 502-509.

16. Poulsorn, R. 1977. Isolation, purification, and fractionation of RNA, p. 343-344. In P.R. Stewart and D.S. Letham (eds.), The ribonucleic acids, 2nd ed. Springer Verlag Inc., New Yark.

17. Reed, L.J. and H. Muench. 1938. A simple method for estimating fifty percent endpoints. Am. J. Hyg. 27: 493-497.

18. Robert, D., J.P. Quillon, B. Ivanoff, Y. Beaudry, R. Fontagnes, G. Normier, A.M. Pinel and L. Dussourd d'Hinterland. 1979. Role of interferon in mice in protection against influenza $A$ virus by bacterial ribosames together with membranal. glycoproteins of Klebsiella pneumoniae as adjuvant. Infect. Immun. 26: 515-519.

19. Tatsukawa, K., M. Mitsuyama, K. Takeya and K. Nomoto. 1979. Differing contribution of polymorphonuclear cells and macrophages to protection of mice against Listeria monocytogenes and Pseudomonas aeruginosa. J. Gen. Microbial. 115: 161-166.

20. Weissbach, A. and J. Hurwitz. 1959. The formation of 2-keto-3deoxyheptonic acid in extracts of Escherichia coli B. I. Identification. J. Biol. Chem. 234: 705-709. 


\section{Chapter 9}

\section{General discussion}

The experimental work on the ribonuclease (RNase) sensitive ribosomal vaccine of Pseudomonas aeruginosa which is presented in this thesis revealed that this vaccine was a multicomponent vaccine in that both a contaminating cell surface antigen i.e. Iipopolysaccharide (LPS) and a ribosomal component, namely ribonucleic acid (RNA), contributed to the protective activity (Chapter 5, 6). Both the ribosomal vaccine, and purified RNA, had to be combined with the adjuvant dimethyldioctadecylammonium bromide (DDA) in order to exert their protective activity. RNA + DDA induced nonspecific protection against different $P$. aeruginosa serotypes as well as against non-related bacterial species i.e. Escherichia coli (Chapter 7). The nonspecific protection might be due in part to the attraction of phagocytic peritoneal cells by RNA + DDA (Chapter 8).

In addition RNA functioned as an adjuvant for the contaminating LPS and enhanced the production of antibodies to LPS (Chapter 6). It is not yet clear whether RNA had to be combined with the adjuvant DDA in order to exert its adjuvant function. Recent 1 y Butler et al. (5) reported that the ribosomal vaccine and RNA from Salmonella typhimurium - without application of an adjuvant - enhanced the primary in vitro antibody response of normal mouse spleen cell cultures to sheep erythrocytes. Also the adjuvant activity of synthetic polyadenylic polyuridylic acid (poly A.U) is well documented $(6,10)$.

The ribosomal vaccine + DDA induced nonspecific protection, but higher percentages of survival were obtained after homologous than after heterologous challenge since the anti-LPS antibodies induced by the ribosomal vaccine only enhanced clearance of homologous bacteria (Chapter 6).

The first question which will be discussed in this chapter is whether the multicomponent vaccine-model which is outlined above for the ribosomal vaccine of $P$. aeruginosa also applies to other ribosomal vaccines. Although various methods have been used to prepare ribosomal vaccines, the different results obtained with these vaccines probably do not result from the different purification methods but mainly from the differences between the protocols, in which the ribosomal preparations were tested for their protective activity.

The ribosomal vaccine of $P$. aeruginosa caused only optimal protection when four conditions were fulfilled, namely i) the 
ribosomal preparation had to be mixed with DDA prior to injection (Chapter 4, 6); II) the ribosomal vaccine had to be injected intraperitoneally i.e. via the same route as the challenge injection (Chapter 6, 8); III) the challenge injection had to be given within 6 days after injection of the ribosomal preparation (Chapter 6), and IV) the challenge dose should be rather low i.e. not higher than the dose which is required to kill 90 to $100 \%$ of the DDA treated controls. Under these conditions 5 micrograms of ribosomes or RNA induced significant protection. In literature none of the protocols in which ribosomal vaccines were tested, fulfilled these conditions, except for the protocol in which the ribosomal vaccine of Listeria monocytogenes was evaluated (14). However, the first two conditions might be overcome by increasing the dose of the ribosonal vaccine. Fifty micrograms of $P$. aeruginosa ribosomes + DDA induced protection after intravenous or subcutaneous injection (Chapter $4, B$ ), and significant protection was induced by the intraperitoneally injected ribosomal vaccine without DDA (Chapter 6). In most studies doses over 5 micragrams of the ribosomal preparations were applied. Also the limitation for the height of the challenge dose (condition IV) probably depends on the concentration of the ribosomal vaccine applied. The adjuvant function of DDA for the ribosomal RNA (condition II) might also be exerted by contaminating substances in the ribosomal preparation.

Youmans and Youmans suggested that a membranous substance in the particulate fraction of $M$. tuberculosis functioned as an adjuvant for the ribosomes, since the particulate fraction protected without adjuvant, while the ribosomes which were isolated from the particulate fraction had to be incorporated in Freund's Incomplete Adjuvant in order to be effective (15). Dussourd d'Hinterland et al. (8) have added purified Klebsiella pneumoniae cell wall proteoglycans to their ribosomal vaccine to increase its protective activity.

The third condition which refered to the restricted duration of the protection by the $r$ ibosomal vaccine of $P$. aeruginosa presents, however, a more essential difference between our protacol and those in which most ribosomal vaccines were tested. In most protocols the challenge was given 2 weeks or longer after immunization with the ribosomal preparation. Studies on the ribosomal vaccine of $P$. aeruginosa demonstrated that the two mechanisms which contributed to the protection had their optimal effects at different intervals after injection of the ribosomes. During the first two days after treatment with the ribosomes, the protection was entirely due to the nonspecific protection by RNA + DDA. Three to four days after treatment anti-LPS antibodies appeared and contributed to the specific protection (Chapter 6). The purified ribosomal vaccine of $P$. aeruginosa induced only low concentrations of antiLPS antibodies which were insufficient to cause significant pro- 
tection without the support of the nonspecific resistance (Chapter $5,6)$.

Thus in our studies the second phase specific protection was superimposed on the first phase nonspecific protection, and the specific protection lasted not longer than the nonspecific protection. The lower titers of antibodies induced by the ribosomal vaccine of $P$. aeruginosa probably reflected the low concentration of LPS in this preparation. It is likeIy that ribosomal vaccines which contain a higher concentration of cell surface antigens will induce a longer and stronger specific second phase protection. According to this concept a protocol in which the challenge was given two weeks or longer after injection of a ribosomal vaccine yields primarily information on the immunity induced by the contaminating cell surface antigens. Depending on the nature of the antigens and the immunization protocol, this immunity might be mediated by either antigen - specific antibodies or by specific effector T lymphocytes.

Although the protocols in which most ribosomal vaccines were tested did not permit detection of the nonspecific protective activity of RNA, the adjuvant activity of RNA for the contaminating antigens might have been detected for example by the RNase sensitivity of such a vaccine. However, most of the ribosomal vaccines appeared to be insensitive to RNase. Whether or not the contribution of RNA as adjuvant to the protective activity of a ribosomal vaccine will become detectable may be a matter of balance: the concentration of the contaminating cell surface antigens and their immunogenicity on one hand, and the physical state of RNA and possibly the presence of RNA complexing or stabilizing substances in the ribosomal preparation on the other.

The ribonuclease sensitive ribosomal vaccine of Streptococcus pneumoniae might be an example of a vaccine in which RNA had an important adjuvant function (3). However, since most ribosomal vaccines appeared to be insensitive to ribonuclease, the scale might easily dip to the other side.

From these considerations it is postulated that the RNase sensitivity of ribosomal vaccines has not been detected because of the degree of contamination of these preparations and the protocols in which the vaccines were tested. However, according to this hypothesis each ribosomal vaccine should be able to induce nonspecific protection when the proper protocol is applied, and the adjuvant function of RNA should be detectable when the vaccines were further purified.

The validity of this hypothesis might be tested by evaluating the knowledge about the few RNase sensitive vaccines which have been described in literature. RNase sensitive ribosomal vaccines have been prepared from 5. pneumoniae (3), Toxoplasma gondi i (2), Pasteurella multocida (4), Francisella tularensis (1), Histoplasma capsulatum $(9,13)$, Mycobacterium tuberculosis $(16,17)$, and Lis- 
teria monocytogenes (14). Each of these vaccines were tested in protocols in which the challenge was given 2,3 , or 4 weeks after immunization, except for the vaccine of $L$. monocytogenes. According to our hypothesis the RNase sensitivity of these vaccines probably points to the adjuvant function of RNA for contaminating cell envelope antigens in the preparations. It is likely that the ribosomal vaccine of $H$. capsulatum contains cell surface antigens, since this vaccine was also sensitive to pronase (9), it induced specific immunity, and purified RNA was poorly protective 3 weeks after injection (13). Similar results were obtained with the ribosomal vaccine of P. multocida. Protection was obtained by injection of 250 to 1000 micrograms of ribosomes, but not with RNA (4). An adjuvant function of RNA in the RNA extract of F. tularensis was suggested by the finding that opsonic antibodies were induced after injection of the RNA preparation. Since only crude but not purified ribosames of 5 . pneumoniae induced protection, RNA was likely to have an adjuvant function for contaminants in this crude ribosomal preparation as well (3). Few information is available on the induction of nonspecific protection by these vaccines. Youmans and Youmans reported that the mycobacterial ribosomal vaccine could induce nonspecific resistance during the first days after injection, while the protection was specific 4 weeks after immunization $(7,12)$. These findings fit our model on a nonspecific first phase and a specific second phase protection. Which cell surface antigen might contaminate the ribosomal vaccine of M. tuberculosis remains an open question since Youmans and Youmans never have found an indication for such contaminants in their ribosomes. The nonspecific protection induced by 200 micrograms of toxoplasma or mammalian RNA against challenge with $I$. gondii did not fit our model since this protection was detectable 30 but not 15 days after treatment (2).

However, short lasting nonspecific protection by pseudomonas RNA was regularly induced with a dose of 5 inicrograms, and the effect of doses as high as 200 micrograms on the duration of the protection has not been determined.

Immunity against extracellular bacteria is dependent on the presence of opsonizing antibodies while immunity to intracellular parasites is primarily mediated by $T$ lymphocytes. The $T$ lymphocytes activate macrophages which nonspecifically kill the intracellular parasites. RNase sensitivity seemed to occur more frequently among ribosomal or RNA preparations from intracellular parasites: all the above mentioned vaccines originated from such microorganisms, except for those from S. pneumoniae and P. aeruginosa. Therefore ribosomal RNA might more effectively stimulate those defence mechanisms of the host that are required for the destruction of intracellular parasites. RNA might be a more potent adjuvant for the induction of $\mathrm{T}$ cell mediated immune responses. In addition RNA might stimulate or activate the host's macrophages. 
Both of these possibilities are realistic in view of the extensive studies on the immunoregulatory action of synthetic polyribonucleotides, in particular polyadenylic - polyuridylic acid (poly (A.U)) (6, 10). Also, activation of macrophages by toxoplasma RNA has been reported (2). In contrast, in vivo phagocytosis experiments with opsonized $P$. aeruginosa did not yield indications that macrophages were activated (Chapter 8). Elucidation of the mechanism whereby ribosomal RNA exerts its protective effects certainly deserves priority since insight in these mechanisms might facilitate the proper applications of ribosomal RNA.

In conclusion we think that each ribosomal vaccine contained similar protective components, i.e. contaminating cell surface antigens and RNA. Whether or not the protective activities of RNA came to expression by RNase sensitivity of the vaccine depended principally on the protocol in which the vaccine was tested, the degree of contamination of the vaccine and the nature of the immune response which was required to eliminate the challenging organism.

The second question which will be discussed briefly in this chapter is whether a ribosomal vaccine of $P$. aeruginosa might have advantages over the LPS vaccines of which the applicability in burn patients is evaluated in clinical trials. The ribosomal vaccine combines two protective effects, i.e. a - mainly local increased nonspecific resistance and a systemic specific immunity which is supported by the adjuvant function of RNA. To obtain effective immunity with the ribosomal vaccine parenteral immunization should be combined with local application of the preparation at the sites where an infection with $P$. aeruginosa is expected. Local application of the ribosomal preparation at the most prevalent infection routes is expected to result in a nonspecific inhibition of the multiplication of microorganisms at that site, while parenteral immunization might lead to specific systemic immunity.

An advantage of the ribosomal vaccine could be that the adjuvant activity of RNA renders low doses of antigen effective. Using low doses of antigen might prevent toxic side reactions. Antigens like detoxified toxin $A$ and proteases could be added to the ribosomal preparation or to RNA and DDA to induce effective immunity against pseudomonas infections.

It is quite possible that RNA will appear to be a more potent adjuvant for antigens different from LPS. Part of the LPS molecule, the lipid $A$, functions as an adjuvant for the attached carbohydrate side chains. LPS was shown to induce antibody synthesis in absence of $T$ lymphocytes or macrophages (11). The adjuvant effect of poly (A.U) is probably mediated by the macrophages $(6,10)$. If the same is true for ribosomal RNA, the latter might stimulate more effectively the response to many protein antigens 
than the response to LPS.

However, it is uncertain whether a ribosomal vaccine will be effective in an immunocompromised host. The susceptibility of burn patients and cancer patients for pseudomonas infections is probably associated with their reduced number of leukocytes (18). When the protective effects of ribosomal RNA are mediated by macrophages, a ribosomal vaccine might be much less effective in the leukopenic host than under normal conditions. The required combination of the ribosomal vaccine with DDA presents another difficulty. However, some experience with the application of DDA in cancer patients has been obtained (Dr. J.M.N. Willers, personal communication).

When a comparison between the protective activity and the toxicity of ribosomal vaccines and LPS vaccines is made, the influence of a decreased resistance of the host on the effectivity of the vaccines should be taken into account. From the above mentioned considerations it seems worthwile, however, to set up comparative studies between LPS vaccines and ribosomal vaccines in animal model systems in which the decreased resistance of patients at risk for pseudomonas infections is immitated. Such experiments might enable the decision whether it is worthwile to develop a ribosomal pseudomonas vaccine for the application in clinical situations to prevent patients at risk from this feared bacterial infection.

\section{LITERATURE}

1. Andron, L.A., and H.T. Eigelsbach. 1975. Biochemical and immunological properties of ribonucleic acid-rich extracts from Francisella tularensis. Infect. Immun. 12: 137-142.

2. Araujo, F.G., and J.S. Remington. 1974. Protection against Toxoplasma gondii in mice immunized with toxoplasma cell fractions, RNA and synthetic polyribonucleotides. Immunology 27: $711-721$.

3. Au, C.C., and T.K. Eisenstein. 1981. Nature of cross-protective antigen in subcellular vaccines of Streptococcus pneumoniae. Infect. Immun. 31: 160-168.

4. Baba, T. 1977. Immunogenic activity of a ribosomal fraction obtained from Pasteurella multocida. Infect. Immun. 15: 1-6.

5. Butler, R.C., H. Friedman, S.C. Specter, and T.K. Eisenstein. 1981. Induction of immunoenhancing factors for murine splenocyte cultures by Salmonella typhimurium ribosome and ribonucleic acid extracts. Infect. Immun. 32: 1123-1127.

6. Cone, R.E. 1980. The influence of synthetic homoribopolynucleatide complexes on the immune response. Pharmac. Ther. 8: $321-337$. 
7. Coppel, 5., and G.P. Youmans. 1969. Specificity of acquired resistance produced by immunization with mycobacterial cells and mycobacterial fractions. J. Bacteriol. 97: 114-120.

8. Dussourd d'Hinterland, L., A.M. Pinel, and G. Rey. 1980. Immunological study. Drug Research 30: 132-141.

9. Feit, C., and R.P. Tewari. 1974. Immunogenicity of ribosomal preparations from yeast cells of Histoplasma capsulatum. Infect. Immun. 10: 1091-1097.

10. Johnson, A.G. 1979. Modulation of the immune system by synthetic polynucleotides. Springer Semin. Immunopathol. 2: 149168.

11. Louis, J.A., and P.H. Lambert. 1979. Lipopolysaccharides: from immunostimulation to autoimmunity. Springer Semin. Immunopathol. 2: 215-228.

12. Shepard, C.C., A.S. Youmans, and G.P. Youmans. 1977. Lack of protection afforded by ribonucleic acid preparations from Mycobacterium tuberculosis against Mycobacterium leprae infections in mice. Infect. Immun. 15: 733-736.

13. Tewari, R.P. 1975. Immunization against histoplasmosis, $p$. 411-452. In E. Neter and F. Milgrom (eds.), The immune system and infectious diseases. Fourth International Convocation on Immunology, Buffalo, N.Y., 1974, S. Karger Verlag AG, Basel.

14. Willers, J.M.N., N. Bloksma, C. van der Meer, H. Snippe, H. van Dijk, M.J. de Reuver, and F.M.A. Hofhuis. 1979. Regulation of the immune response by macrophages. Antonie van Leeuwenhoek 45: $41-48$.

15. Youmans, A.S., and G.P. Youmans. 1965. Immunogenic activity of a ribosomal fraction obtained from Mycobacterium tuberculosis. J. Bacteriol. 89: 1291-1298.

16. Youmans, A.S., and G.P. Youmans. 1966. Effect of trypsin and ribonuclease on the immunogenic activity of ribosomes and ribonucleic acid isolated from Mycobacterium tuberculosis. J. Bacteriol. 91: 2146-2153.

17. Youmans, A.S., and G.P. Youmans. 1969. Factors affecting immunogenic activity of mycobacterial ribosomal and ribonucleic acid preparations. J. Bacteriol. 99: 42-50.

18. Young, L.S., and D. Armstrong. 1972. Human immunity to Pseudomonas aeruginasa. I. In vitro interaction of bacteria, polymorphonuclear leukocytes and serum factors. J. Infect. Dis. $126: 257-276$. 


\section{Summary.}

In this thesis the immunological effects of a ribosomal vaccine of Pseudomonas aeruginosa are analyzed.

Fatal pseudamonas infections occur in patients with burns, cancer patients and patients with cystic fibrosis. Attempts have been made to protect burn patients with a pseudomonas vaccine containing lipopolysaccharide (LPS), a cell envelope component of this bacterium. The application of such vaccines to cancer patients was limited, however, because of the toxicity of these vaccines. Since LPS bears the seratype specific 0 antigens, these vaccines had to contain LPS of each of the (frequently occurring) serotypes of $P$. aeruginosa.

From many microorganisms, ribosome-rich preparations were isolated which protected experimental animals, usually mice, against a lethal homologous challenge. Some of the ribosomal vaccines had advantages over more conventional vaccines because of the low toxicity of the ribosomal preparations, or the capacity to induce cross protection against different serotypes of the bacterium. These two properties in particular were attractive for a vaccine of $\underline{P \text {. aeruginosa. }}$

In all studies concerning ribosomal vaccines a central question has been how ribosomes could induce protection. Since immunity results from the host's capacity to recognize the cell surface antigens of the invading microorganism, it is not clear how ribosomes which reside inside the microorganism could stimulate those lymphocytes which bear receptors for the cell envelope antigens. Although the pioneering studies of Youmans and Youmans on the ribosomal vaccine of Mycobacterium tuberculosis demonstrated convincingly that the protective activity of this vaccine was due to ribonucleic acid (RNA), later studies on ribosomal preparations often showed that cell envelope components contaminated the ribosomes and that these surface antigens were responsible for the protective activity. Only in case of a few ribosomal vaccines indications were found that the protective activity was dependent on RNA since the activity of the vaccine was decreased after treatment with ribonuclease (RNase). Most of the RNase sensitive ribosomal vaccines appeared to be prepared from intracellular multiplying microorganisms.

In this thesis the components in the ribosomal vaccine of $P$. aeruginosa which contributed to its protective activity and the mechanism via which the protection was exerted, were analyzed. 
In Chapter 4 the purification and chemical composition of a RNase sensitive ribosomal preparation of $P$. aeruginosa are described. By column chromatography a cell envelope fraction (fraction I) was separated from the ribosomes (fraction II). Subcutaneously injected ribosomes induced some protection against a lethal challenge with $P$. aeruginosa, which was injected intraperitoneally 6 days later. The protection improved when the ribosomes were mixed with the adjuvant dimethyldioctadecylammonium bromide (DDA) prior to injection. The protective activity of the ribosomal vaccine was reduced after treatment with RNase, but not after treatment with proteases. Since the ribosomal vaccine was RNase sensitive, RNA had a function in the protective activity of the vaccine. Two possibilities were considered. RNA might be an adjuvant for contaminating cell surface antigens, or RNA itself might induce protection.

In Chapter 5 the possibility that RNA functioned as an adjuvant is studied by looking for the presence of contaminating cell surface antigens in the ribosomal preparation. With an enzymelinked immunosorbent assay antibodies to LPS could be detected in sera of rabbit and mice which were injected with ribosomes. Several experiments demonstrated that contaminating LPS in the ribosomal preparation contributed to the protective activity by the induction of anti-LPS antibodies. The contribution of another component than LPS to the protective activity of the ribosomes was suggested by the finding that the ribosomes induced higher percentages of survival at certain titers of anti-LPS antibodies than purified LPS. It also appeared that the decreased activity of RNase treated ribosomes could be restored by the addition of synthetic polyadenylic-polyuridylic acid, which is well known for its adjuvant activity. The protective activity and the toxicity of the ribosomes, fraction I and purified LPS were compared. A therapeutic index was calculated which indicates the toxicity of that dose of vaccine that gives a certain degree of protection. According to this criterium, the ribosomes and fraction I were less toxic than purified LPS.

In Chapter 6 the function of RNA in the ribosomal vaccine is clarified. Therefore, the conditions for optimal protection by the ribosomal vaccine were determined first. Intraperitoneal injection of the ribosomes (i.e. via same route as the challenge was given) yielded better results than subcutaneous injection.

The protection appeared as quickly as 1 day after injection of the ribosomes and lasted approximately 9 days. Since no anti-LPS antibodies were found 2 days after treatment with the ribosomes, the early protection could not be ascribed to LPS. The ribosomal vaccine protected mice against a heterologous challenge both 2 and 6 days after injection, while LPS did not induce cross protection. 
Purified ribosomal RNA combined with DOA also protected mice as early as 1 day after injection and the protection was serotypenonspecific. Protein isolated from the ribosomes did not protect mice.

The ribosomal vaccine was immitated by adding small amounts of LPS to RNA + DDA. When LPS was added to RNA + DDA, slightly higher titers of anti-LPS antibodies were induced than by LPS + DDA without RNA, which demonstrated the adjuvant function of RNA. Both RNA and LPS contributed to the protection since higher percentages of survival were induced when LPS was added to RNA + DDA, than by RNA + DDA or LPS + DDA alone. However, LPS contributed only to the protection in case of a homologous challenge. The contribution of RNA to the protective activity appeared also from the finding that preparations containing RNA + DDA and LPS induced higher percentages of survival at certain titers of anti-LPS antibodies, than LPS + DDA without RNA. It was concluded that RNA contributed to the protective activity of the ribosomes in 2 ways. RNA induced nonspecific protection as quickly as 1 day after injection and RNA served as an adjuvant for the LPS which contaminated the ribosomes.

Chapter 7 contains several control experiments which are all designed to establish that the protective activities which were ascribed to RNA could not be due to contaminating LPS or fragments of LPS. Many immunostimulating and immunomodulating activities have been ascribed to LPS, in particular to the lipid $A$ part of this molecule. RNA + DDA did not induce significant anti-LPS antibody titers. With the sensitive Limulus test, LPS could be detected in the ribosomal preparations, but not in the purified RNA.

Inbred mice, which were insensitive for the immunologic activities of LPS were equally well protected by RNA + DDA as LPS sensitive mice. A mutant strain of $P$. aeruginosa which contained a defective LPS without carbohydrate side chains was used to demonstrate that the lipid A part of LPS had no protective activity. The RNA from the mutant and the RNA from the wild type parent strain induced low, but similar protection. RNA isolated from P. aeruginosa protected mice also against challenge with Escherichiacoli and ribosomal RNA's from E. coli and Saccharomyces cerevisiae protected against $P$. aeruginosa challenge. Yeast does not contain LPS. Ribosomal RNA appeared to protect even when it was partially degraded. In contrast, RNA from the E. coli phage MS2 did not protect mice against $\mathbb{P}$. aeruginosa infection.

The experiments clearly demonstrated that the protective activities of RNA were not due to LPS or fragments of LPS in the preparation. Which properties of RNA are decisive for the protective activity of the preparation remained to be elucidated. 
Chapter 8 deals with the question how RNA induced nonspecific protection in the host. Since RNA protected as quickly as one day after injection, the protection was probably not due to antibodies or cellular immunity. This presumption was affirmed by the finding that protection induced by RNA + DDA could not be transferred with serum. The amount of resistance which was induced by RNA + DDA was quantitatively compared with the resistance induced by DDA or physiologic saline by comparing the doses of $P$. aeruginosa, which were lethal, for $50 \%$ of the treated mice $\left(L_{50}\right)$. Intraperitoneal injection of DDA alone increased the resistance of mice for $P$. aeruginosa; addition of RNA to DDA increased the $L_{50} 2.5$ fold more. Injection of RNA + DDA via different routes demonstrated that intraperitoneal administration induced much better protection against an intraperitoneally injected challenge than subcutaneous or intravenous administration. Indications were found that RNA + DDA, but not DDA alone, slightly increased the systemic resistance of the host as well. Intraperitoneal injection of only DDA resulted in the attraction of large numbers of peritoneal cells. After injection of RNA + DDA still higher numbers of peritoneal cells were found, in particular polymorphonuclear leukocytes (PMNLS).

An in vivo phagocytosis system has been developed to find out whether the increased resistance of mice could be ascribed to an increased phagocytic capacity of the host due to the increased number of peritoneal cells, or to an increased activity of phagocytic cells of treated mice. The experiments did not yield support for the latter supposition. A higher number of cells in the peritoneal cavity took up a higher percentage of injected bacteria. However, the uptake of bacteria did not increase proportionally with the number of phagocytes since a lower bacteria to cell ratio also resulted in a lower number of ingested bacteria per cell. A lower number of bacteria per cell seemed to result in a better killing of the ingested bacteria. Since the phagocytosis experiments were performed with opsonized bacteria, it is not sure whether the results apply without modification to the situation in the protection experiments where no anti-LPS antibodies were present. However, the experiments suggested that the resistance induced by RNA + DDA was in part due to the attraction of phagocytic cells.

RNA + DDA did not induce interferon in the peritoneal fluid of mice and injection of interferon did not increase the resistance of mice against $P$. aeruginosa.

The discussion in Chapter 9 is concentrated on the question whether the results of these studies apply to the ribosomal vaccines which have been described in literature. In particular, the question is discussed whether different ribosomal vaccines also might be capable to induce nonspecific resistance, and whether RNA 
in these vaccines might have an adjuvant function. Finally, the perspectives for the application of a ribosomal vaccine of $\underline{p}$. aeruginosa to patients are considered. 


\section{Samenvatting.}

In dit proefschrift wordt de analyse van de immunologische activiteit van een ribosomaal vaccin van Pseudomonas aeruginosa beschreven.

Pseudomonas infecties met dodelijke afloop komen voor bij patiënten met brandwonden, kankerpatiënten en patiënten met cystic fibrosis. Er zijn pogingen gedaan om brandwond patiënten te beschermen met een pseudomonas vaccin dat lipopolysaccharide (LPS), een cel envelop bestanddeel van deze bacterie, bevatte. De toepassingsmogelijkheden voor deze vaccins bij kanker patiënten waren echter beperkt omdat de vaccins toxisch waren. Aangezien LPS de serotype specifieke $D$ antigenen draagt, moesten deze vaccins LPS van alle (veel voorkomende) serotypen van $P$. aeruginosa bevatten.

Uit vele microorganismen zijn ribosoomrijke preparaten geisoleerd die proefdieren, meestal muizen, beschermden tegen een dodelijke, homologe infectie. Sommige ribosomale vaccins hadden voordelen boven de meer conventionele vaccins vanwege de geringe toxiciteit van het ribosomale preparaat of het vermogen om kruisbescherming op te wekken tegen verschillende serotypen van de bacterie. Juist deze twee eigenschappen waren aantrekkelijk voor een vaccin van $P$. aeruginosa.

In alle onderzoeken naar ribosomale vaccins heeft de vraag hoe ribosomen bescherming kanden induceren, centraal gestaan. Aangezien immuniteit het gevolg is van het vermogen van de gastheer om de oppervlakte antigenen van het binnendringende microorganisme te herkennen, is het niet duidelijk hoe ribosomen, die binnen in het microorganisme zitten, die lymphocyten kunnen stimuleren die receptoren dragen voor de cel envelop antigenen.

Hoewel de baanbrekende onderzoeken van Youmans en Youmans naar het ribosomale vaccin van Mycobacterium tuberculosis overtuigend aantoonden dat de beschermende activiteit van dit vaccin te danken was aan ribonucleïne zuur (RNA), toonden latere onderzoeken naar andere ribosomale preparaten vaak aan dat cel envelop bestanddelen de ribosomen verontreinigden en dat deze oppervlakte antigenen verantwoordelijk waren voor de beschermende activiteit. Slechts voor enkele ribosomale vaccins werden aanwijzingen gevonden dat de beschermende activiteit afhankeli.jk was van RNA aangezien de activiteit van het vaccin verminderd was na behandeling met ribonuclease (RNase). De meeste RNase gevoelige ribosomale vaccins bleken bereid te zijn van zich intracellulair vermenigvuldigende microorganismen.

In dit proefschrift is nagegaan welke bestanddelen van het $r$ ibosomale vaccin van $\underline{P}$. aeruginosa bijdroegen tot de beschermencle activiteit van dit vaccin en via welk mechanisme de bescherming 
werd uitgeoefend.

In hoofdatuk 4 worden de zuivering en de chemische samenstelling van een RNase gevoelig ribosomaal preparaat van $P$. aeruginosa beschreven. Door kolom chromatografie werd een cel envelop fractie (fractie I) wan de ribosomen (fractie II) gescheiden. Subcutaan ingespoten ribosomen wekten enige bescherming op in muizen tegen een dodelijke infectie met $P$. aeruginasa die 6 dagen later intraperitoneaal werd ingespoten. De bescherming verbeterde wanneer de ribosomen gemengd werden met het adjuvans dimethyldioctadecylammonium bromide (DDA) voor het inspuiten. De beschermende activiteit van het ribosomale vaccin werd verminderd na behandeling met RNase, maar niet na behandeling met eiwit splitsende enzymen. Aangezien het ribosomale vaccin gevoelig was voor RNase heeft RNA een functie in de beschermende activiteit van het vaccin.

Er zijn twee mogelijkheden overwogen: RNA zou een adjuvans kunnen zijn voor verontreinigende cel oppervlakte antigenen, of RNA zou zelf bescherming kunnen opwekken.

In hoofdstuk 5 is de mogelijkheid dat RNA als een adjuvans functioneerde bestudeerd door te kijken of er verontreinigende cel oppervlakte antigenen in het ribosomale preparaat aanwezig waren. Met een enzyme-linked immunosorbent testsysteem konden antilichamen tegen LPS aangetoond worden in de sera van met ribosomen ingespoten konijnen en muizen. Verschillende experimenten maakten duidelijk dat verontreinigend LPS in het ribosomale preparaat bijdroeg tot de beschermende activiteit doordat het antilichamen tegen LPS opwekte.

De waarneming dat de ribosomen hogere overlevings percentages veroorzaakten bij bepaalde anti-LPS titers dan gezuiverd LPS deed vermoeden dat er nog een ander bestanddeel dan LPS tot de beschermende activiteit van de ribosomen bijdroeg. Verder bleek dat de verminderde activiteit van met RNase behandelde ribosomen hersteld kon worden door toevoeging van synthetisch polyadenosine-polyuridine zuur, warvan bekend is dat het adjuvans activiteit heeft.

De beschemende activiteit en de toxiciteit van de ribosomen, fractie $\mathbb{I}$ en gezuiverd LPS zijn vergeleken. Er werd een therapeutische index berekend die de toxiciteit van die dosis vaccin aangeeft die een bepalde mate van bescherming geeft. Volgens dit criterium waren de ribosomen en fractie I minder taxisch dan gezuiverd LPS.

In hoofdstuk 6 is de functie van RNA in het ribosomale vaccin verduidelijkt. Daartoe werd eerst bepaald onder welke omstandigheden optimale bescherming door het ribosomale vaccin werd opgewekt. Er werden betere resultaten verkregen wanneer de ribosomen intraperitoneal (dat is via dezelfde weg als de infectie) werden toegediend dan wanneer ze subcutaan werden ingespoten. De bescher- 
ming trad al 1 dag na het inspuiten van de ribosomen op en duurde ongeveer 9 dagen. Aangezien er 2 dagen na de behandeling met ribosomen geen anti-LPS antilichamen werden gevonden, kon de vroege bescherming niet aan LPS worden toegeschreven. Zowel 2 als 6 dagen na het inspuiten beschermde het ribosomale vaccin muizen tegen een heterologe infectie terwijl LPS geen kruisbescherming gaf. Gezuiverd ribosomaal RNA dat met DDA gemengd was, beschermde muizen ook al 1 dag na het inspuiten en de bescherming was niet seratype-specifiek. Eiwit dat uit de ribosomen geïsoleerd werd, beschermde de muizen niet.

Het ribosomale vaccin werd geïmmiteerd door kleine hoeveelheden LPS aan DDA + RNA toe te voegen. Wanneer LPS aan DDA + RNA toegevoegd was, werden iets hogere anti-LPS titers opgewekt dan door LPS + DDA zonder RNA, hetgeen de adjuvans functie van RNA aantoonde.

Zowel LPS als RNA droegen bij tot de bescherming want er werden hogere overlevings percentages gevonden wanneer LPS aan RNA + DDA was toegevoegd dan dat er door RNA + DDA of LPS + DDA werden veroorzaakt. LPS droeg echter alleen bij tot de bescherming in geval van een homologe infectie. De bijdrage van RNA aan de beschermende activiteit bleek ook hieruit dat preparaten die RNA + DDA en LPS bevatten bij bepaalde anti-LPS titers hogere overlevings percentages veroorzaakten dan LPS + DDA zonder RNA. Er werd geconcludeerd dat RNA op 2 manieren aan de beschermende activiteit van de ribosomen bijdroeg. RNA wekte al 1 dag na injectie niet-specifieke bescherming op en RNA diende als adjuvans voor het LPS dat de ribosomen verontreinigde.

Hoofdstuk 7 bevat verscheidene controle experimenten die allemaal opgezet zijn om vast te stellen dat de beschermende activiteiten die aan RNA toegeschreven waren, niet te wijten konden zijn aan verontreinigend LPS of LPS-fragmenten. Er zijn veel immunostimulerende en immunomodulerende activiteiten aan L.PS toegeschreven, vooral aan het lipid A deel van dit molecuul.

RNA + DDA wekte geen noemenswaardige anti-LPS titers op. Met de gevoelige Limulus test kon LPS aangetoond worden in het ribosomen preparaat maar niet in het gezuiverde RNA.

Ingeteelde muizen die ongevoelig waren voor de immunalogische activiteiten van LPS werden even goed door RNA + DDA beschermd als muizen die voor LPS gevoelig waren. Een mutant stam van P. aeruginosa die een defect LPS zonder koolhydraat ketens had, werd gebruikt om aan te tonen dat het lipid A deel van LPS geen beschermende activiteit had. Het RNA van de mutant en het RNA van de normale ouder stam wekte lage, maar gelijke bescherming op. RNA dat uit $P$. aeruginosa geīsoleerd was, beschermde muizen onk tegen een Escherichia cali infectie en ribosomale RNA's van E. coli en Saccharomyces cerevisiae beschermden tegen een $P$. aeruginosa infectie. Gist bevat geen LPS. Ribosomal RNA bleek zelfs te 
beschermen wanneer het gedeeltelijk afgebroken was. Het RNA van de E. coli phaag MS2 daarentegen beschermde muizen niet tegen een $P$. aeruginosa infectie.

De experimenten toonden duidelijk aan dat de beschermende activiteiten van RNA niet te wijten waren aan LPS of LPS-fragmenten in het preparat. Welke eigenschappen beslissend zijn voor de beschermende activiteit van een RNA preparat zal echter nog opgehelderd moeten worden.

Hoofdstuk 8 gaat over de vraag hoe RNA niet-specifieke bescherming apwekt bij de gastheer. Aangezien RNA al 1 dag na het inspuiten bescherming gaf, was de bescherming warschijnlijk niet het gevolg van antilichamen of cellulaire immuniteit. Deze veronderstelling werd bevestigd doordat bleek dat de bescherming die door RNA + DDA was opgewekt niet overgedragen kon worden met serum. De nate van weerstand die door RNA + DDA was opgewekt, werd kwantitatief vergeleken met de weerstand die door DDA of physiologisch zout was opgewekt, door de doses van $P$. aeruginosa die dodelijk waren voor 50 procent van de behandelde muizen ( $\left.\overrightarrow{D D}_{50}\right)$ te vergelijken. Het intraperitoneaal inspuiten van alleen DDA verhoogde de weerstand van muizen voor $P$. aeruginosa; toevoeging van RNA aan DDA verhoogde de $L_{50}$ nog 2,5 maal. Door RNA + DDA via verschillende routes in te spuiten, werd aangetoond dat intraperitoneale toediening veel betere bescherming gaf tegen een intraperitoneaal ingespoten infectie dosis dan subcutane of intraveneuze toediening. Er zijn aanwijzingen gevonden dat RNA plus DDA aok de lichaamsweerstand van de gastheer in geringe mate verhoogde, terwijl DDA alléén dat niet deed. Het intraperitoneaal inspuiten van alleen DDA leidde tot de aantrekking van grote aantallen peritoneale cellen. Na het inspuiten van RNA + DDA werden nog grotere aantallen peritoneaal cellen gevonden, vooral polymorphonucleaire leukocyten (PMNLs).

Er is een in vivo phagocytose systeem ontwikkeld om na te gaan of de verhoogde weerstand van muizen toegeschreven kon worden aan een grotere phagocytose capaciteit van de gastheer als gevolg van het toegenomen aantal peritoneaal cellen, of aan een grotere activiteit van phagacyterende cellen van behandelde muizen. De experimenten gaven geen aanwijzing voor de latste veronderstelling. Een groter aantal cellen in de peritoneaal holte nam ook een groter percentage van de ingespoten bacteriën op. De opname van bacterlën hield echter geen gelijke tred met het aantal phagocyten ondat een lagere verhouding van bacteriën tot cellen ook leidde tot een geringer aantal gephagocyteerde bacteriën per cel. Een lager aantal bacteriën per cel leek ook een betere doding van de opgenomen bacteriën tot gevolg te hebben. Het is niet zeker of de resultaten van deze experimenten zonder meer toe te passen zijn op de experimenten warin bescherming bepaald werd, omdat de phagocytose experimenten uitgevoerd werden met geopsoniseerde bacte- 
riën, terwijl bij de beschermings experimenten geen anti-L.PS antilichamen aanwezig waren.

De experimenten ondersteunden echter het idee dat de weerstand die door RNA + DDA was opgewekt gedeeltelijk het gevolg was van het aantrekken van phagocyterende cellen. RNA + DDA wekte geen interferon op in het peritoneaal vocht van muizen en het inspuiten van interferon leidde niet tot verhoging van de weerstand van muizen tegen $\underline{P \text {. aeruginosa. }}$

De discussie in hoofdstuk 9 is geconcentreerd rond de vraag of de resultaten van dit onderzoek van toepassing zijn op de ribosomale vaccins die in de literatuur beschreven zijn. Er is vooral aandacht gegeven aan de vraag of andere ribosomale vaccins ook in staat zouden zijn om niet-specifieke weerstand te induceren, en of RNA in deze vaccins ook een adjuvans functie zou kunnen hebben. Tenslotte is overwogen welke de perspectieven zijn voor de toepassing van een ribosomaal vaccin van $\underline{P}$. aeruginosa bij patiënten. 


\section{Dankwoord}

Dit proefschrift is mede tot stand gekomen dankzij bijdragen van velen in de vorm van deelneming aan het experimentele werk, schenkingen van materiaal, waardevolle adviezen, of het geduldig uittikken van teksten. Graag wil ik ieder van hen hier danken voor hun inzet, aandacht en enthousiasme.

$B i j$ de afzonderlijke hoofdstukken is onze erkentelijkheid aan diegenen, die hun medewerking daaraan verleenden, reeds onder woorden gebracht.

Op deze plaats wil ik graag Prof.Dr. C.P.A. van Boven bedanken voor het bemoedigend enthousiasme warmee hij ons onderzoek begeleid heeft. Onze werkbesprekingen zijn voor mijeen waardevolle stimulans geweest om tot ordening van de resultaten en tot gerichte planning te komen.

Wil Mullers, Paul Lemmens en Mat Volleberg hebben de hier beschreven experimenten uitgevoerd. Zoveel zorg, geduld en weekend-uurtjes hebben zij daaraan besteed, en zozeer hebben zij zich verdiept in de achtergronden van de verschillende werkterreinen dat dit onderzoek éns onderzoek geworden is.

In dit dankwoord wil ik ook graag noemen de adviseurs van ons project, Dr. G. van Dieyen, Prof.Dr. P. van Breda $V_{r}$ iesman en Prof.Dr. R. Zwaal, op wie wij verschillende malen een beroep hebben kunnen doen, en al diegenen die bereid zijn geweest om de manuscripten kritisch door te lezen, in het bijzonder de referenten voor dit proefschrift.

Een woord van dank wil ik hier ook richten tot Fia ClausHahn voor het vele typewerk dat zij zo kundig gedaan heeft, en aan Betty Masaad-Kolfschoten voor haar spontane hulp toen wij in tijdnood zaten.

Tenslotte wil ik mijn dankwoord richten tot diegenen aan wie dit proefschrift is opgedragen. Mijn ouders hebben niet alleen mijn biologie studie mogelijk gemaakt, zij hebben ook na mijn studie hun vertrouwen geschonken in moeizame perioden, mijn plezier gedeeld en zij zijn ingesprongen war nodig.

Richard, veel tijd die aan dit proefschrift besteed werd, had voor ons samen moeten zijn. Toch heb je me steeds aangemoedigd en geholpen on dit werk af te randen. Ik ben je dankbaar dat je er ook plezier in hebt dat het dan toch gelukt is. 


\section{Curriculum vitae}

De schrijfster van dit proefschrift werd op 27 april 1948 geboren in Willemstad (Curaçao). In 1966 werd het eindexamen gymnasium behaald aan het Eerste Vrijzinnig Christelijk Lyceum in Den Haag. De studie in de biologie werd gevolgd aan de Rijksuniversiteit te Utrecht, waar in 1969 het kandidaatsexamen en in 1972 het doctoraal examen werd afgelegd. Van oktober 1972 tot maart 1974 was $z i j$ werkzaam bij de afdeling Cardiobiochemie en Stollingschemie van het Academisch Ziekenhuis te Leiden, waarna zij haar onderzoek continueerde bij de capaciteitsgroep Biochemie van de Medische Faculteit te Maastricht in oprichting. Van 1 februari 1977 tot heden is zij werkzaam bij de capaciteitsgroep Medische Microbiologie aan de Rijksuniversiteit Limburg, waar het in dit proefschrift beschreven onderzoek werd verricht. 